Florida International University FIU Digital Commons

3-11-2011

\title{
Thioredoxin and Jab1 Control Estrogen- and Antiestrogen-Mediated Progression of the Cell Cycle Through p27 Interactions
}

Rosalind B. Penney

Florida International University, rosalind.penney@gmail.com

DOI: 10.25148 /etd.FI11050309

Follow this and additional works at: https://digitalcommons.fiu.edu/etd

\section{Recommended Citation}

Penney, Rosalind B., "Thioredoxin and Jab1 Control Estrogen- and Antiestrogen-Mediated Progression of the Cell Cycle Through p27 Interactions" (2011). FIU Electronic Theses and Dissertations. 380.

https://digitalcommons.fiu.edu/etd/380 


\section{FLORIDA INTERNATIONAL UNIVERSITY \\ Miami, Florida}

\section{THIOREDOXIN AND JAB1 CONTROL ESTROGEN- AND ANTIESTROGEN- MEDIATED PROGRESSION OF THE CELL CYCLE THROUGH P27 INTERACTIONS}

A dissertation submitted in partial fulfillment of the requirements for the degree of DOCTOR OF PHILOSOPHY

in

PUBLIC HEALTH

by

Rosalind Brigham Penney

2011 
To: Interim Dean Michele Ciccazzo

Robert Stempel College of Public Health and Social Work

This dissertation, written by Rosalind Brigham Penney, and entitled Thioredoxin and Jab1 Control Estrogen- and Antiestrogen-Mediated Progression of the Cell Cycle through p27 Interactions, having been approved in respect to style and intellectual content, is referred to you for judgment.

We have read this dissertation and recommend that it be approved.

$\begin{array}{r}\text { Alejandro Barbieri } \\ \hline \text { Quentin Felty } \\ \hline \text { Jai Parkash } \\ \hline \text { Deodutta Roy, Major Professor }\end{array}$

Date of Defense: March 11, 2011

The dissertation of Rosalind Brigham Penney is approved.

Interim Dean Michele Ciccazzo

Robert Stempel College of Public Health and Social Work

Interim Dean Kevin O'Shea

University Graduate School

Florida International University, 2011 


\section{DEDICATION}

I dedicate this dissertation to my wonderful family. Particularly to my loving and

understanding husband, Allen, who has put up with these many years of research and loves me still, and to my parents, Robert and Deirdre for their constant love and support. It is through them that I find my strength.

"In time of test, family is best." - Burmese Proverb 


\section{ACKNOWLEDGMENTS}

I gratefully acknowledge the support and encouragement of my major professor, Dr. Deodutta Roy. I also wish to thank the members of my committee, Dr. Quentin Felty, Dr. Jai Parkash, and Dr. Alejandro Barbieri for their valuable advice and time commitment. My heartfelt thanks go to Dr. Robert and Ms Patricia Brigham for their time and effort in editing parts of this document, as well as for their endless support. Finally, I would like to thank my fellow graduate students, who provided invaluable support and suggestions throughout this process. 


\title{
ABSTRACT OF THE DISSERTATION \\ THIOREDOXIN AND JAB1 CONTROL ESTROGEN- AND ANTIESTROGEN- MEDIATED PROGRESSION OF THE CELL CYCLE THROUGH P27 INTERACTIONS
}

\author{
by \\ Rosalind Brigham Penney \\ Florida International University, 2011 \\ Miami, Florida \\ Professor Deodutta Roy, Major Professor
}

A major problem with breast cancer treatment is the prevalence of antiestrogen resistance, be it de novo or acquired after continued use. Many of the underlying mechanisms of antiestrogen resistance are not clear, although estrogen receptor-mediated actions have been identified as a pathway that is blocked by antiestrogens. Selective estrogen receptor modulators (SERMs), such as tamoxifen, are capable of producing reactive oxygen species (ROS) through metabolic activation, and these ROS, at high levels, can induce irreversible growth arrest that is similar to the growth arrest incurred by SERMs. This suggests that SERM-mediated growth arrest may also be through ROS accumulation. Breast cancer receiving long-term antiestrogen treatment appears to adapt to this increased, persistent level of ROS. This, in turn, leads to the disruption of reversible redox signaling that involves redox-sensitive phosphatases and protein kinases and transcription factors. This has downstream consequences for apoptosis, cell cycle progression, and cell metabolism. For this dissertation, we explored if altering the ROS formed by tamoxifen also alters sensitivity of the drug in resistant cells. We explored an 
association with a thioredoxin/Jab1/p27 pathway, and a possible role of dysregulation of thioredoxin-mediated redox regulation contributing to the development of antiestrogen resistance in breast cancer. We used standard laboratory techniques to perform proteomic assays that showed cell proliferation, protein concentrations, redox states, and proteinprotein interactions. We found that increasing thioredoxin reductase levels, and thus increasing the amount of reduced thioredoxin, increased tamoxifen sensitivity in previously resistant cells, as well as altered estrogen and tamoxifen-induced ROS. We also found that decreasing levels of Jab1 protein also increased tamoxifen sensitivity, and that the downstream effects showed a decrease p27 phosphorylation in both cases. We conclude that the chronic use of tamoxifen can lead to an increase in ROS that alters cell signaling and causing cell growth in the presence of tamoxifen, and that this resistant cell growth can be reversed with an alteration to the thioredoxin/Jab1 pathway. 


\section{TABLE OF CONTENTS}

I. INTRODUCTION 1

II. LITERATURE REVIEW: THIOREDOXIN, CHANGES IN REDOX 4 STATE OF CELLS AND A NEW PERSPECTIVE IN AN UNDERSTANDING OF TAMOXIFEN RESISTANCE IN BREAST CANCER TREATMENT

Abstract

1. Introduction

2. Mechanisms of estrogen actions in breast cancer

3. Actions of endocrine therapeutic agents 10

4. Overview of existing paradigms of antiestrogen resistance 15

5. Redox signaling and antiestrogen resistance 18

Redox state of cells $\quad 18$

Reactive oxygen species as signaling molecules 21

$\begin{array}{ll}\text { Redox signaling } & 23\end{array}$

Redox regulation of protein tyrosine phosphatases/kinases 25

Redox regulation of transcription factors $\quad 27$

Thioredoxin system and redox regulation 28

Trx family and ROS $\quad 33$

Redox regulation of proteins by thioredoxin $\quad 36$

$\begin{array}{ll}\text { Thioredoxin interactions with other proteins } & 37\end{array}$

Background to a new paradigm for antiestrogen resistance $\quad 42$

Thioredoxin and cell cycle progression/arrest 42

p27 44

Jab1 47

Thioredoxin and its proposed role in antiestrogen resistance $\quad 50$

Jab1 and a possible interaction with thioredoxin 52

PTPs and thioredoxin $\quad 53$

6. Summary

55

Acknowledgments $\quad 56$

Reference List $\quad 56$

$\begin{array}{lr}\text { Figures } & 81\end{array}$

III. INCREASING THIOREDOXIN REDUCTASE EXPRESSION OR 83 REDUCING JAB1 EXPRESSION REDUCES CELL PROLIFERATION IN TAMOXIFEN-TREATED LCC2 CELLS

Abstract

Introduction

Materials and methods $\quad 86$

Results

Discussion 
$\begin{array}{ll}\text { Reference List } & 97\end{array}$

$\begin{array}{ll}\text { Figures } & 99\end{array}$

IV. INCREASED THIOREDOXIN REDUCTASE OR DECREASED 107

JAB1 LEADS TO DECREASED GROWTH IN BREAST CANCER CELLS UPON ESTROGEN TREATMENT THROUGH DECREASED AKT AND P27 PHOSPHORYLATION

Abstract

Introduction

108

Materials and methods

110

Results

115

Discussion

Reference List

123

Figures

V. CONCLUSION

134

Directions for future research 


\section{LIST OF FIGURES}

FIGURE

PAGE

1-LR Estrogen actions in breast cancer $\quad 81$

2-LR $\quad$ Sources of oxidants and actions of antioxidants $\quad 81$

3-LR Cellular dose/response to oxidants $\quad 82$

4-LR Thioredoxin Oxidation and Reduction 82

5-LR Proposed role of thioredoxin in AE resistance $\quad 83$

1-LCC2 Upregulation of cellular and mitochondrial thioredoxin 99 reductase reduced the formation of anchorage-independent colonies in tamoxifen-resistant cells. Downregulation of Jab1 reduced the formation of anchorage-independent colonies in tamoxifen-treated tamoxifen-resistant LCC2 cells.

2-LCC2 Upregulation of cellular and mitochondrial thioredoxin reductase decreased DNA synthesis in tamoxifen-treated tamoxifen-resistant LCC2 cells. Downregulation of Jab1 also decreases DNA synthesis in tamoxifen-treated tamoxifenresistant LCC2 cells.

3-LCC2 Upregulation of TrxR2 and TrxR2 $\backslash$ with plasmid overexpression or isothiocyanate treatment increases Trx 2 and Trx expression in addition to TrxR2 and TrxR expression in LCC 2 cells.

4-LCC2 Thioredoxin oxidation in tamoxifen resistant cells may be reversible.

5-LCC2 Upregulation of cellular and mitochondrial thioredoxin reductase increase Jab1/Trx binding and decrease Jab1 p27 binding in tamoxifen-treated tamoxifen-resistant LCC2 cells.

6-LCC2 Overexpression of TrxR1 through erucin treatment decreases p27 phosphorylation at T157 and T187. Underexpression of Jab1 decreases p27 phosphorylation at T187.

1-MCF7 Upregulation of cellular and mitochondrial thioredoxin reductase 126 reduces the formation of anchorage-independent colonies in estrogen-treated ER+ breast cancer epithelial cells.

Downregulation of Jab1 reduced the formation of anchorage- 
independent colonies in estrogen-treated ER+ breast cancer epithelial cells.

2-MCF7 Upregulation of cellular and mitochondrial thioredoxin reductase decreased DNA synthesis in estrogen-treated MCF-7 cells. Downregulation of Jab1 decreased DNA synthesis in estrogentreated MCF-7 cells.

3-MCF7 Estrogen increases oxidative state of MCF-7 cells and leads to an increase in oxidation of Trx1.

4-MCF7 Oxidation of PTEN by estradiol is reversed with overexpression of thioredoxin reductase.

5-MCF7 Overexpression of thioredoxin reductase and underexpression of Jab1 decreases Akt phosphorylation at Ser473 in estrogen-treated MCF-7 cells.

6-MCF7 Overexpression of TrxR1 through erucin treatment decreases p27 phosphorylation at T157. Underexpression of Jab1 decreases p27 phosphorylation at T157. 


\section{LIST OF ACRONYMS}

\begin{tabular}{|c|c|}
\hline $\mathrm{AE}$ & Antiestrogen \\
\hline AI & Aromatase inhibitor \\
\hline ASK1 & Apoptosis signal-regulating kinase 1 \\
\hline $\mathrm{Cdk}$ & Cyclin-dependent kinase \\
\hline $\mathrm{CIP} / \mathrm{KIP}$ & Cdk inhibiting and kinase inhibiting proteins \\
\hline Cys & Cysteine \\
\hline$\Delta \psi m$ & Mitochondrial membrane potential \\
\hline E1 & Estrone \\
\hline $\mathrm{E} 2$ & $17 \beta$-estradiol \\
\hline EGFR & Epidermal growth factor receptor \\
\hline ER & Estrogen receptor \\
\hline $\mathrm{H}_{2} \mathrm{O}_{2}$ & Hydrogen peroxide \\
\hline Jab1 & Jun activation domain-binding protein 1 \\
\hline MAPK & mitogen activating protein kinase \\
\hline MIF & Macrophage migration inhibitory factor \\
\hline Nrf2 & Nuclear factor erythroid 2-related factor 2 \\
\hline $\mathrm{O}_{2}{ }^{--}$ & Superoxide \\
\hline $\mathrm{OH}^{-}$ & Hydroxyl radical \\
\hline $\mathrm{ONOO}^{-}$ & Peroxynitrite \\
\hline PTK & Protein tyrosine kinase \\
\hline PTP & Protein tyrosine phosphatase \\
\hline ROS & Reactive oxygen species \\
\hline
\end{tabular}




$\begin{array}{ll}\text { RTK } & \text { Receptor Tyrosine Kinase } \\ \text { SERM } & \text { Selective estrogen receptor modulator } \\ \text { SOD } & \text { Superoxide dismutase } \\ \text { Tam } & \text { Tamoxifen } \\ \text { Trx } & \text { Thioredoxin } \\ \text { TrxR } & \text { Thioredoxin reductase } \\ \text { Txnip } & \text { Thioredoxin inhibiting protein }\end{array}$




\section{INTRODUCTION}

It is estimated that 1.2 million people will be diagnosed with breast cancer every year. Through research on hormone replacement therapies and estrogen-receptor (ER)-based therapies, estrogen has been found to be involved in the development of breast cancer. ${ }^{1}$ Currently, there are several options for the treatment of breast cancer, including surgery, radiation, chemotherapy, and hormonal therapy. Antiestrogens (AEs) are a known adjunctive therapy, and are used as a preventive measure as well. The most common form of hormonal therapy has been, for many years, selective estrogen receptor modulators (SERMs) such as tamoxifen, raloxifene, and toremifene. ${ }^{2}$

A major problem with the use of antiestrogens (AE) is the prevalence of resistance, either at the outset of treatment or after continued use. The underlying mechanisms of antiestrogen resistance remain unclear. ER-mediated actions were identified initially as a pathway that was blocked in AE-treated cells, and inhibition of this pathway has been shown to cause permanent growth arrest/cell death. Reactive oxygen species (ROS) are an outcome of oxidative processes and can induce an irreversible growth arrest similar to selective estrogen receptor modulator (SERM) antiestrogens. SERMs are capable of producing ROS through their metabolic activation. These findings suggest that SERMs may mediate growth arrest by a mechanism involving ROS accumulation.

The antioxidant thioredoxin may have a role in antiestrogen resistance in breast cancer. As cells are chronically exposed to ROS from long-term tamoxifen treatment, they can 
adapt to this increasing level of ROS and oxidative stress. This can lead to oxidation of certain cellular antioxidant systems, such as thioredoxin, causing them to become inactive. The inactivation of the thioredoxin antioxidant family can then affect other proteins such as PTPs or Jab1, or lead to the continued activation of cell signaling pathways such as MAPKs (mitogen activating protein kinases), leading to the activation of transcription factors such as $\mathrm{AP}-1$ or NF-kB and subsequent cell proliferation.

We hypothesized that antiestrogen generated ROS, through the oxidization of Trx, increases the amount of free Jab1 accessible to bind to p27. This, in turn, promotes the loss of the inhibitory functions of p27, leading to antiestrogen resistance. Our goal, then, was to investigate whether reducing oxidized Trx in antiestrogen-resistant breast cancer cells restores the anti-proliferative function of antiestrogen treatments through restoring the Trx to compete for Jab1 binding, and thus renewing the inhibitive quality of p27.

The following specific aims were set up to test the hypothesis:

Aim 1: To investigate whether reducing oxidized Trx restores the anti-proliferative action of antiestrogen by: (i) determining if reducing Trx using ROS inhibitors and/or ROS detoxifying enzymes and/or an overexpression of Trx reductase restores the antiproliferative effect of antiestrogens by increasing Trx binding with Jab-1 and renewing the inhibitory function of p27; and (ii) investigating whether a persistent increase in oxidative stress leads to antiestrogen resistance in previously sensitive breast cancer cells through downregulating Trx reductase, upregulating Jab-1, and thus impairing the p27 inhibitory function. 
Aim 2: To determine the molecular mechanisms by which a pro-oxidative state may promote the oxidation/inhibition of Trx, p27 inactivation by Jab-1, and cell cycle progression by investigating whether redox signaling pathways in antiestrogen resistant cells can either directly or indirectly regulate levels of oxidized Trx and p27 in antiestrogen-resistant breast cancer cells.

Aim 3: Testing of the hypothesis using in vivo conditions by investigating whether ROS inhibitors and/or Trx reductase can cooperate with antiestrogens to inhibit the proliferation of estrogen-independent, antiestrogen-resistant breast cancer cells in a 3dimensional culture.

After beginning experiments, we chose to alter Aim 1 (ii) and not to perform Aim 3. We wanted instead to explore the role of the protein tyrosine phosphatase PTEN in estrogenmediated oxidative stress in breast cancer cells, as PTP alteration may also occur due to increased estrogen. We thought it important to explore the cell signaling pathways, namely those associated with thioredoxin/Jab1 and p27, which occur due to estrogen exposure in ER+ cells, as well as those initiated by the treatments. Both estrogen and tamoxifen have been shown to increase levels of ROS in breast cancer cells, ${ }^{3}$ and thus our findings may be applied to the formation of tamoxifen resistance through increased ROS. Our specific aim was to show the alteration of ROS through the thioredoxin/Jab1 pathway and the effect on p27 phosphorylation in MCF-7 cells. 


\title{
II. LITERATURE REVIEW:
}

\section{THIOREDOXIN, CHANGES IN REDOX STATE OF CELLS AND A NEW PERSPECTIVE IN AN UNDERSTANDING OF TAMOXIFEN RESISTANCE IN BREAST CANCER TREATMENT}

\begin{abstract}
A major problem with the use of antiestrogens (AE) is the prevalence of resistance, either at the outset of treatment or after continued use. The underlying mechanisms of AE resistance remain unclear. Estrogen receptor (ER)-mediated actions were identified initially as a pathway that was blocked in AE-treated cells, and inhibition of this pathway has been shown to cause permanent growth arrest/cell death. Reactive oxygen species (ROS), a byproduct of oxidative processes, can induce an irreversible growth arrest similar to selective estrogen receptor modulator (SERM) antiestrogens. SERMs are capable of producing ROS through their metabolic activation. These findings suggest that SERMs may mediate growth arrest by a mechanism involving ROS accumulation.
\end{abstract}

Breast cancer cells have higher amounts of ROS than normal cells, and chronic treatment with tamoxifen or fulvestrant adds additional ROS. Breast cancer cells receiving longterm antiestrogen treatment appear to adapt to this increased, persistent level of ROS. This, in turn, leads to the disruption of reversible redox signaling that involves redoxsensitive phosphatases and protein kinases such as ERK and AKT, and also involves transcription factors such as AP-1 and NF- $\mathrm{BB}$. This has downstream consequences for apoptosis, cell cycle progression, and cell metabolism. This review 
discusses concepts in support of a possible role of dysregulation of thioredoxin-mediated redox regulation contributing to the development of $\mathrm{AE}$ resistance in breast cancer. The inactivation of the thioredoxin antioxidant family can disrupt reversible redox signaling pathways and cause the cell to become unresponsive to AE-induced cell cycle arrest or cell death, or lead to the continued activation of cell signaling pathways such as MAPKs, leading to the activation of transcription factors and subsequent cell proliferation.

\section{Introduction}

Through research on hormone contraception, postmenopausal hormonal therapies and estrogen-receptor (ER)-based endocrine therapies, we know that estrogen is a major risk

factor of breast cancer. ${ }^{1,4-14}$ Therefore, preventive strategies are predominantly restricted to antiestrogenic (AE) stimulation of its cognate receptor. The ER-based endocrine therapy includes selective estrogen receptor modulators (SERMs) (tamoxifen, raloxifene [Evista], and toremifene [Fareston]), pure antiestrogens (fulvestrant [Faslodex]), luteinizing hormone-releasing hormone agonists (leuprolide, goserelin [Zoladex]), and aromatase inhibitors (anastrozole [Arimidex], letrozole [Femara], exemestane $\left[\right.$ Aromasin]). ${ }^{2}$ Currently, there are several other options for the treatment of breast cancer, including surgery, radiation, and chemotherapy. Endocrine therapy is an effective treatment strategy for breast cancer and is responsible for a significant reduction in breast cancer mortality. However, while approximately $70 \%$ of newly diagnosed breast cancers express the estrogen receptor (ER), up to $50 \%$ of these do not respond to the above endocrine therapeutic agents ${ }^{15-17}$. Furthermore, after a certain period of treatment with antiestrogens or aromatase inhibitors, breast tumors can become resistant to these agents. 
Along with the acquired form of resistance, there is also "de novo," or primary, resistance. The mechanisms of acquired $\mathrm{AE}$ and de novo resistances are not completely understood, and are likely quite complex. Tamoxifen and other AEs are thought to prevent cancer through their actions at the ER. These compounds also scavenge free radicals and block the metabolism and redox cycling of estrogen, so other mechanisms of action cannot be ruled out. ${ }^{18}$ Another scenario is that the ER is functional and driving estrogen-dependent processes with the exception of growth. This would indicate that other independent pathways are stimulating growth. In this case, estrogen-deprivation therapies would reduce expression of classically estrogen-regulated genes, but not those associated with cellular proliferation. This phenotype has been observed in ER-positive tumors treated with neoadjuvant letrozole. ${ }^{19,20}$

These findings suggest that nuclear ER genomic signaling pathways do not solely regulate estrogen-dependent growth of cells. Both estrogen and AEs cause the production of ROS. ${ }^{3,9}$ As a known signaling molecule and second messenger, ROS has the potential to make dramatic changes in cell cycle progression. While there are systems in cells to counteract this production, the chronic exposure of cells to low to medium levels of oxidants can lead to a shift in the "normal" environment of the cell. In the pro-oxidant state of cells (i.e., high oxidative stress), the balance of thioredoxin (Trx) status is shifted towards the oxidized form of Trx. There are several studies showing indirect evidences in support of the concept that high expression of oxidized Trx may be associated with drug resistance in primary breast cancer. ${ }^{21,22}$ In this review, we will discuss the role of Trx in $\mathrm{AE}$ resistance in breast cancer and recent studies in this area. First, estrogen's and AE's 
actions are reviewed in brief. Then the role of AE-induced generation of oxidants and emerging data on the ability of AE-induced RO/NS to modify Trx-mediated redoxsensitive signal transduction pathways are discussed.

\section{Mechanisms of estrogen actions in breast cancer}

In order to understand the $\mathrm{AE}$ actions in cells, it is important that we understand estrogen actions in normal breast epithelial and cancer cells. Therefore, we have briefly summarized here estrogen actions. It is widely recognized that estrogen promotes preneoplastic and malignant growth via interaction with estrogen receptors alpha and beta (ER $\alpha$ and $E R \beta)$. This interaction then can lead to transcription either by directly binding to estrogen response elements, or through non-genomic pathways. The non-genomic action of estrogen very often includes ligand-binding to the ER at the plasma membrane, and leads to the activation of signaling pathways such as MAPK, protein kinases A and $\mathrm{C}$, and calcium pathways, ${ }^{23}$ initiating a cell signaling sequence that leads to proliferation. Another non-classical action of the ER is its direct binding to AP-1. When the DNA binding domain of mouse ER $\alpha$ is mutated, there is an interaction with Jun, an AP-1 coactivator. ${ }^{24}$ In MCF-7 breast cancer cells, estrogen has been demonstrated to activate the growth regulatory gene cyclin D1 by 2 to 3 fold. It has also been seen that estrogen can upregulate c-jun and c-fos in this cell line, which can combine to bind and activate AP-1 sites on DNA. ${ }^{25,26}$ Other studies, however, present that estrogen creates increased AP-1 activity without the expected increase in c-fos and c-jun synthesis, implying that estrogen activates, but does not synthesize, other proteins that activate AP-1. ${ }^{27}$ Estrogen 
activates transcription factors such as NF- $\kappa \mathrm{B}$, and CREB. Estrogen actions through ER have been extensively reviewed; therefore we have limited our discussion in this area.

More recently, a new mechanism of estrogen action in breast cancer cells has emerged. Estrogen produces intracellular ROS rapidly, which can lead to cell signaling, and oxidants contribute to the growth of estrogen-dependent breast cancer cells. ${ }^{28} 29$ Importantly, the ROS produced in breast cancer as a result of estrogen stimulation does not require estrogen receptors, as the ER-negative cell line MDA-MB 468 produces a similar amount of ROS as the ER-positive cell lines MCF-7, T47D, and ZR75. ${ }^{9}$ It has also been demonstrated that estrogen is able to stimulate growth in the non-ERexpressing cell line HEK293. This ER-independent growth shows that other factors are involved in estrogen-stimulated cell growth, and further studies have implicated mitochondrial ROS formation. ${ }^{30}$ Free radical generation by estrogen has been demonstrated, as has the instigation of redox cycling in both stilbene and catechol estrogens. The damage that can occur due to these estrogen-induced free radicals can lead to DNA strand breakage, 8-hydroxylation of purine bases of DNA, and lipid hydroperoxide-mediated DNA modification. ${ }^{9,}{ }^{12,31}$ Redox cycling of estrogen is a delayed event, because estrogen has to be first metabolized to catechol estrogens to participate in redox reactions. In the cells of target tissues, there has to be free catechol estrogen available to participate in redox reactions. Hydroxylated estrogens do not cause the rapid production of ROS intracellularly through redox cycling, as the metabolites and the adducts of these hydroxylated estrogens are not seen immediately after E2 treatment, while the ROS are. ${ }^{9}$ 
There is evidence in support of the concept that: i) Physiologically achievable 17ßestradiol (E2) concentration of $1 \mathrm{nM}$, which corresponds to the estrogenic menstrual peak, induces rapid formation of mitochondrial ROS in MCF-7 cells. We and others have also shown similar findings in MDA-MB-231 and other ER-negative cells, indicating that ER status is not relevant to this effect. ${ }^{32-34}$ ii) Overexpression of biological ROS scavengers (e.g., MnSOD and catalase), treatments of cells with chemical antioxidants, (e.g., N-acetylcysteine and ebselen) or silencing of mitochondrial biogenesis (source of ROS), inhibits estrogen-induced colony formation in MCF-7 cells. This suggests that estrogen-induced mitochondrial ROS promote in vitro tumor formation in breast cancer cells. iii) The expression of early cell cycle genes (such as cyclin D1, D3, E1, E2, and B2) as well as PCNA, PRC1, and bcl2 that are normally induced by estrogen, were inhibited by the addition of mitochondrial blockers. This is important because neither antioxidants nor mitochondrial blockers have presented with ER binding. As such, it suggests that the transition from $\mathrm{G} 1$ to $\mathrm{S}$ in estrogen-exposed cells is modulated by mitochondrial ROS. ${ }^{35}$ Figure 1-LR shows the different pathways of estrogen-mediated cell growth.

Recently estrogens have been implicated as antioxidants through scavenging lipid peroxyl radicals and thus interrupting lipid peroxidation. They also scavenge hydroxyl radicals at higher levels, and can inhibit superoxide radical generation. ${ }^{36}$ Estrogen inhibits the apoptotic oxidative effects of TNF- $\alpha$ (ROS generation, lipid peroxidation, antioxidant enzyme consumption and disruption of mitochondrial membrane potential). ${ }^{37}$ Estrogens are phenolic chemicals. In the presence of an oxidant-generating environment, 
the phenolic hydroxyl group present at the $\mathrm{C} 3$ position of the A ring of estrogens or catechol estrogens can readily accept electrons, and can become oxidized by either accepting these electrons or losing a proton. This can explain the anti-oxidative function of estrogens. ${ }^{31,38,39}$ There are structural similarities between estrogens and Vitamin E in terms of an aromatic ring. A hydroxyl group in both compounds donate a hydrogen atom to reduce free radicals, which allows estrogens and vitamin $\mathrm{E}$ to act in an antioxidant way in the presence of an oxidative environment. Additionally, it has been suggested that estrogen exerts its antioxidative actions through suppressing inflammatory cytokines or modulating antioxidant enzyme status. ${ }^{40,41}$ In support, there is a link between cell viability that is enhanced by the estrogen receptor and thioredoxin expression. This was shown through inhibiting thioredoxin reductase, and noting a reduction in cytoprotection. ${ }^{42}$ This was also explored in bovine aortic endothelial cells, and found that $17 \beta$-estradiol increased the levels of thioredoxin, glutaredoxin, and thioredoxin reductase. Tamoxifen treatment inhibited the induction of these three proteins. ${ }^{43}$

In summary, these studies suggest that estrogen-generated oxidants, together with an estrogen-driven increase in epithelial cell proliferation, may initiate and promote neoplastic lesions in estrogen-sensitive tissues. As such, the importance of the ROS generated by estrogen cannot be ignored when exploring antiestrogen resistance.

\section{Actions of endocrine therapeutic agents}

The actions of endocrine therapy are primarily based on either lowering ER function or reducing the levels of circulating free estrogens. Molecular mechanisms of actions of 
individual endocrine therapeutic agents have been extensively reviewed; therefore we have limited our discussion in this area here. Tamoxifen is one of the effective endocrine therapies for breast cancer that promotes a conformational change in the estrogen receptors that effectively blocks coactivator binding, and restricts AF-2 (a protein found in early G1 phase cells)-induced transcription. However, it also acts as an agonist on AF1-dependent genes. ${ }^{26}$ As AF-1 and AF-2 are tissue specific, ${ }^{44}$ this could explain the tissue-dependent dual antagonistic/agonistic roles of tamoxifen ${ }^{26}$ While tamoxifen is a breast cancer antagonist, it also has agonistic qualities in the uterus and bone. It is through this duality that tamoxifen is called a selective estrogen receptor modulator (SERM) ${ }^{45}$ Tamoxifen's role as a non-steroidal estrogen antagonist allows it to inhibit proliferation and induce apoptosis of breast cancer cells. ${ }^{46}$ This was demonstrated with the use of ER-positive MCF-7 cells and ER-negative MDA MB-231 cells in which tamoxifen (5-7uM) induced rapid (within 60 minutes) breast cancer cell death. ${ }^{3}$ It has been noted that tamoxifen will act as an estrogen agonist in the non-genomic, membranebound ER pathways, where ER activates kinases such as Src, PI3K, MAPK, EGFR (epidermal growth factor receptor) and ErbB2. The levels of these kinases play a role in this, however. Thus if cancer cells express low levels of EGFR and ErbB2, for example, the membrane ER function, and thus tamoxifen's agonistic effects, on these tyrosine kinase receptors may be slight. ${ }^{26}$

Tamoxifen has also been shown to be a potent antioxidant in certain cells. While its actions in breast cancer cells lead to cell death, it offers neuroprotection after middle cerebral artery occlusion. Tamoxifen effects in this disease are thought to be through 
agonistic actions on ER and antioxidant actions. Just as estrogen can be an antioxidant to low-density lipoproteins (LDLs), tamoxifen and raloxifene are also able to decrease the oxidation of LDLs. ${ }^{18}$ A similar antioxidant effect on LDLs is seen in human umbilical vein endothelial cells. ${ }^{47}$ Tamoxifen also has presented with antioxidant qualities in myocardial ischemia-reperfusion $(\mathrm{I} / \mathrm{R})$ injury. In rats with induced $\mathrm{I} / \mathrm{R}$ injury there was a significant decrease in glutathione and glutathione peroxidase as compared to rats that also had tamoxifen treatment. ${ }^{48}$ With focal cerebral ischemia, the antioxidant effects of tamoxifen may be due to an increase in manganese superoxide dismutase (MnSOD) levels and a subsequent decrease in the activation of kinases and caspase-3, which are downstream of superoxide production. ${ }^{49}$ In the uterus, tamoxifen increases superoxide dismutase (SOD) activity, and decrease NADPH oxidase (a superoxide generator) activity. ${ }^{50}$ Tamoxifen is derived from the estrogen-mimetic hydrocarbon stilbene, and the stilbene structure can act as a substitute for estradiol. In the presence of an oxidant generating environment, tamoxifen can readily react quantitatively with hydroxyl free radicals, and this can explain the anti-oxidative function of tamoxifen. ${ }^{51}$

When tamoxifen is present alone in cells it can lead to the formation of ROS in breast cancer cells. While tamoxifen induces breast cancer cell death, it also results in an increase of ROS production by 1.7 to 2.0 fold. Tamoxifen has rapid non-genomic effects such as releasing cytochrome $\mathrm{c}$, decreasing mitochondrial membrane potential $(\Delta \psi m)$, and increasing ROS. ${ }^{52}$ Tamoxifen also is known to inhibit the mitochondrial electron transport chain. ${ }^{53}$ Studies have shown that tamoxifen decreases the $\Delta \psi m$ and rapidly releases mitochondrial cytochrome $c$ in p53-negative breast cancers. ${ }^{3,54}$ This occurs 
through the stimulation of mitochondrial nitric oxide synthase and the ensuing decrease in mitochondrial respiration and release of cytochrome $c{ }^{55}$ This release is accompanied by ROS production, leading to oxidative stress in the cell. ${ }^{28,29,56}$ This oxidative stress may then lead to apoptosis, as it has been suggested that this disruption of the function of the mitochondria may play an important role in tamoxifen's fast death response. ${ }^{52}$ However when inhibitors of complexes I, II, or III are added to HepG2 cells, the levels of ROS and apoptosis that are typically induced by tamoxifen are not altered significantly. This is also true when the mitochondrial uncoupler carbonylcyanide-p(triflouromethyoxy)phenylhydrazone (FCCP) is used. ${ }^{57}$ A novel use for tamoxifen utilizing its ability to produce ROS was seen when tamoxifen was used as a carrier for iron (ferrocene). When tamoxifen delivered the metal to tumor cells, the iron interacted with the hydrogen peroxide already present, and resulted in large amounts of hydroxyl ions and hydroxyl radicals, which then induced apoptosis in the cell. In this way the high amount of hydrogen peroxide in tumor cells was used as a prodrug for treatment. ${ }^{58}$

Another SERM that works in a similar way to tamoxifen is raloxifene. Raloxifene also binds to the estrogen receptor, and its affinity for it is similar to that of estrogen. While the bond with the ER creates a change in the special configuration of the ER that prohibits both activation of and binding of estrogen to the ER, it also contains a peculiarity in its binding that allows it to block AF-2 interactions, which some say is the key to its ability to be an estrogen antagonist in both breast and uterine tissues. This interaction of raloxifene and the ER are quite different in bone and non-reproductive tissues where it acts as an estrogen agonist through the use of helper/adapter proteins. ${ }^{59}$ 
A more "pure" estrogen antagonist is ICI 182780, or fulvestrant. Fulvestrant acts in three ways on the ER. First, in binding to the ER, it impairs the ability of the ER to dimerize as well as its ability to move into the nucleus. It also disables the ER activation functions of AF1 and AF2, which recruit coactivators and other necessary proteins to the transcriptional complex, both of which are necessary for estrogen agonistic activity. And lastly, when fulvestrant binds to the ER, the complex becomes unstable, which leads to an accelerated degradation of the ER protein, though not of ER mRNA. ${ }^{60}$

The prototype SERM (tamoxifen) and its derivatives (toremifene, droloxifene, and, idoxifene), the second-generation SERM raloxifene, the third-generation SERM arzoxifene, and the fourth-generation SERM alcolbifene undergo metabolic activation and their metabolites are more capable of participating in redox reactions. ${ }^{61,62}$

The ER-mediated actions were identified initially as a pathway blocked in AE-treated cells, and inhibition of this pathway causes permanent growth arrest/cell death. Reactive oxygen species, a byproduct of oxidative processes, can induce an irreversible growth arrest similar to SERM antiestrogens. SERMs are capable of producing ROS through their metabolic activation. These findings suggest that SERMs may mediate growth arrest by a mechanism involving ROS accumulation. ${ }^{61,62}$

Third-generation aromatase inhibitors (AIs), such as anastrozole, letrozole, and exemestane that have a non-steroidal structure, also play a role in breast cancer treatment. As their name implies, AIs prevent conversion of androgen to estrogen by inhibiting 
aromatase enzyme activity in the cells. Thus AIs inhibit the mitogenic response in the breast tissue by inhibiting both estrone (E1) and estradiol (E2) production. ${ }^{63}$ While firstand second-generation AIs have been found to be quite effective, the side effects have caused the use of them to be controversial. Third-generation AIs, on the other hand, appear to have complete specificity without adrenal axis affects. AIs are used on women with ER/PR expression, but who do not have functional ovaries or who are premenopausal. The amount AIs lower estrogen expression in those who do not fit this description is not enough to have an effect on tumor growth. ${ }^{64}$

In summary, antiestrogen-mediated oxidative stress has received attention as an ERindependent mechanism. Like stilbene estrogen, tamoxifen and its metabolites produce ROS, which can lead to oxidative damages to macromolecules, such as lipids and DNA. ${ }^{65-68}$ Like tamoxifen, other SERMs can also participate as substrates in metabolic redox reactions, which in turn can also produce oxidative stress. ${ }^{61}$ This increase in redox reactions could lead to a more oxidized state of the breast cancer cell, leading to cellular adaptation to ROS signaling, and a new cellular state that allows cell cycle progression in the presence of tamoxifen and possibly other SERMs.

\section{Overview of existing paradigms of antiestrogen resistance}

A major problem with the use of antiestrogens is the prevalence of resistance, either at the outset of treatment or after continued use. De novo, or primary, resistance can occur when tumors do not express estrogen or progesterone receptors. ${ }^{69} 70,71$ As most estrogenic actions are considered to be mediated through the ER, lack of this protein 
causes an inherent resistance to endocrine therapies, ${ }^{72}$ but this does not explain the 40 $50 \%$ of people who do not respond to treatment despite steroid hormone receptor expression. ${ }^{73}$ A more recent discovery in de novo resistance is inactive alleles of cytochrome P450 2D6. This allelic inactivity keeps patients from being able to convert tamoxifen to its active metabolite, endoxifen, leading to a decreased response to tamoxifen. Patients who initially respond to antiestrogen treatment often become resistant to the drug within 2 to 5 years. ${ }^{26}$ The decreasing sensitivity of ER-positive breast cancer cells to antiestrogens with time is caused by several factors, and different mechanisms have been proposed to explain antiestrogen resistance. Since mechanisms of AE resistance have been widely reviewed, ${ }^{72}$ we have briefly summarized them here.

Cross talk between ER and growth factor signaling has emerged as one of the important mechanisms in endocrine resistance. Since ER $\alpha$ expression plays a key role in predicting the response a patient will have to hormonal therapy such as antiestrogens, ${ }^{69}$ it is considered that a loss of ER $\alpha$ expression would be responsible for an acquired resistance to antiestrogens. Most data is related to tamoxifen treatment, ${ }^{69}$ and it shows that only approximately $17-28 \%$ of patients with acquired resistance to tamoxifen have a loss of ER $\alpha$ expression. ${ }^{26}$ There is also the possibility of ER mutations causing loss of functionality, or that the ER continues to drive all estrogenic actions except growth. ${ }^{72}$ But again, fewer than $1 \%$ of ER positive tumors have been found to have ER $\alpha$ mutations. ${ }^{74}$ Another possibility lies in a truncated version of ER $\alpha, E R \alpha 36$. When ER $\alpha 36$ is in the presence of the full ER $\alpha$, there is decreased responsiveness. Posttranslational modification of $\mathrm{ER} \alpha$ regulates its function as well as its interactions with other proteins 
such as ER $\alpha$ co-regulators. Co-regulators include AP-1 and NF- $\mathrm{BB}$, and phosphorylation and overexpression of these co-regulators can cause an increase in ER $\alpha$-mediated transcription, which has been associated with endocrine resistance. ${ }^{74}$

Mechanisms different from the ER have been proposed in antiestrogen resistance, with ErbB2 overexpression being the best characterized. Breast cancers that are resistant to tamoxifen have shown an increase in the expression of receptor tyrosine kinase (RTK) members, such as epidermal growth factor receptor pathway members like ErbB1 and ErbB2. ${ }^{75}$ When ErbB1 and ErbB2 (also known as HER-2) are overexpressed, they can reduce the levels of the cyclin-dependent kinase inhibitor p27 and inhibit its function, and thus keep tamoxifen from activating this molecule to keep the cell in G1 arrest. ${ }^{76}$ Not only does Her2 overexpression contribute to resistance on its own, but Her2 dimerization with other members of the ErbB receptor family can also lead to antiestrogen resistance. ${ }^{77}$ Overexpression of other tyrosine kinases, such as Src kinase family members, is seen in breast cancer, and has been implicated in resistance through its substrate BCAR $1 .{ }^{74}$

Overexpression of cell cycle proteins such as Myc and cyclin D1 is associated with tamoxifen resistance, as is a decrease in expression of the NF- $\kappa \mathrm{B}-$ binding interferonresponsive putative tumor suppressor, IRF $1{ }^{74}$ Response to tamoxifen is also correlated with the expression of the MAPK inhibitor, MAPK phosphatase 3 (MKP3), with resistant cells expressing increased levels of MKP3. ${ }^{78}$ 
Current hypotheses in tamoxifen resistance do not include the effect of a chronic exposure to ROS that is created by tamoxifen. Certainly tamoxifen is not known to work through a ROS-mediated pathway, but it does increase ROS. As such, the longterm exposure of breast cancer cells to tamoxifen- (and estrogen-) mediated ROS production may play a role in tamoxifen resistance. In the following section we explore this novel hypothesis.

\section{Redox signaling and antiestrogen resistance}

Before we discuss the role of redox signaling in antiestrogen resistance, we would like to briefly introduce the basic conditions that produce changes in the redox state of cells, generation of ROS and concepts of redox signaling.

Redox state of cells: Historically, the term redox state has been used to describe the ratio of the interconvertible oxidized and reduced forms of a specific redox couple. The three major redox couples in cells are NADP+/NADPH, GSSG/2GSH, and TrxSS/Trx(SH)2. These redox couples are not isolated systems; rather they are thermodynamically connected to each other in the maintenance of redox equilibrium of cells. For example, both the Trx and GSH systems use NADPH as a source of reducing equivalents, ${ }^{79}$ and a decrease in thioredoxin reductase affects glutathione reductase activity in glucocorticoidresistant Alopecia areata ${ }^{80}$ Redox couples in cells are responsive to electron flow, that is, changes in the reducing/oxidizing environment. When the products of the reducing capacity and the reduction potential of a linked set of redox couples in cells or tissue are added, it is considered the redox environment. ${ }^{79}$ 
As is true with the control of $\mathrm{pH}$ within the body, the redox environment is well governed through what is known as redox regulation. In this process, redox homeostasis is disturbed by increases in the formation of ROS or decreases in the actions of antioxidant systems. This imbalance towards oxidation allows for redox signaling to occur. When pathological conditions are present, however, these oxidizing conditions can accumulate and have the potential to cause changes in cell signaling, which is commonly seen in disease states. $^{81}$

When a cell loses its capacity to reduce redox couples, ${ }^{82}$ there is a higher production of ROS or reactive nitrogen species, which result in a production or reaction from the antioxidants and reducers within the cells. This is explained below.

Reactive oxygen species (ROS) is a term extended to a range of molecules, including free radicals (which contain one or more unpaired electrons) and include superoxide $\left(\mathrm{O}_{2}{ }^{-}\right)$, hydrogen peroxide $\left(\mathrm{H}_{2} \mathrm{O}_{2}\right)$, hydroxyl radical $(\mathrm{OH})$, and peroxynitrite $\left(\mathrm{ONOO}^{-}\right) .{ }^{83}$ Several enzymatic systems and organelles create ROS, such as NADPH oxidase complex, cytochrome 450, nitric oxide synthases, xanthine oxidase, peroxisomes, endoplasmic reticulum and mitochondria. ${ }^{84,85}$ The mitochondria, however, are the largest source of ROS in epithelial cells, ${ }^{29}$ and most ROS in endothelial cells are developed in the mitochondria through the electron transport chain. ${ }^{83}$ ROS are created when oxygen $\left(\mathrm{O}_{2}\right)$ is put through an oxidoreduction conversion in the mitochondrial electron transport chain. There are four complexes relating to this chain through which electrons travel; the electrons are accepted by complex I (NADH-ubiquinone oxidoreductase) from NADH. 
The electrons then move to complex II, succinate dehydrogenase. At this complex, the succinate is oxidized to fumarate, and the electrons continue to complex III, ubiquinolcytochrome $c$ oxidoreductase, and then to complex IV, cytochrome c oxidase. When they finish the travel through all four complexes, they reduce molecular oxygen to water. Throughout this process, however, a small amount (1-4\%) of the oxygen is not fully reduced and results in $\mathrm{O}_{2}{ }^{--}$. This release of $\mathrm{O}_{2}{ }^{--}$from the transport process occurs mainly at complexes I and III, with complex I-generated $\mathrm{O}_{2}{ }^{-}$being released only into the mitochondrial matrix, and complex III- $\mathrm{O}_{2}{ }^{-}$being released into both sides of the inner membrane of the mitochondria. ${ }^{86}$

The enzymes that reduce proteins or destroy ROS are as important players as the ROS themselves. ${ }^{87}$ When there is a production of ROS within the cells, there is the reaction of the production of antioxidants. This is called redox (reduction and oxidation) regulation. ${ }^{81}$ There are several antioxidant systems, both enzymatic and non-enzymatic, in place to counteract redox imbalance. Enzymatic systems include superoxide dismutase (SOD), catalase, peroxiredoxins and glutathione peroxidase, while non-enzymatic systems include glutathione, thioredoxin, and vitamins $\mathrm{C}$ and $\mathrm{E}^{88}$ Superoxide does not easily diffuse across the membrane of the mitochondria. While mechanisms do exist for this to occur (voltage dependent anion channels), SOD can reduce the superoxide to hydrogen peroxide $\left(\mathrm{H}_{2} \mathrm{O}_{2}\right)$, which does easily cross the membrane. ${ }^{81,86,89}$ SOD has three isoforms; copper-zinc (CuZnSOD) in the cytoplasm, nucleus, and mitochondrial intermembrane space, a second form of CuZnSOD in the extracellular space, and magnesium SOD (MnSOD) in the mitochondrial mix. While they serve similar functions, 
MnSOD appears to be highly important physiologically, for it's genetic removal is embryonically lethal. ${ }^{86}$ Once SOD has changed the $\mathrm{O}_{2}{ }^{-}$to $\mathrm{H}_{2} \mathrm{O}_{2}$, catalase and glutathione peroxidase within the cell can then reduce the $\mathrm{H}_{2} \mathrm{O}_{2}$ to water, or, in the presence of transition metals, to the hydroxyl radical $\left(\mathrm{OH}^{-}\right) .{ }^{86} 81,89$ Figure 2-LR summarizes the major mammalian ROS and antioxidant systems. For a more in depth discussion on these processes see ${ }^{88,90,91}$.

Reactive oxygen species as signaling molecules: ROS are known signaling molecules, meaning there is a stimulus and a response to the ROS from a protein of either activation or inhibition. This response is amplified through the activation or inhibition of effector molecules further downstream in the pathway, and there is reversibility so that the pathway can be responsive to more than just the one stimulus. While not all ROS modifications are regulatory in function, glutathione and thioredoxin, as well as enzymes that are associated with each, have been found to reduce the thiol oxidation that occurs through ROS. It has been compared to the regulatory effect of phosphorylation and dephosphorylation of proteins. $^{92}$

ROS can instigate both apoptosis and cell proliferation, depending on the dose. ${ }^{25,93}$ For example, in HT-29 colon cancer cells, toxic levels of $\mathrm{H}_{2} \mathrm{O}_{2}(1,000 \mathrm{uM})$ lead to apoptosis, while lower doses, $(10 \mathrm{uM})$ induce cell proliferation. ${ }^{94}$ And when MCF-7 clones overexpress IL-1 $\beta$, which leads to a high IL-1 $\beta$ output and thus a high ROS generation, cells undergo apoptosis. When, however, a moderate level of IL-1 $\beta$ is secreted in these clones, it leads to clonal expansion. ${ }^{9}$ Mitochondrial ROS have been implicated in cell 
signaling in several pathways, including integrins, platelet-derived growth factor, epidermal growth factor, and nerve growth factor. ${ }^{95}$ When the cells undergo stress such as chronic inflammation (often from infections) and chronic chemical insults (such as tobacco smoke), there can be a transformation of the cell due to the ROS created by these irritants. This transformation often causes a lack of cell cycle regulation at cell cycle checkpoints. As such, the cells will overexpress growth factors that are oncogenic, leading to cell proliferation. ${ }^{96}$ In a number of cell lines, hormones, cytokines, neurotransmitters and growth factors can instigate cell signaling ${ }^{97}$ through inducing a low-concentration oxidative burst that may lead to signal initiation. ${ }^{98}$ For example, in endothelial cells, TNF- $\alpha$, IL-1, bradykinin and thrombin can generate superoxide, and TGF- $\beta 1$ and bradykinin can generate $\mathrm{H}_{2} \mathrm{O}_{2}$. These ROS are created to mediate mitogenic signaling, to regulate gene expression, to induce mRNA, and to move the cell cycle progression from $\mathrm{G} 0 / \mathrm{G} 1$ to $\mathrm{S}$ phase. ${ }^{95} \mathrm{ROS}$ produced by the estrogen-induced cytokine Interleukin- $1 \beta$ can lead to cell proliferation through AP-1 and NF- $\mathrm{KB}$ binding sites and through the MAPK/AP-1 and ROS/NF-kB pathways. ${ }^{99}$ Estradiol can lead to an overexpression of IL-1 $\beta$ in MCF-7 cells, which then leads to cell proliferation. When these cells are exposed to antioxidants and mitochondrial blockers, both a decrease in cyclin D1 expression and a suppression of cell growth can be seen. ${ }^{100}$ In a study of MCF7 cells treated with $17 \beta$-estradiol and insulin-like growth factor, it was shown that the combination of these elements increased peroxide production. ${ }^{101}$ The role of mitochondrial ROS production in regards to signal transduction can be seen in HeLa cells that lack mitochondrial DNA, which show a reduced ROS level, as well as a decrease of 
cell cycle progression at all phases, and a decrease in certain cell-cycle regulators such as p21 and p27. This decrease is attributed to the lack of ROS production. ${ }^{102}$

The apoptotic effect of cytotoxic levels of ROS is one way in which mitochondria play a role in chemotherapy-induced apoptosis. ${ }^{96}$ Camptothecin, mechlorethamine, and doxorubicin all induce apoptosis in breast cancer cells. ${ }^{103}$ Other ROS-utilizing chemotherapies include epirubicin, topotecan, and cisplatin. ${ }^{104}$ Dicumarol, an anticoagulant that creates oxidative stress and induces cytotoxicity in human pancreatic cancer cells, is thought to work through the electron transport chain in the mitochondria to create superoxide and hydrogen peroxide. This action of increasing cytotoxicity in these cells is decreased in pancreatic cancer cells that do not express functional mitochondria. ${ }^{105}$

Redox signaling: Redox changes in the cell are critical for initiating various signaling pathways [see above]. Three of the major cell signaling pathways involve: (i) protein phosphorylation, (ii) protein acetylation or (iii) protein thiol status change that occurs because of alterations in cellular redox environment. Change in the thiol status of the cell can be triggered by both oxidants and reductants. We now know that signal transduction, DNA and RNA synthesis, protein synthesis, enzyme activation, cell cycle regulation, ligand binding, DNA binding, and nuclear translocation are altered by changes in the cellular redox environment. Most eukaryotic transcription factors such as AP-1, NF-kB, and Sp- $1^{106}$ and glucocorticoid ${ }^{107}$ and estrogen receptors ${ }^{108}$ are affected by the redox environment. They must be in their reduced form to be active, and their translocation to 
the nucleus is often redox-dependent. ${ }^{79,106}$ We discuss below the molecular mechanisms of redox signaling in more detail.

As a known signaling molecule and second messenger, ROS has the potential to make dramatic changes in cell cycle progression. As mentioned earlier, high levels of ROS can lead to apoptosis while low levels can lead to cell cycle progression. Yet another action of ROS includes cell adaptation to chronic exposure of low to moderate levels. At moderate levels, ROS can use reversible protein oxidation to regulate signaling pathways. The common foci of this are protein kinases and transcription factors. This regulation can lead to an adaptation of the cell to changes in its environment. ${ }^{109}$ For example, when renal cells are exposed to oxalate, the initial reaction is cell death, but after 48-72 hours they can adapt to the exposure and begin to grow. ${ }^{110}$ In muscles, it has been suggested that exercise-induced ROS, as well as muscle-derived cytokines, play a role in muscle adaptation to exercise. ${ }^{111}$ The treatment of cisplatin on HepG cells increases ROS tremendously, with levels returning to normal after 120 hours. At the same time, the mitochondria membrane potential changes, but then also returns to normal by 120 hours despite continued exposure. It is suggested that this occurs due to the cells adapting to the experience of cisplatin exposure. ${ }^{112}$

This adaptation to ROS could play a role in breast cancer resistance to tamoxifen. As tamoxifen is known to increase levels of ROS and this increase is not at a high level that leads to apoptosis, there appears to be a low to medium exposure of cells to tamoxifenrelated ROS. The ROS produced may alter cell signaling, and the cell may begin to adapt 
to this new signaling function and learn to grow in the presence of tamoxifen. Figure 3LR summarizes these ROS actions in the cell. In the next sections we discuss possible protein adaptations that can occur from this constant exposure to ROS via tamoxifen.

\section{Redox regulation of protein tyrosine phosphatases/kinases: Along with the} alteration of transcription factors and certain receptors, the modification of protein phosphatases and kinases by ROS must also be considered. ${ }^{113}$ Cell proliferation, differentiation, activation, homeostasis and apoptosis are all furthered by tyrosine phosphorylation, as well as threonine and serine phosphorylation (though these play a lesser role). This phosphorylation is regulated by protein tyrosine kinases and protein tyrosine phosphatases. ${ }^{114}$

Protein-tyrosine phosphatases (PTPs) are a part of the family of cysteine-based phosphatases. ROS plays its role most especially in PTPs, which have a signature motif made up of a cysteine, five X (any) amino acids, and Arginine (Cys-Xaa(5)-Arg). This motif allows for redox regulation of proteins when the cysteine residues react with ROS. ${ }^{115}$ The PTP catalytic cysteine, which remains as an etiolate anion (Cys-S-) under reducing conditions, only requires mild oxidative conditions to be oxidized to sulfenic acid (Cys-SOH). Once in this oxidized form, there is a continued vulnerability to ROS, and it can become terminally oxidized as sulfinic $\left(\mathrm{Cys}-\mathrm{SO}_{2}\right)$ and sulfonic $\left(\mathrm{Cys}-\mathrm{SO}_{3}\right)$ acids. This can be averted by interactions with a protein structure such as a thiol. This interaction can protect the cell through creating an inter- or intra-molecular disulfide

bond that does not allow any other reactions to occur at the catalytic cysteine. ${ }^{87,115-117}$ 
The counter proteins to PTPs are protein tyrosine kinases (PTKs). An important role of PTPs and PTKs is their ability to turn on and off the action of the protein on which they are exerting their influence. ${ }^{117}$ The PTP's common active motif exists as a thiolate, ${ }^{118}$ which allows PTPs to perform their dephosphorylation activity on phosphoproteins or phospholipids. Oxidation of PTPs can be reversed by thiol compounds ${ }^{118}$ once the catalytic cysteine forms a disulfide bond with an N-terminal cysteine. This disulfide bond can originate from same site cysteines, as is the case with low molecular weight PTPs, ${ }^{119}$ from "distant" cysteines such as with PTEN and cdc25, ${ }^{120}$ or from a bond between the PTP and a thiol, such as with PTP1B. ${ }^{121}$ The important step of the disulfide bond blocks the oxidation of the thiolate to $\mathrm{Cys}-\mathrm{SOH}$ by connection to another thiolate. Oxidation and phosphorylation have the potential of influencing each other in the signaling of PTPs and PTKs. It is suggested that one may actually be a preparatory modification for the other. For example, PTP phosphorylation can increase the catalytic activity of the protein. This, in turn, opens the protein to oxidation. ${ }^{118}$

The reversibility of PTP oxidation is critical to cell signaling response. It has been suggested that at physiologic levels, one of the roles of ROS is to oxidize PTPs to encourage redox signaling. ${ }^{122}$ Structural changes to PTPs, as well as serine/threonine and phospholipid phosphatases, are induced by ROS, and the altered protein conformation leads to signaling cascade upregulation. Included in these cascades are growth factor kinase-dependent, src/Abl kinase-dependent, MAPK-dependent, and PI3 kinasedependent pathways, leading to activation of AP-1, NF- $\mathrm{B}, \mathrm{HIF}-1$, and other redoxregulated transcription factors. ${ }^{88}$ 
Redox regulation of transcription factors: Certain transcription factors such as AP-1 and NF- $\mathrm{kB}$ are known to be redox regulated. ${ }^{106} \mathrm{AP}-1$ is a heterodimeric transcription factor that has been found to regulate cell proliferation, death, survival, and differentiation, ${ }^{123}$ depending on several factors. These factors include the balance of target genes that are either pro- or anti-apoptotic, the type of stimulus that induced the AP-1, and the persistence of that stimulus. ${ }^{88}$ The components of AP-1, c-Jun and c-Fos, can be induced by reactive radicals, and can positively regulate proliferation. ${ }^{88}$

Because of their regulatory actions on transcription factors, most especially MAPkinase/AP-1 and NF-kB, ROS are able to alter cell proliferation, differentiation, and apoptosis. ${ }^{81,124,125}$ Since certain cell cycle genes contain response elements for these transcription factors, ROS can activate these genes and lead to cell proliferation. ${ }^{126}$ ROS actions regarding these transcription factors can be different depending on the cell line, however. For example, $\mathrm{H}_{2} \mathrm{O}_{2}$ is known to activate $\mathrm{NF}-\mathrm{kB},{ }^{127}$ and in cardiovascular vessels, ROS activates AP-1 and NF- $\mathrm{kB} .{ }^{128}$ In normal melanocytes, oxidative stress can be "suppressed" without the recruitment of NF- $\mathrm{KB}$ and AP-1. In melanoma cells, on the other hand, redox changes easily recruit NF- $\mathrm{KB}$ and AP-1. In these cells, NF- $\mathrm{\kappa B}$ is correlated to $\mathrm{H}_{2} \mathrm{O}_{2}$ and not superoxide, and AP-1 to superoxide anion and not $\mathrm{H}_{2} \mathrm{O}_{2}{ }^{129}$ AP-1 can, however, be induced by $\mathrm{H}_{2} \mathrm{O}_{2}$ in other cells, mainly through the JNK and p38 MAPK signaling pathways. This can be done through either ASK1 (apoptosis signalregulating kinase 1 , which is released on thioredoxin oxidation as discussed below) or through the inhibition of MAPK phosphatases (which in turn leads to increased kinase activity). ${ }^{88}$ In tamoxifen resistant breast cancer, oxidative stress is implicated in an 
increased AP-1 DNA binding with c-JUN NH2 terminal kinase activity in tamoxifen resistant breast cancer. ${ }^{68,130,131}$

Reactive oxygen species are significant outcomes of estrogen and tamoxifen actions in cells. Tamoxifen resistance has an association with oxidative stress in breast cancer cells, and this leads to an increase in c-Jun and phosphorylated JNK levels, as well as an increase in AP-1 activity. A significant decrease in glutathione levels has been shown in tamoxifen resistant MCF-7 xenograft tumors, though there is an increase in SOD and glutathione S-transferase levels. ${ }^{68}$ And when vitamin $\mathrm{E}$ is added to tamoxifen-treated breast cancer cells, cell proliferation and ERK phosphorylation, which are normally decreased with tamoxifen treatment, are restored. ${ }^{132}$ It is with this in mind that we now discuss the thioredoxin system.

Thioredoxin system and redox regulation: For this review, our focus is not on the mechanisms of antiestrogen treatment, but rather the resistance that occurs with treatment. To explore how redox regulation may play a role in antiestrogen resistance, we will discuss the possible involvement of thioredoxin and the thioredoxin family. In the following section we discuss the role of ROS in Trx oxidation, and then a potential role in tamoxifen resistance.

Thioredoxin (Trx) is a $12 \mathrm{KD}$ disulphide reducing enzyme that is excreted by a variety of cells. ${ }^{133,134}$ The importance of thioredoxin can be seen with its role within the DNAbinding sites of several transcription factors, where it reduces cysteine moieties and thus 
plays a role in gene expression. ${ }^{135}$ There are five cysteines in $\operatorname{Trx}(32,35,62,69$, and 73), ${ }^{136}$ two of which (32 and 35) are in the highly conserved domain of redox regulation ${ }^{137}$ with the sequence Trp-Cys-Gly-Pro-Cys. ${ }^{106}$ There are three forms of Trx; Trx1 (herein called Trx) that is cytosolic, the mitochondrial form (Trx2), and a third (SpTrx) that is found in spermatazoa. ${ }^{138}$ The cytosolic mammalian Trx, lack of which is embryonically lethal, has numerous functions in the defense against oxidative stress, control of growth and apoptosis. It also has co-cytokine and chemokine activities. ${ }^{139}$ Thioredoxin is secreted in times of oxidative stress and inflammation in both normal and neoplastic cells. ${ }^{139}$ It has been suggested that $\operatorname{Tr} \times 2$ may be protective to cells during such exogenous insults as radiation and certain anticancer drugs. ${ }^{140}$ It has also been suggested that $\operatorname{Tr} x 2$ and peroxiredoxins (Trx peroxidases) regulate the release of cytochrome $\mathrm{c}$.

As discussed above, an important aspect of the redox state is the role of cysteine residues and thiol chemistry. ${ }^{92}$ ROS is particularly drawn to cysteine and methionine residues, ${ }^{88}$ and when these residues are oxidized, they are reduced by thioredoxin and glutathione/glutaredoxin-dependent reactions. ${ }^{139}$ Thioredoxin and glutathione are the major factors in maintaining reduced proteins, ${ }^{81,139}$ and these reducing agents are found, in normal cells, in their reduced form. When they perform their reduction actions on oxidized proteins, they themselves are oxidized. They are then returned to their reduced forms through the use of thioredoxin reductase and glutathione reductase, respectively. Cysteine residues have been found to be specific targets for ROS when in the thiolate (-S) form, making them susceptible to ROS modification. ROS is drawn to reactive cysteine residues in target proteins. When the cysteine residue is in the thiol form (-SH) it is not 
highly reactive and requires some catalyst to encourage reaction with a hydroperoxide. When the cysteine residue is in the thiolate form, however, it can react easily with ROS. ${ }^{141}$ Thiol chemistry has been well reviewed, and thus is only discussed in the context of this paper. For an extensive review, see Forman et al. ${ }^{141}$

Trx is ubiquitous and has a variety of functions, including gene regulation (such as with NF- $\mathrm{kB}$ and $\mathrm{p} 53$ ), regenerating antioxidant enzymes, and catalyzing antioxidant reactions. Trx also can indirectly affect MAPKs and phosphoprotein phosphatases. When in the cytoplasm, Trx functions more as a reducing agent and an antioxidant, whereas in the nucleus it is a transcription factor regulator. ${ }^{142}$ In breast carcinomas, immunoreactivity of Trx in the nucleus is related to $\mathrm{p} 53$ positivity and to proliferation, as well as to an inverse association with estrogen and progesterone receptor status. ${ }^{143}$

Trx is induced by stressors, including mitogens and $\mathrm{H}_{2} \mathrm{O}_{2}$. In stromal cells, both $\operatorname{Trx}$ mRNA and protein are increased with $17 \beta$-estradiol treatment. This effect is suppressed when tamoxifen treatment is given. It is also suggested that Trx might act with EGF, another secretion of stromal cells upon E2 treatment, as a co-mitogen. ${ }^{144}$ Intracellular levels of Trx increase when human skin fibroblasts have been UVA-irradiated, as have, in a time-dependent manner, Trx mRNA. This irradiation may lead to the translocation of Trx from the cytosol to the nucleus, and to an increase in thioredoxin reductase. ${ }^{145}$ In HIV patients, it has been seen that the loss of CD4+ T-cells by apoptosis is preceded by depletion of, among other redox molecules, glutathione and thioredoxin. An increase in ROS and a change in the $\Delta \psi m$ are also seen before the T-cell loss. ${ }^{146}$ 
Thioredoxin has been linked to cancer in a variety of ways, and it is associated with several effects, such as decreased survival and aggressive tumor growth. Cancer cells can secrete Trx, and there have been reports of high levels of Trx in certain cancers, namely cervical, hepatoma, gastric, lung, and colorectal. In human leukemia cells and solid tumor lines, growth can be stimulated by $\operatorname{Trx} .^{81}$

The redox state of Trx is important to its function, and as such, the role of Trx reductase (TrxR) is key. In both $\operatorname{Trx}$ and $\operatorname{TrxR}$ there are cysteine molecules that are key to redox regulation. ${ }^{133,134}$ TrxRs are NADPH-dependent, and they catalyze disulfide reduction at thioredoxin active sites. In turn, reduced thioredoxins catalyze the movement of active site dithiols to a disulfide state. This process has given the thioredoxin family a crucial role in cell-growth and apoptosis, as it is through this process they can regulate enzymes such as ribonucleotide reductase, peroxiredoxins and transcription factors. ${ }^{147}$

When exposed to oxidants or nitrosothiols, Trx quickly translocates to the nucleus, ${ }^{148}$ and acts in the control of transcription factors. ${ }^{149}$ A growing number of transcription factors, including NF-kB or Ref-1-dependent AP-1, are showing a need for thioredoxin reduction for DNA binding. ${ }^{139,150}{ }^{123}$ When Trx is overexpressed, NF- $\kappa \mathrm{B}$ is downregulated and AP-

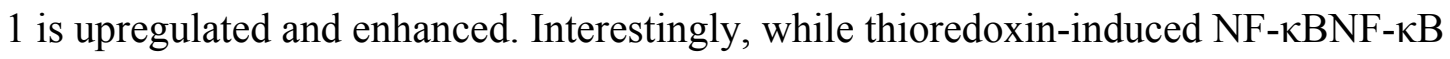
inhibition is found in the cytoplasm, Trx can increase NF-kB binding to nuclear DNA.

The TXNRD1 gene encodes for thioredoxin reductase 1, and transcription involves alternate splicing, and thus leads to several isoforms. ${ }^{151}$ The three TrxR enzymes that 
have been identified in mammals are TrxR1, TrxR2, and TGR. TGR is expressed mostly in the testis, and TrxR2 is a mitochondrial form. TrxR1 (herein called TrxR) is the cytosolic enzyme, and, like Trx, is widely expressed. ${ }^{149,152} \operatorname{TrxR}$ belongs to the homodimeric pyridine nucleotide disulfide oxidoreductase class. ${ }^{152}$ It is a homodimeric selenocysteine-containing protein, and thus is dependent on selenium for its synthesis. ${ }^{149}$ ${ }^{82}$ Selenium (selenite, $1 \mathrm{uM}$ ) increases the mRNA levels of TrxR by two- to five-fold. ${ }^{149}$ TrxR has the capability of metabolizing certain selenium compounds, and it is thought that through this process, TrxR can reduce the active site of plasma glutathione peroxidase, another selenoprotein. ${ }^{153} \operatorname{TrxR}$ has been found to be elevated in several cancerous cell lines ${ }^{133,149}$ including pancreatic, cervical, hepatocellular, and certain lung cancers, ${ }^{21}$ and repressed in cells that overexpress the p53 protein. Several studies have looked at the rise of TrxR in cancer cells. ${ }^{149}$

Thioredoxin and thioredoxin reductase work together with NADPH to form a system that, through redox regulation, control processes such as DNA synthesis, transcriptional regulation, and cell growth. They also confer resistance to cytotoxic agents that produce oxidative stress and lead to apoptosis. While thioredoxin is a reducer of proteins that have oxidized cysteine residues, it also is susceptible to oxidation as it contains one cysteine in the thiolate form. The reaction of thioredoxin is described as follows:

$$
\mathrm{RS}^{-}+\mathrm{H}_{2} \mathrm{O}_{2} \rightarrow \mathrm{RSO}^{-}+\mathrm{H}_{2} \mathrm{O}+\mathrm{H}^{+}
$$

As is true with other cysteine-based proteins, thioredoxin can create a disulfide bond, either intramolecularly or with peroxiredoxin. This form of the protein then is not open 
for interaction with other thiols or thiolates, and requires thioredoxin reductase to reduce its disulfide status. To do this, thioredoxin reductase works with NADPH as follows:

Trx reductase

$\operatorname{Tr}\left(\mathrm{S}_{2}\right)+\mathrm{NADPH} \quad \rightarrow \quad \operatorname{Trx}(\mathrm{SH})\left(\mathrm{S}^{-}\right)+\mathrm{NADP}^{+}$

In Trx and TrxR, the redox signal can change the cysteine sulfur molecule from $-\mathrm{CH}_{2}-$ SH to $-\mathrm{CH}_{2}-\mathrm{S}^{-}$. This "sulfhydryl switch" allows for changes in the enzymes' activities. Once oxidative stress has occurred, the TrxR charges the sulfur atoms on the Trx, activating the Trx. And once activated, Trx can move from the cytoplasm to the nucleus where it activates Ref-1, which further activates transcription factors that can protect the cell from oxidative stress. ${ }^{133}$

Thioredoxin reductase and glutathione reductase have similar homologies, and also have some overlap of function. Similarly, thioredoxin and glutaredoxin also have an overlap of function. Thioredoxins, however, are able to catalyze disulfide reduction much faster than GSH. ${ }^{139}$

Trx family and ROS: There are several published examples of Trx's susceptibility to ROS. There is a variety of compounds that have been found to oxidize Trx, such as $\mathrm{H}_{2} \mathrm{O}_{2}$, superoxide, ${ }^{154}$ paraquat, rotenone, ${ }^{155}$ and 2-[(1-methylpropyl)dithio]-1H-imidazole (PX12). ${ }^{156}$ PX-12 (also called IV-2) not only oxidizes TrxR, but also irreversibly inhibits Trx protein function through cysteine residue oxidation. ${ }^{156}$ In human lens epithelial HLE B3 cells, when $\mathrm{H}_{2} \mathrm{O}_{2}$ treatment was given, Trx expression increased. ${ }^{157}$ In keratinocytes, lymphoid, and HeLa cells, $\mathrm{H}_{2} \mathrm{O}_{2}$ exposure leads to an increase in Trx mRNA levels. ${ }^{158}$ 
When endothelial cells are exposed to low doses of ROS, (10 and $50 \mu \mathrm{M} \mathrm{H}_{2} \mathrm{O}_{2}$ and shortterm exposure to shear stress), significant increases in Trx mRNA and protein levels are seen. It follows, then, that there would also be a reduction in apoptosis induction, and when Trx expression is reduced and low doses of ROS administered, apoptosis is induced. Thus a portion of the anti-apoptotic nature of low-dose ROS in endothelial cells could be due to the increase in Trx expression. ${ }^{159}$

It is thought that lung injury that occurs with bleomycin anticancer therapy is due in part to ROS. Trx, but not $\mathrm{Cu} / \mathrm{Zn}-\mathrm{SOD}, \mathrm{mnSOD}$, catalase, or glutathione peroxidase is strongly induced in the lungs of mice treated with bleomycin, suggesting that Trx may modify the reduction and oxidation state in bleomycin resistance, and perhaps may be protective against bleomycin-induced lung injury. ${ }^{160}$

Trx scavenges ROS that has been created by diesel exhaust particles (DEP). While acute lung disease and an increase in inflammatory cells were seen in control mice, human Trx transgenic mice appeared to be protected from this injury. L929 cells that had been hTrx1 transfected and A549 cells pretreated with recombinant human Trx were utilized. A downregulation of the phosphorylation of Akt was shown, which led to apoptosis. This downregulation and subsequent cell death was prevented by treatment with Trx. It was also seen that when Akt was inhibited in the cells, the protective effect of Trx was canceled. These results show that Trx may play a protective role against DEP and subsequent lung damage via Akt regulation. ${ }^{161}$ 
It is thought that oxidative stress that is present in hyperhomocysteinemia is due to impaired Trx and subsequent increased ROS. ${ }^{162}$ Low-dose exposure to 5-aminolaevulinic acid-based photodynamic therapy (ALA-PDT, a treatment for superficial skin cancer) increases Trx expression and leads to cell growth, while high-dose exposure showed apoptosis with minimal Trx expression. ${ }^{163}$

Trx acts as a cofactor for peroxiredoxins in their role as $\mathrm{H}_{2} \mathrm{O}_{2}$ scavengers. Trx and peroxiredoxin I are elevated in human lung tissues by hypoxia. ${ }^{140} \mathrm{MCF}-7$ cells that have been transfected with Trx also have an increase in the expression of Trx peroxidase- 1 , an $\mathrm{H}_{2} \mathrm{O}_{2}$ scavenger. This expression protects against $\mathrm{H}_{2} \mathrm{O}_{2}$-induced apoptosis, but not against apoptosis induced by anti-cancer drugs such as etoposide and doxorubicin. ${ }^{164}$ In a study of 89 non-small cell lung carcinomas, Trx and TrxR were found in all but 3 and 8 cases, respectively, and were both cytoplasmic and nuclear. When the expression of these proteins was nuclear, there was an inverse association with apoptosis. When the grade of the carcinoma was high, there was a decrease in Trx and TrxR expression. ${ }^{165}$ Thioredoxin peroxidase II (also known mitochondrial peroxiredoxin 3) ${ }^{166}$ can decrease $\mathrm{H}_{2} \mathrm{O}_{2}$ when overexpressed, and through this mechanism can inhibit apoptosis. ${ }^{139}$

The dietary isothiocyanates sulforaphane, erucin, and iberin have been found to induce thioredoxin reductase in MCF-7 cells. ${ }^{167}$ In HepG2 and undifferentiated Caco-2 cells, not only does sulforaphane induce TrxR, but also its substrate Trx. ${ }^{168}$ Selenium supplementation increases TrxR activity in high risk prostate cancer patients, ${ }^{169}$ and mercury toxicity can lead to the selective inhibition of TrxR. ${ }^{170}$ 
Redox regulation of proteins by Trx: Trx family under- or over-expression has been related to a number of diseases and their effects, from airway remodeling, ${ }^{171} \mathrm{H}$. felisinduced gastritis, ${ }^{172}$ Sjögren's syndrome, ${ }^{173}$ and angina ${ }^{174}$ to alopecia areata-based glucocorticoid resistance,${ }^{80}$ decreased cystic fibrosis sputum, ${ }^{175,}, 176$ and ischemiareperfusion injury prevention. ${ }^{177,178} \operatorname{Trx}$ is also both a biomarker and a therapeutic agent for cardiac disorders. ${ }^{179}$ It has been suggested that an increase in Trx in lung transplant patients can be a biomarker for organ rejection, as a significant increase in Trx was seen in bronchoalveolar lavage fluid of graft-rejecting patients in an 18-patient study. ${ }^{180}$ Metastatic colorectal cancer liver resection patients whose metastases were Trx positive presented with shorter survival than those whose tumors were Trx negative. ${ }^{181} \operatorname{Trx}$ inhibits the activity of PPAR $\alpha$, a transcription factor in the nuclear receptor family which is involved with lipid catabolism, and whose genes are targets of lipid lowering fibrate drugs. ${ }^{182}$

The majority of studies performed on the thioredoxin family are on its role as an apoptosis inhibitor. This inhibition has been seen by Trx2 overexpression in SH-SY5Y human neuroblastoma, ${ }^{183}$ lung and other cells by overexpression of Trx. ${ }^{184} 185$ In mice, TrxR overexpression inhibits apoptotic signaling and gastric ulcer formation that occurs with the treatment of the non-steroidal anti-inflammatory drug indomethacin. ${ }^{186}$ For Trx to suppress apoptosis of cisplatin-treated breast cancer cells, it must be nuclear. In MCF7 cells, when total Trx was increased with no increase in nuclear Trx, there was no change in cisplatin-mediated apoptosis. There was, however, a decrease in cisplatininduced apoptosis when nuclear Trx was increased with no change in total Trx. ${ }^{187}$ 
This propensity for inhibition has made TrxR a target of certain drugs. TrxR has been inhibited by auranofin to induce apoptosis in cisplatin-resistant $\mathrm{C} 13^{*}$ ovarian cancer cells, ${ }^{188}$ and by 1,2-[bis(1,2-benzisoselenazolone-3(2H)-ketone)] ethane and cyclophosphamide to induce apoptosis in several human cancer cell lines. ${ }^{189}{ }^{190}$ Green tea extracts inhibit TrxR in HeLa cells, which also show a concentration-dependent decrease in cell viability. ${ }^{191}$ GRIM-12 has been identified as being identical to TrxR, and GRIM12 overexpression increases apoptosis that is interferon/tamoxifen induced. On the other hand, when GRIM-12 is underexpressed, there is a resistance to interferon/tamoxifeninduced cell death and an increase in cell growth. Thus TrxR may play an important role in tamoxifen resistance. ${ }^{192}$

Thioredoxin interactions with other proteins: Thioredoxin interacts with many different proteins and acts as both an inhibitor and a regulator. One MAP3K protein that is directly affected by Trx is apoptosis signal-regulating kinase 1 (ASK1). ${ }^{149}$ In its reduced form, thioredoxin is known to inhibit ASK1 through binding to the protein. ${ }^{193}$ However, Trx becomes disassociated with ASK1 in the presence of ROS, ${ }^{193,} 194$ 149, 195 allowing ASK1 to activate the JNK/p38 pathway. ${ }^{140} 196$

Under reduced conditions, Trx binds to the N-terminus of ASK1. However, upon oxidation it become dissociated from ASK $1 .{ }^{197}$ Competition with Txnip can also interfere with Trx/ASK1 interactions. ${ }^{198}$ The importance of the Trx relationship with ASK1 can be seen with $\mathrm{H}_{2} \mathrm{O}_{2}$ exposure. This exposure leads to the oxidation of ASK1, which can be reversed by Trx. ${ }^{199}$ The loss of interaction ASK1 has with Trx upon Trx oxidation has 
been studied in several diseases. Overexpression of Trx can reduce cigarette smokestimulated apoptosis through the ASK1/JNK pathway. ${ }^{200}$ Oxidation of Trx may play a role in Alzheimer's disease as amaloid beta causes Trx oxidation and the nuclear export of the ASK1 downstream protein Daxx. ${ }^{201}$ Oxidation of Trx2, and subsequent release of ASK1, by the anti-inflammatory drug troglitazone can lead to mitochondrial permeabilization. ${ }^{202}$ The Trx/ASK1 pathway is also used in therapy modes. For example, the chemotherapeutic cisplatin has mechanisms of action that include the activation of ASK1/p38 through decreasing TrxR activity and enhancing Akt activation. ${ }^{203}$

Thioredoxin inhibiting protein (Txnip) is upregulated by ceramide, a tumor-suppressor lipid that is generated by cells under stress conditions, as well as by cancer cells exposed to genotoxic chemotherapy. This upregulation of Txnip can lead to an increase in Trx/Txnip interactions and a decrease in Trx/ASK1 interactions, freeing ASK1 to promote apoptosis. ${ }^{204}$

Trx also has regulatory abilities with cytochrome 450s, hypoxia-inducible factor-1 (HIF1), and Nrf-2. ${ }^{150}$ In non-small cell lung cancer, Trx is a HIF-1 $\alpha$ stabilizer, ${ }^{205}$ and in HT1080 cells the overexpression of Trx leads to the increase in HIF-1 $\alpha$ when under hypoxic conditions. ${ }^{206}$ Silencing of Trx decreases HIF-1 $\alpha$, as well as vascular endothelial growth factor expression. ${ }^{206}$ On the other hand, HIF-1 accumulation is decreased by Trx 2 overexpression. Trx increases and Trx 2 decreases cap-dependent translation, and HIF-1 transactivation is stimulated by Trx, but decreased by Trx 2 . From this data, it has been suggested that thioredoxins may contribute to the synthesis of HIF-1 $\alpha .{ }^{207}$ 
Nuclear factor erythroid 2-related factor $2(\mathrm{Nrf} 2)$ is a transcription factor that transcribes genes for antioxidants, xenobiotic detoxifiers, and other cytoprotective proteins. ${ }^{208} \mathrm{Nrf} 2$ is a transcription factor of thioredoxin that is activated in the cytoplasm by an oxidative signal. ${ }^{209} \mathrm{Nrf}-2$ increase in expression is correlated with an increase in Trx. ${ }^{210} \mathrm{Nrf} 2$ may assist in the regulation of the entire Trx system, as cadmium-induced Nrf2 activation and binding to antioxidant response element in the TrxR gene promoter leads to TrxR gene expression. ${ }^{211}$ For Nrf2 to bind to the DNA it must be reduced at a critical cysteine, ${ }^{209}$ and while Nrf2 translocation is regulated by glutathione, nuclear Trx regulates the antioxidant reporter element. ${ }^{212}$ An increase of Nrf2 in tamoxifen-resistant MCF-7 cells has been shown and may be due either to an enhancement in the stability in the protein with long-term exposure to tamoxifen, or to an increase in gene transcription. It has been suggested that the Nrf2/ARE-mediated increase in antioxidant proteins such as thioredoxin and peroxiredoxin 1 is involved in tamoxifen resistance. ${ }^{213}$ It does not appear to have been explored, however, if such an increase in Trx results in an increase in active Trx, as opposed to oxidized Trx, which could occur from the increase in ROS from tamoxifen treatment.

Macrophage migration inhibitory factor (MIF) is now recognized as being part of the thioredoxin superfamily, ${ }^{214}$ and Trx is able to suppress MIF production. ${ }^{215}$ It has been shown that as nuclear MIF increases, p27 levels decrease. It would seem to follow, then, if Trx were increased, MIF levels would decrease and allow p27 levels to increase. The association with Jab1 may also play a role in this as Jab1 is also known to interact with MIF. ${ }^{216}$ 
Thioredoxin inhibiting protein (Txnip) is also known as vitamin D3 up-regulated protein 1 (VDUP1) and Trx-binding protein-2 (TBP-2). ${ }^{21}$ As mentioned earlier, Txnip is an antagonist of Trx, and various stressors, including ROS, regulate its expression. ${ }^{217}$ Txnip is often decreased in tumor cells and tissues. It negatively regulates Trx, and VDUP1 (Txnip) -/- mice present with a higher susceptibility to carcinogenesis and defective immune system. ${ }^{218}$ Txnip forms a stable complex with reduced Trx that is disulfide linked. ${ }^{219}$ In the mouse uterus, estrogen treatment decreases Txnip expression and increases Trx, Trx2, and TrxR expression, as evidenced by mRNA levels. ${ }^{220}$ Txnip is found at low levels in human cancers. ${ }^{21}$ An overexpression of Txnip leads to a decrease in Trx activity, as well as slow growth and apoptosis susceptibility. ${ }^{157}$ For example, colonic mucosa from ulcerative colitis and colorectal cancer specimens have significantly decreased Txnip levels as compared to normal tissue. ${ }^{221}$

Txnip appears to be closely linked to hyperglycemia. Txnip-deficient mice that have been fed are metabolically similar to mice that have fasted. While the thioredoxin activity of the fed Txnip-deficient mice was similar to wild type, the deficient mice also presented with an increase in the NADH to NAD + ratio. ${ }^{222}$ In beta cells, glucose increases expression of Txnip and apoptosis. ${ }^{223}$ High glucose levels also increase Txnip expression in renal proximal tubule cells (HK-2). ${ }^{224}$ In breast cancer cells, hyperglycemia affects Txnip levels, with tumorigenic cells expressing a low level and metastatic cells expressing a high level. Hyperglycemia was found to increase paclitaxel cytotoxicity, and this was also associated with Txnip expression. ${ }^{225}$ In MDA-MB-231 breast cancer cells, hyperglycemia increases Txnip RNA within 6 hours of exposure. ${ }^{226}$ 
When Txnip was explored for its metabolic effects in type 2 diabetes, patients with one particular variant, TXNIP-T, had both higher diastolic blood pressure $(5.5 \mathrm{mmHg})$ and higher trigliceride concentrations (1.6 fold) ${ }^{227}$ In INS-1 insulinoma beta cells that overexpressed Txnip, 90 of 98 genes that were differentially expressed were downregulated. It is thought that Txnip is able to enhance beta-cell death and decrease insulin secretion through its modulation of genes that are involved with cell death, cell survival, and insulin secretion. $^{228}$

There are many proteins that interact with members of the Trx family. Table 1 explores many of these interacting proteins. From this table we can see the variety of ways in which thioredoxin family members may play a role in cell cycle progression, as well as how oxidation of thioredoxin can lead to a disruption in regular cell function.

\begin{tabular}{|l|}
\hline TABLE 1 Intracellular Trx family interactions \\
\hline Trx enhances AP-1 binding to DNA via Ref-1 (redox factor-1) \\
\hline Trx inhibits PPAR \\
\hline Trx inhibits Apoptosis signal-regulating kinase (ASK) 1 \\
\hline Trx1 suppresses MIF production \\
\hline Nuclear Trx regulates the antioxidant reporter element of Nrf2 \\
\hline Nrf2 transcription factor may assist in the regulation of the Trx system \\
\hline Nrf-2 increase in expression is correlated with an increase in Trx \\
\hline Overexpression of Trx2 decreases HIF-1 accumulation \\
\hline Cyanidin elevates Trx expression \\
\hline H2O2 increases Trx expression \\
\hline H2O2 increases Trx mRNA \\
\hline UVA-irradiation increases intracellular levels of Trx \\
\hline Homocysteine upregulates Trx expression \\
\hline $\begin{array}{l}\text { 5-aminolaevulinic acid-based photodynamic therapy (ALA-PDT) increases Trx } \\
\text { expression }\end{array}$ \\
\hline Sulforaphane induces Trx \\
\hline
\end{tabular}




\begin{tabular}{|l|}
\hline Cancer cells secrete Trx \\
\hline Superoxide and H2O2 oxidize Trx \\
\hline Paraquat and Rotenone oxidize Trx \\
\hline 2-[(1-methylpropyl)dithio]-1H-imidazole (PX-12) oxidizes Trx \\
\hline Trx is a HIF-1a stabilizer \\
\hline Overexpression of Trx leads to the increase in HIF-1a under hypoxic conditions \\
\hline Silencing of Trx decreases vascular endothelial growth factor expression. \\
\hline Selenium supplementation increases TrxR activity \\
\hline Sulforaphane, Erucin, Iberin induce TrxR \\
\hline 1,2-[bis(1,2-benzisoselenazolone-3(2H)-ketone)] ethane (BBSKE) inhibits TrxR \\
\hline Auranofin inhibits TrxR \\
\hline Green tea extracts inhibit TrxR \\
\hline Cyclophosphamide inhibits TrxR \\
\hline Mercury toxicity leads to the selective inhibition of TrxR \\
\hline Estrogen increases Trx, Trx2, and TrxR expression \\
\hline Overexpression of thioredoxin peroxidase II decreases H2O2 \\
\hline Txnip can interfere with Trx/ASK-1 interactions \\
\hline Txnip is an antagonist of Trx \\
\hline Estrogen decreases Txnip expression \\
\hline Histone deacetylase inhibitors upregulate Txnip \\
\hline Glucose increases expression of Txnip \\
\hline
\end{tabular}

\section{Background to a new paradigm for antiestrogen resistance}

Thioredoxin and cell cycle progression/arrest: As we look at the role thioredoxin may

play in antiestrogen resistance, we briefly discuss how estrogen actions are controlled by redox regulation and other interacting proteins that can affect this change in a breast cancer cell's sensitivity to AE treatment and AR resistance.

Thioredoxin appears to play an important role in the redox state of the estrogen receptor. Using the breast cancer cell line ZR-75-1, researchers have shown that when cells were treated with $\mathrm{H}_{2} \mathrm{O}_{2}$, there was a decrease in the levels of $\mathrm{pS} 2$, a gene induced by estrogen. When, however, cells were transfected with thioredoxin, the expression of pS2 was 
restored in the $\mathrm{H}_{2} \mathrm{O}_{2}$-treated cells. ${ }^{106}$ In a study regarding estrogen and congestive heart failure, subcutaneous slow release pellets of estrogen $(0.5 \mathrm{mg} / 60$ day release) offered antioxidative properties. These properties were also associated with an increase in the expression of Trx, TrxR, and TrxR activity. In this form, estrogen also reduced ASK-1 activation, JNK activation, and p38 MAPK, which can all be related to the increase in availability of thioredoxin. These data may show that thioredoxin could be conferring the antioxidative properties that are being linked to estrogen. ${ }^{231}$

In another example of Trx and estrogen interactions, 17ß-estradiol normalizes thioredoxin reductase and glutathione reductase levels in rats that had been ovariectomized. As this was not also seen when 17 $\alpha$-estradiol, which is non-receptor binding, was administered, it has been suggested that glutathione and thioredoxin systems may be stimulated by estrogen through estrogen-receptor positivity. ${ }^{41}$ Endometrial stromal cells not only increase Trx secretions with estrogen treatment in a time-dependent manner, but this effect has been enhanced with an estrogen and progesterone combined treatment. ${ }^{144}$ In the interaction between estrogen and the thioredoxin system in mice, the main component of the thioredoxin system found affected by estrogen was thioredoxininteracting protein (Txnip). While Txnip mRNA levels rise in the initial treatment of mice with estrogen, after 2 hours both mRNA and protein amounts drop approximately 20 per cent, followed by a rise in levels of the other members of the thioredoxin family by 2.5 - to 4 -fold over 24 hours. This reaction was prevented when the mice were treated with the estrogen antagonist ICI 182780, which suggests a role for the estrogen receptor in Txnip decrease upon estrogen treatment. ${ }^{220}$ Inhibition of TrxR reduces estrogen's 
cytoprotection against neurodegeneration. ${ }^{42}$ When this was explored in bovine aortic endothelial cells, it was found that $17 \beta$-estradiol increased the levels of thioredoxin, glutaredoxin, and thioredoxin reductase. When cells were treated with tamoxifen, it inhibited the induction of these three proteins. ${ }^{43}$ Estrogen metabolites 4-OH and 2-OH have been found to be mediated by $\mathrm{p} 450$ CYP1B1 and CYP1A1 respectively. CYP1B1 is induced by Trx in MCF-7 cells, and in MCF-7 cells that have been Trx-1 transfected, there is a decrease in ER $\alpha$ expression. ${ }^{232}$

We have discussed the link between Trx family members and estrogen, and the role ROS plays in the inhibition of Trx actions. We will now discuss other proteins that play a role in our novel paradigm of tamoxifen resistance.

p27: $27^{\mathrm{KIP} 1}$ is a $27 \mathrm{kD}$ protein found in the nucleus, where it is active and inhibits cyclin-dependent kinases (cdks), ${ }^{233}$ most specifically by binding with the cyclin E/cdk2 or cyclin $\mathrm{A} / \mathrm{cdk} 2$ complexes. ${ }^{234,235} \mathrm{p} 27^{\mathrm{KIP} 1}$ (herein called p27) belongs to the CIP/KIP (cdk inhibiting and kinase inhibiting proteins) family and suppresses the $\mathrm{G}_{1}$-to-S phase of the cell cycle $e^{233,236}$ in $\mathrm{G}_{0}$ and early $\mathrm{G}_{1}$, where it inhibits cyclin $\mathrm{E} / \mathrm{cdk} 2$ through binding to the cyclin E protein. ${ }^{235,237}$ Highest concentrations of p27 can be found bound to the cyclin E/cdk2 complex during cell quiescence in normal epithelial cells. ${ }^{238}$ Cyclin E, when bound to the cyclin-dependent kinase cdk2, activates cdk2. If p27 is not available to inhibit this complex, the activated cdk2 phosphorylates the tumor suppressing retinoblastoma protein, which then disassociates from the $\mathrm{E} 2 \mathrm{~F}$ transcription factor, leading to the transcription of genes that allow progression into the $\mathrm{S}$ phase of the cell 
cycle. ${ }^{235,237}$ The phosphorylation of the retinoblastoma protein is necessary for the cell to move from the G1 to the S phase of the cell cycle, and both D-type and E-type cyclins can lead to this phosphorylation. ${ }^{239}$ Cyclins E, A, and D are involved with $\mathrm{G}_{1}$ progression, and p27 can play a dual role when interacting with these cyclins. While unphosphorylated p27 inhibits cell cycle progression through cyclin E/cdk2 and cyclin A/cdk2 binding, ${ }^{237}$ properly phosphorylated p27 can assist in assembling cyclin D with $\mathrm{cdk} 4$ and cdk6, creating complexes that further $\mathrm{G}_{1}$ progression. Many cell lines require high levels of p27 to stay in quiescence, and thus the down regulation of p27 is necessary for cell cycle progression. ${ }^{240}$ There are several ways in which p27 can become inactivated, and thus lose its inhibitory action and promote cell cycle progression. Localization, phosphorylation, and proteolysis are three known factors affecting the activity state of p27. The location of p27 plays an important role in the inhibition of the cell cycle, because while it is inhibiting cell cycle progression it remains bound to the cyclin E/cdk2 complex in the nucleus. However, upon proper phosphorylation, it moves to the cytoplasm as the cell moves into $\mathrm{G}_{1}$, where it can either assemble cyclin $\mathrm{D} / \mathrm{cdk}$ complexes or undergo proteolysis. p27 has been found in the cytoplasm in approximately $40 \%$ of primary breast cancers, and this relocation of p 27 can increase the dedifferentiation of tumors, and decrease the chances for survival. ${ }^{237}$ Phosphorylation of p27 can change the function of the protein. Several phosphorylation sites and their functions are currently known. Phosphorylation at threonine 157 can both impair the nuclear import of p27 and promote the assembly of cyclin D/cdk complexes. ${ }^{241}$ Through phosphorylation at threonine 198, p27 can help a cell survive through autophagy in cellular metabolic stress, and can also promote cyclin D/cdk assembly, with the addition 
of tyrosine phosphorylation. ${ }^{242}$ When E2 binds to the ER, there is as activation of Src, which can lead to phosphorylation of p27 at tyrosines 74 and 88 . This encourages phosphorylation at $\mathrm{T} 187$ as well as reduces the half-life of p27. Tamoxifen also interacts with Src, furthering the role of p27 in breast cancer inhibition. When Src is inhibited, the actions of tamoxifen are enhanced. This shows an important role for Src, and thus p27 phosphorylation, in breast cancer cell survival. ${ }^{243}$

The phosphorylation of $\mathrm{p} 27$ at tyrosines 74,88 , and 89 can also reduce $\mathrm{p} 27$ 's affinity for cdk2. ${ }^{238}$ Cyclin E-cdk2 can phosphorylate p27 at threonine 187, an action that can lead to the marking of p27 to be recognized by its ligase (SCF-type E3), which further leads to the ubiquitylation of p27 and its $26 \mathrm{~S}$ proteasome-related degradation. ${ }^{235,244}$ Serine 10 phosphorylation is necessary for p27 to be transported out of the nucleus, ${ }^{237}$ and in this way assists with ubiquitination (and subsequent proteolysis) of p27 in late G1. In many human cancers, activation of p27 proteolysis appears excessive, with it being seen approximately $41-69 \%$ in breast cancer. ${ }^{237}$

Approximately $60 \%$ of primary human breast cancer and other cancers express a reduced amount of p27 and are associated with poor patient outcome. ${ }^{244}$ Loss of p27 is also correlated with tumor grade increase. ${ }^{245}$ Low concentrations of p27 have been found to be associated with a 3.4-fold increased risk of death $(\mathrm{p}=0.0306)$, and an increase of risk of relapse of 2.7 -fold $(\mathrm{p}=0.01)$. Other studies have shown a decrease in overall survival when there is a low $\mathrm{p} 27$ concentration and high cyclin $E$ content $(R R=2.7, p=0.01){ }^{246}$ Reduced levels of p27 are a poor prognostic factor in several other carcinomas as well, 
including colon, lung, prostate, esophageal, and gastric carcinomas, ${ }^{247}$ and oral dysplasias and carcinomas. ${ }^{248}$

A key to p27 ubiquination is its nuclear export to the cytoplasm. This can be influenced by 27 binding to CRM1. ${ }^{249}$ It has been implied that Jab1 may be a bridging protein between p27 and CRM-1, as treatment of NIH3T3 cells with leptomycin B (a specific CRM-1 nuclear export inhibitor) decreased p27 nuclear export by Jab1 ${ }^{250}$ It also has been shown, however, that CRM-1 binds to 27 at its cdk2 binding site to export it from the nucleus. ${ }^{251}$ We next explore Jab1 as part of our paradigm for tamoxifen resistance.

Jab1: Jab1 (Jun activation domain-binding protein 1) is a $\sim 40 \mathrm{kD}$ protein that was named for its interaction with c-Jun at its activation domain. Jab1 is the $5^{\text {th }}$ subunit in the COP9 signalosome, and is also known as CSN5. ${ }^{252}$ The COP9 signalosome is a known coactivator of the AP-1 transcription factor, ${ }^{123}$ and Jab1 is known to interact with at least 4 other subunits in the COP9 complex; CSNs 1, 2, 4, and 7. ${ }^{253}$ Jab1 stabilizes c-Jun or JunD complexes at their AP-1 binding sites, which allows the specificity of the target gene activation to be increased. When Jab1 interacts with the c-Jun protein, it enhances the binding power of AP-1 complexes that contain c-Jun. This increases AP-1-dependent transcription, which then leads to cell proliferation. ${ }^{123,252}$ Nuclear receptor transcriptional transactivation can be modulated by Jab1, as can be seen with progesterone receptors. The addition of Jab1 can enhance the capability of the progesterone receptor to perform hormone-dependent transactivation. This enhancing ability has also been shown with glucocorticoid, mineralocorticoid, androgenic and estrogenic receptors, and NF-kB. ${ }^{254}$ 
Nuclear receptor binding protein (NRBP) may be a negative regulator of Jab1-mediated functions, as phosphorylation of c-Jun and AP-1 activation is inhibited by the addition of NRBP, and thus may inhibit tumor progression. ${ }^{255}$

There is a difference in action between the smaller Jab1 complex and the larger COP9 complex. Researchers note that a loss of anchorage leads to the downregulation of the smaller Jab1 complex, that when p27 is downregulated the smaller Jab1 complex was upregulated, and that throughout the cell cycle the small Jab1 complex moves between the monomeric state and the COP9 signalosome. ${ }^{216}$

One of the significant common themes with Jab1 is its numerous interactions with multiprotein complexes that appear to be connected to ubiquitin-dependent protein degradation pathways. $^{253} \mathrm{Jab} 1$ interaction with p27 is a good example of this. It has been suggested that Jab1 can lead to cell proliferation through the translocation of $\mathrm{p} 27$ from the nucleus to cytoplasm and accelerating p27 degradation through the ubiquitin/proteosome pathway. ${ }^{256}$ Jab1 has been negatively associated with p27 expression in a variety of cancer cells. The expression of both Jab1 and p27 in breast carcinomas in regards to clinical outcomes has been explored, and it has been found that in $60 \%$ of the carcinomas studied there is a reduced or depleted existence of $\mathrm{p} 27$. Researchers also looked at the possibility of using this information in a prognostic way, and saw that those patients with tumors that were Jab1-negative did not relapse or show signs of disease progress. ${ }^{257}$ Translocation of p27 can occur due to mitogenic stimuli, ${ }^{233}$ and Jab1 has been implicated 
as a major cause for the translocation of $\mathrm{p} 27$ from the nucleus to the cytoplasm. When p27 and Jab1 are cotransfected, there is acceleration in p27 proteolysis. ${ }^{249}$

Vitamin D3 upregulated protein 1 (Txnip) is also a Jab1 inhibitor that blocks the ability of Jab1 to move p27 from the nucleus to the cytoplasm, as well as blocking its co-activation of AP-1. ${ }^{258}$ The proteolysis of $\mathrm{p} 27$ is thought to be mediated by not just Jab1, but by the COP9 signalosome as well. There are at least three other parts of COP9 (namely CSN6, CSN7, and CSN8) which also can lead to the downregulation of p27 when they are expressed ectopically. ${ }^{259}$

In a study of levels of p27 in benign and malignant lesions in 94 randomly selected cases at the University of Texas MD Anderson Cancer Center, fourteen out of seventeen standard nevi cases showed a strong expression of p 27 in over $75 \%$ of the cells. Out of 22 melanoma cases, only 3 showed expression of p27. And out of 30 cases of metastatic melanoma, only 4 were p27 positive. The expression of Jab1 in these same samples was also investigated. Jab1 was expressed in 14 out of 17 cases of standard nevi, and in 18 out of 19 dysplastic nevi, with 11 of those strongly Jab1-positive. While only few of the primary melanoma cases were p 27 positive, approximately $77 \%$ of them were Jab 1 positive. Metastatic melanomas were Jab1 positive in $53 \%$ of the cases. This pattern was seen across different histologic types of melanoma. ${ }^{233}$ This theme of high Jab1 and low p27 in cancer is seen in several studies. ${ }^{257,}{ }^{260-262}$ In breast cancer, there is an increase in Jab1 in adjacent normal cells as compared to normal breast cancer cells. ${ }^{263}$ Interestingly, 
there is initial evidence that cytoplasmic p27 is present in invasive tumors, yet not in noninvasive tumors, presenting the possibility of a role for cytoplasmic p27 in metastasis. ${ }^{264}$

It has been shown that Jab1 and ER $\alpha$ interact (either directly or indirectly) through a finding that Jab1 comimmunoprecipitates with ER $\alpha$. Also, an increase in Jab1 levels is associated with hormone-induced ER $\alpha$ degradation. Curcumin, which inhibits CSNassociated kinase activity and prevents the degradation of ER $\alpha$, increases the amount of coimmunoprecipitated Jab1 and ER $\alpha$, as well as blocked ER $\alpha$ phosphorylations and degradations that are ligand dependent. ${ }^{265}$

It has been presented that Jab1 location is well regulated within the cell, and is present mostly in the nucleus, though there are small amounts in the cytoplasm. The Jab1 signal is also very strong in adult tissues that are terminally differentiated. ${ }^{266}$

Thioredoxin and its proposed role in antiestrogen resistance: With the oxidation that is produced by both estrogen and tamoxifen, the redox nature of proteins cannot be ignored as a possible player in tamoxifen resistance. Tamoxifen-resistant breast cancer tumors show decreased glutathione levels, and it is suggested that the increase in tamoxifen-induced oxidative stress and decreased glutathione levels activate JNK and increase AP-1 actions, leading to growth in the presence of tamoxifen. ${ }^{68}$ As mentioned earlier, tamoxifen inhibits estrogen-induced thioredoxin, glutaredoxin, and thioredoxin reductase. ${ }^{43}$ Also, when cells proliferate in a manner that forms cellular masses, cells are deprived of oxygen and nutrients, which leads to cellular adaptations that allow the 
cancer cell to survive (i.e. the suppression of apoptosis). ${ }^{267} \operatorname{Trx}$ reductase has a variant, labeled TrxR1b, which is thought to influence the assembly of estrogen receptor coactivator complex. As such, it may modulate estrogen signaling. ${ }^{268}$ When doxorubicinresistant small cell carcinoma lung cells are treated with selenium, the result is caspase-3independent apoptosis. While TrxR levels and activity increases with this treatment, the amount of truncated Trx does not change. ${ }^{269}$ These cancer studies on Trx do not observe the oxidative state of the Trx that is being measured, and results such as these could be due to TrxR reducing Trx and restoring its activity.

As mentioned earlier, most studies on Trx and resistance focus on Trx's anti-apoptotic role. Response to docetaxel, a potent anti-cancer drug used with breast cancer patients, has been linked to thioredoxin. In a study on Docetaxel and the gene expression that may predict resistance to the drug, thioredoxin was one of several proteins that, when overexpressed, meant there was a good chance the person would not respond to the anticancer drug. ${ }^{270}$ Trx expression is correlated with platinum-based drug resistance. ${ }^{271}$ High levels of thioredoxin have been associated with resistance to cisdiamminedichloroplatinum (II) (cisplatin), mitomycin C, doxorubicin, and etoposide. To test this association with docetaxel, thioredoxin expression was related to its reaction to estrogen receptor positivity. It was found that patients with ER negative tumors low in thioredoxin showed the highest response to docetaxel treatment (42.3\%) and the lowest response $(0 \%)$ was in patients who had high thioredoxin levels and were estrogen receptor positive. When patients were treated with thioredoxin prior to docetaxel therapy, thioredoxin levels rose upon treatment with the drug. While levels of thioredoxin 
increased equally across cell samples, it was noted that it was the high level of thioredoxin present before docetaxel treatment that confers resistance, not the increase at the time of treatment. ${ }^{272}$ It is thought that thioredoxin may contribute to other anti-cancer drug resistances. When a thioredoxin antisense plasmid was transfected into cisplatinresistant T-cell leukemia cells, sensitivity to cisplatin, as well as several other anticancer drugs, was restored. ${ }^{21}$ When selenium treatment was added to doxorubicin-resistant cells, caspase-3-independent apoptosis occurred. There was also an increase in TrxR protein levels and activity, and truncated Trx increased.

While these studies show the role of Trx as an agonist for chemotherapeutic drug resistance, we suggest that the role Trx plays in other protein actions (outside of reducing the effects of ROS) is affected by the overoxidation of Trx and can play a role in antiestrogen resistance (see Figure 4-LR). We suggest that the oxidative state of cells treated with antiestrogens will add a constant state of oxidative stress, and will create an adaptation in the cellular mechanism that leads to resistance to antiestrogens, namely through an oxidation of thioredoxin.

Jab1 and a possible interaction with thioredoxin: When hepatopoietin (HPO) loses its sulfhydryl oxidase abilities at its cysteine residues, it is no longer able to affect AP-1 activation due to its lack of ability to interact with Jab1. This does not affect HPOs ability to promote growth via the MAPK pathway. ${ }^{273}$ However, this suggests that the sulfhydryl ability of an interacting protein will affect its interaction with Jab1, as may be the case with thioredoxin. Trx has been found to compete with $\mathrm{p} 27$ for binding with Jab1 in 
HEK293T (human embryonic kidney) cells, and through this, negatively regulate p27 degradation. The possibility that Trx could affect Jab1/p27 binding in these cells was explored, and it was found that the addition of Trx to cells altered the direction of Jab1induced p27 level decrease. It was also found that the addition of Trx did not increase levels of p27 when Jab1 was not overexpressed. This led to a hypothesis that Trx competes with $\mathrm{p} 27$ for binding with Jab1. The researchers showed that Trx specifically interacts with the C-terminal of Jab1, while p27 is known to interact with the $\mathrm{N}$-terminal. The hypothesis was that when Trx binds with Jab1, it produces a conformational change that inhibits the binding affinity for $\mathrm{p} 27$. This decrease in binding affinity could then allow p27 to continue to bind to the cyclin E/cdk2 complex, and inhibit cell proliferation. Another Jab1 effect that was inhibited by Trx binding was AP-1 activation. When Jab1 levels were increased, Trx was found to decrease AP-1 activity. Increased Jab1 levels have been found in certain cancers of the pituitary, ovary and breast and in certain lymphomas. Because of the increased Jab1 expression in these tumors, Trx could play an important role in decreasing AP-1 activity, but also in keeping Jab1 from removing p27 from the nucleus. ${ }^{123}$ Figure 5-LR shows this interaction and a possible role for Trx in keeping Jab1 from moving p27 out of the nucleus. The possible oxidation and inactivation of Trx through tamoxifen treatment can lead to an increase in p27 removal from the nucleus by Jab1.

PTPs and thioredoxin: Particularly susceptible to oxidation are protein tyrosine phosphatases (PTPs), including PTEN, PTP1B, cdc25, and low molecular weight PTP. ${ }^{87}$, ${ }^{116}$ Several PTPs have been show to correlate with p27 levels. A downstream molecule in 
the phosphoinositol 3' kinase (PI3K) pathway, protein kinase B (Akt), can phosphorylate p27 at T157 and inhibit its import to the nucleus. This prohibits p27 from inhibiting cell proliferation. ${ }^{274}$ When the PI3K pathway has been activated, as it is in human cancers, it has been found that $\mathrm{p} 27$ concentrations decrease. This effect is reversed by the PI3K inhibitor LY294002, a "kinase-dead" PKB/Akt, or the PI3K phosphatase PTEN. When PI3K activation is opposed by PTEN in specific cell lines, p27 concentrations increase. It has been suggested that PTEN may work in this way through repressing SKP-2, a component of the $\mathrm{SCF}^{\mathrm{SKP} 2}$ ubiquitin ligase. ${ }^{237}$ Overexpression of the PTEN gene increases p27 levels, decreases cyclin D1 levels, inhibits the phosphorylation of Akt, and through these mechanisms inhibits cell growth in MCF-7 cells. ${ }^{275}$ In human mammary epithelial cells (HMEC), activation of the PI3K pathway is necessary for the cell to move from $\mathrm{G} 1$ to $\mathrm{S}$ because of its activation of the cyclin $\mathrm{E} / \mathrm{cdk} 2$ complex. ${ }^{240}$ The $\mathrm{CDC} 25 \mathrm{~A}$ PTP has been linked to cdk2. CDC25 is a dual specificity PTP that dephosphorylates cyclin E-cdk2 inhibitory phosphorylation sites. In this way, CDC25A controls S phase entry and progression. PTP1B has been associated with the Src family kinases, as well as with other pathways. ${ }^{276,277}$ Src has two phosphorylation sites that can be affected by phosphatases. While one is an inhibiting site, the other is an activation site that is autophosphorylated. PTP-BL dephosphorylates Src at this activation site, keeping Src inactivated. ${ }^{278}$ Src binding to PTP1B is proline residue dependent. ${ }^{279}$ When PTP1B is downregulated, a decrease in ERK1/2 phosphorylation has been shown, as well as a dephosphorylation of Src at the inactivation site. ${ }^{277}$ When HEK293 cells are transfected with both Src and TRPV6, a cation channel, the tyrosine phosphorylation that Src imposed on TRPV6 is dephosphorylated by PTP1B. ${ }^{280}$ 
These same PTPs are also reduced by Trx. PTEN can be oxidized by $\mathrm{H}_{2} \mathrm{O}_{2}$, and then reduced by Trx. ${ }^{281}$ CDC25 PTPs are known to react directly with ROS due to their catalytic cysteine residue. This reaction causes an inactivation in the CDC25 enzyme through creating a disulphide that can be reversed by thioredoxin. ${ }^{282}{ }^{283}$ While no data is available for the actions Trx may have on PTP-BL, it is known that PTP-BL contains two cysteine residues that appear to regulate binding, and that this binding capacity is lost

when a reducing treatment is added. ${ }^{284}$ PTP1B has been linked with thioredoxin through a murine study using selenium supplementation. Rats that were fed 75 or $150 \mu \mathrm{g}$ of selenium/kg showed an increase in thioredoxin reductase, as well as other selenoproteins, and a decrease in PTP1B glutathionylation (which inhibits PTP activity). ${ }^{285}$

It is possible that the oxidation of PTPs via the oxidative stress of tamoxifen treatment can play an important role in tamoxifen resistance through lack of interaction with kinases that phosphorylate $\mathrm{p} 27$. In the suggested case of an increase oxidized state in the cell by chronic tamoxifen treatment, oxidized Trx is unable to reduce p27-affecting PTPs, which could play a role in the continued growth of cancer cells in the presence of tamoxifen treatment.

\section{Summary}

The mechanisms of antiestrogen resistance are complex. Here we have presented the data involving Trx and show different ways Trx may have a role in antiestrogen resistance in breast cancer. As cells are chronically exposed to ROS from long-term tamoxifen treatment, they can adapt to this increasing level of ROS and oxidative stress. This can 
lead to oxidation of certain cellular antioxidant systems, such as thioredoxin, causing them to become inactive. The inactivation of the thioredoxin antioxidant family can then affect other proteins such as PTPs or Jab1, or lead to the continued activation of cell signaling pathways such as MAPKs, leading to the activation of transcription factors such as AP-1 or NF- $\mathrm{kB}$ and subsequent cell proliferation. It is in this way that we propose that ROS and the thioredoxin family may play a role in tamoxifen resistance.

\section{Acknowledgments}

The Department of the Defense BCRP-funded project W81XWH-07-1-0417, BC060125, provided funding for this research.

\section{Reference List}

(1) Gadducci A, Biglia N, Sismondi P, Genazzani AR. Breast cancer and sex steroids: critical review of epidemiological, experimental and clinical investigations on etiopathogenesis, chemoprevention and endocrine treatment of breast cancer. Gynecol Endocrinol 2005;20(6):343-360.

(2) Clarke R, Liu MC, Bouker KB et al. Antiestrogen resistance in breast cancer and the role of estrogen receptor signaling. Oncogene 2003;22(47):7316-7339.

(3) Kallio A, Zheng A, Dahllund J, Heiskanen KM, Harkonen P. Role of mitochondria in tamoxifen-induced rapid death of MCF-7 breast cancer cells. Apoptosis 2005;10(6):1395-1410.

(4) IARC. Monographs on the evaluation of the carcinogenic risk of chemicals to human. 1979. Report No.: 21.

(5) IARC. Monographs on the evaluation of hormonal contraception and postmenopausal hormonal therapy. 1999. Report No.: 48. 
(6) Henderson BE, Ross R, Bernstein L. Estrogens as a cause of human cancer: the Richard and Hinda Rosenthal Foundation award lecture. Cancer Res 1988;48(2):246-253.

(7) Roy D, Palangat M, Chen CW et al. Biochemical and molecular changes at the cellular level in response to exposure to environmental estrogen-like chemicals. $J$ Toxicol Environ Health 1997;50(1):1-29.

(8) Roy D, Colerangle JB, Singh KP. Is exposure to environmental or industrial endocrine disrupting estrogen-like chemicals able to cause genomic instability? Front Biosci 1998;3:d913-d921.

(9) Roy D, Cai Q, Felty Q, Narayan S. Estrogen-induced generation of reactive oxygen and nitrogen species, gene damage, and estrogen-dependent cancers. $J$ Toxicol Environ Health B Crit Rev 2007;10(4):235-257.

(10) National Toxicology Program. Federal report on carcinogens. 2002. Report No.: 67 (242).

(11) Clemons M, Goss P. Estrogen and the risk of breast cancer. $N$ Engl J Med 2001;344(4):276-285.

(12) Roy D, Singh KP. Estrogen-induced genetic alterations and breast, endometrial, testicular and prostate cancers. Current Genomics 2004;5:245-257.

(13) IARC. Monographs on the evaluation of combined estrogen-progestogen contraceptives and menopausal therapy. 2005. Report No.: 91.

(14) Yager JD, Davidson NE. Estrogen carcinogenesis in breast cancer. N Engl J Med 2006;354(3):270-282.

(15) Anderson H, Bulun S, Smith I, Dowsett M. Predictors of response to aromatase inhibitors. J Steroid Biochem Mol Biol 2007;106(1-5):49-54.

(16) Goldhirsch A, Glick JH, Gelber RD, Coates AS, Thurlimann B, Senn HJ. Meeting highlights: international expert consensus on the primary therapy of early breast cancer 2005. Ann Oncol 2005;16(10):1569-1583.

(17) Ma CX, Sanchez CG, Ellis MJ. Predicting endocrine therapy responsiveness in breast cancer. Oncology (Williston Park) 2009;23(2):133-142.

(18) Arteaga E, Villaseca P, Bianchi M, Rojas A, Marshall G. Raloxifene is a better antioxidant of low-density lipoprotein than estradiol or tamoxifen in postmenopausal women in vitro. Menopause 2003;10(2):142-146. 
(19) Osborne CK, Shou J, Massarweh S, Schiff R. Crosstalk between estrogen receptor and growth factor receptor pathways as a cause for endocrine therapy resistance in breast cancer. Clin Cancer Res 2005;11(2 Pt 2):865s-870s.

(20) Ellis MJ, Ma C. Letrozole in the neoadjuvant setting: the P024 trial. Breast Cancer Res Treat 2007;105 Suppl 1:33-43.

(21) Marks PA. Thioredoxin in cancer--role of histone deacetylase inhibitors. Semin Cancer Biol 2006;16(6):436-443.

(22) Yokomizo A, Ono M, Nanri H et al. Cellular levels of thioredoxin associated with drug sensitivity to cisplatin, mitomycin $\mathrm{C}$, doxorubicin, and etoposide. Cancer Res 1995;55(19):4293-4296.

(23) Coleman KM, Smith CL. Intracellular signaling pathways: nongenomic actions of estrogens and ligand-independent activation of estrogen receptors. Front Biosci 2001;6:D1379-D1391.

(24) Jakacka M, Ito M, Weiss J, Chien PY, Gehm BD, Jameson JL. Estrogen receptor binding to DNA is not required for its activity through the nonclassical AP1 pathway. J Biol Chem 2001;276(17):13615-13621.

(25) Felty Q, Roy D. Estrogen, mitochondria, and growth of cancer and non-cancer cells. J Carcinog 2005;4(1):1.

(26) Normanno N, Di MM, De ME et al. Mechanisms of endocrine resistance and novel therapeutic strategies in breast cancer. Endocr Relat Cancer 2005;12(4):721-747.

(27) Roy D, Felty Q, Narayan S, Jayakar P. Signature of mitochondria of steroidal hormones-dependent normal and cancer cells: potential molecular targets for cancer therapy. Front Biosci 2007;12:154-173.

(28) Roy D, Felty Q, Narayan S, Jayakar P. Signature of mitochondria of steroidal hormones-dependent normal and cancer cells: potential molecular targets for cancer therapy. Front Biosci 2007;12:154-173.

(29) Felty Q, Roy D. Estrogen, mitochondria, and growth of cancer and non-cancer cells. J Carcinog 2005;4(1):1.

(30) Obrero M, Yu DV, Shapiro DJ. Estrogen receptor-dependent and estrogen receptor-independent pathways for tamoxifen and 4-hydroxytamoxifen-induced programmed cell death. J Biol Chem 2002;277(47):45695-45703. 
(31) Roy D, Liehr JG. Estrogen, DNA damage and mutations. Mutat Res 1999;424(12):107-115.

(32) Felty Q, Xiong WC, Sun D et al. Estrogen-induced mitochondrial reactive oxygen species as signal-transducing messengers. Biochemistry 2005;44(18):6900-6909.

(33) Parkash J, Felty Q, Roy D. Estrogen exerts a spatial and temporal influence on reactive oxygen species generation that precedes calcium uptake in high-capacity mitochondria: implications for rapid nongenomic signaling of cell growth. Biochemistry 2006;45(9):2872-2881.

(34) Rajapakse N, Butterworth M, Kortenkamp A. Detection of DNA strand breaks and oxidized DNA bases at the single-cell level resulting from exposure to estradiol and hydroxylated metabolites. Environ Mol Mutagen 2005;45(4):397404.

(35) Felty Q, Singh KP, Roy D. Estrogen-induced G1/S transition of G0-arrested estrogen-dependent breast cancer cells is regulated by mitochondrial oxidant signaling. Oncogene 2005;24(31):4883-4893.

(36) Abplanalp W, Scheiber MD, Moon K, Kessel B, Liu JH, Subbiah MT. Evidence for the role of high density lipoproteins in mediating the antioxidant effect of estrogens. Eur J Endocrinol 2000;142(1):79-83.

(37) Cheng X, Shimizu I, Yuan Y et al. Effects of estradiol and progesterone on tumor necrosis factor alpha-induced apoptosis in human hepatoma HuH-7 cells. Life Sci 2006;79(21):1988-1994.

(38) Roy D, Weisz J, Liehr JG. The O-methylation of 4-hydroxyestradiol is inhibited by 2-hydroxyestradiol: implications for estrogen-induced carcinogenesis. Carcinogenesis 1990;11(3):459-462.

(39) Szent-Gyorgyi A. Charge transfer and electronic mobility. Proc Natl Acad Sci U S A 1967;58(5):2012-2014.

(40) Sunyer T, Lewis J, Collin-Osdoby P, Osdoby P. Estrogen's bone-protective effects may involve differential IL-1 receptor regulation in human osteoclast-like cells. J Clin Invest 1999;103(10):1409-1418.

(41) Lean JM, Davies JT, Fuller K et al. A crucial role for thiol antioxidants in estrogen-deficiency bone loss. J Clin Invest 2003;112(6):915-923.

(42) Lee SY, Andoh T, Murphy DL, Chiueh CC. 17beta-estradiol activates ICI 182,780-sensitive estrogen receptors and cyclic GMP-dependent thioredoxin expression for neuroprotection. FASEB J 2003;17(8):947-948. 
(43) Ejima K, Nanri H, Araki M, Uchida K, Kashimura M, Ikeda M. 17beta-estradiol induces protein thiol/disulfide oxidoreductases and protects cultured bovine aortic endothelial cells from oxidative stress. Eur J Endocrinol 1999;140(6):608-613.

(44) Kato S. Function of estrogen receptor (ER) in gene expression. Jpn J Clin Oncol 1999;29(7):321-322.

(45) Graham JD, Bain DL, Richer JK, Jackson TA, Tung L, Horwitz KB. Thoughts on tamoxifen resistant breast cancer. Are coregulators the answer or just a red herring? J Steroid Biochem Mol Biol 2000;74(5):255-259.

(46) Custodio JB, Moreno AJ, Wallace KB. Tamoxifen inhibits induction of the mitochondrial permeability transition by $\mathrm{Ca} 2+$ and inorganic phosphate. Toxicol Appl Pharmacol 1998;152(1):10-17.

(47) Kuohung W, Shwaery GT, Keaney JF, Jr. Tamoxifen, esterified estradiol, and physiologic concentrations of estradiol inhibit oxidation of low-density lipoprotein by endothelial cells. Am J Obstet Gynecol 2001;184(6):1060-1063.

(48) Ek RO, Yildiz Y, Cecen S, Yenisey C, Kavak T. Effects of tamoxifen on myocardial ischemia-reperfusion injury model in ovariectomized rats. Mol Cell Biochem 2008;308(1-2):227-235.

(49) Wakade C, Khan MM, De Sevilla LM, Zhang QG, Mahesh VB, Brann DW. Tamoxifen neuroprotection in cerebral ischemia involves attenuation of kinase activation and superoxide production and potentiation of mitochondrial superoxide dismutase. Endocrinology 2008;149(1):367-379.

(50) Jain S, Saxena D, Kumar PG, Koide SS, Laloraya M. Effect of estradiol and selected antiestrogens on pro- and antioxidant pathways in mammalian uterus. Contraception 1999;60(2):111-118.

(51) Leguene C, Clavere P, Jore D, Gardes-Albert M. [Radiolytic oxidation of tamoxifen with the free radicals OH- and/or HO2-]. Can J Physiol Pharmacol 2001;79(2):184-188.

(52) Kallio A, Zheng A, Dahllund J, Heiskanen KM, Harkonen P. Role of mitochondria in tamoxifen-induced rapid death of MCF-7 breast cancer cells. Apoptosis 2005;10(6):1395-1410.

(53) Tabassum H, Parvez S, Rehman H, Banerjee BD, Raisuddin S. Catechin as an antioxidant in liver mitochondrial toxicity: Inhibition of tamoxifen-induced protein oxidation and lipid peroxidation. J Biochem Mol Toxicol 2007;21(3):110117. 
(54) Dietze EC, Caldwell LE, Grupin SL, Mancini M, Seewaldt VL. Tamoxifen but not 4-hydroxytamoxifen initiates apoptosis in p53(-) normal human mammary epithelial cells by inducing mitochondrial depolarization. J Biol Chem 2001;276(7):5384-5394.

(55) Nazarewicz RR, Zenebe WJ, Parihar A et al. Tamoxifen induces oxidative stress and mitochondrial apoptosis via stimulating mitochondrial nitric oxide synthase. Cancer Res 2007;67(3):1282-1290.

(56) Kushnareva Y, Murphy AN, Andreyev A. Complex I-mediated reactive oxygen species generation: modulation by cytochrome c and NAD $(\mathrm{P})+$ oxidationreduction state. Biochem J 2002;368(Pt 2):545-553.

(57) Lee YS, Kang YS, Lee SH, Kim JA. Role of NAD(P)H oxidase in the tamoxifeninduced generation of reactive oxygen species and apoptosis in HepG2 human hepatoblastoma cells. Cell Death Differ 2000;7(10):925-932.

(58) Wlassoff WA, Albright CD, Sivashinski MS, Ivanova A, Appelbaum JG, Salganik RI. Hydrogen peroxide overproduced in breast cancer cells can serve as an anticancer prodrug generating apoptosis-stimulating hydroxyl radicals under the effect of tamoxifen-ferrocene conjugate. J Pharm Pharmacol 2007;59(11):1549-1553.

(59) Rey JR, Cervino EV, Rentero ML, Crespo EC, Alvaro AO, Casillas M. Raloxifene: mechanism of action, effects on bone tissue, and applicability in clinical traumatology practice. Open Orthop J 2009;3:14-21.

(60) Osborne CK, Wakeling A, Nicholson RI. Fulvestrant: an oestrogen receptor antagonist with a novel mechanism of action. Br J Cancer 2004;90 Suppl 1:S2S6.

(61) Dowers TS, Qin ZH, Thatcher GR, Bolton JL. Bioactivation of Selective Estrogen Receptor Modulators (SERMs). Chem Res Toxicol 2006;19(9):1125-1137.

(62) Qin Z, Kastrati I, Ashgodom RT et al. Structural modulation of oxidative metabolism in design of improved benzothiophene selective estrogen receptor modulators. Drug Metab Dispos 2009;37(1):161-169.

(63) Bajetta E, Zilembo N, Bichisao E. Aromatase inhibitors in the treatment of postmenopausal breast cancer. Drugs Aging 1999;15(4):271-283.

(64) Choueiri TK, Alemany CA, bou-Jawde RM, Budd GT. Role of aromatase inhibitors in the treatment of breast cancer. Clin Ther 2004;26(8):1199-1214. 
(65) Ye Q, Bodell WJ. Production of 8-hydroxy-2'-deoxguanosine in DNA by microsomal activation of tamoxifen and 4-hydroxytamoxifen. Carcinogenesis 1996;17(8):1747-1750.

(66) Okubo T, Nagai F, Ushiyama K et al. DNA cleavage and 8hydroxydeoxyguanosine formation caused by tamoxifen derivatives in vitro. Cancer Lett 1998;122(1-2):9-15.

(67) Montano MM, Katzenellenbogen BS. The quinone reductase gene: a unique estrogen receptor-regulated gene that is activated by antiestrogens. Proc Natl Acad Sci U S A 1997;94(6):2581-2586.

(68) Schiff R, Reddy P, Ahotupa M et al. Oxidative stress and AP-1 activity in tamoxifen-resistant breast tumors in vivo. J Natl Cancer Inst 2000;92(23):19261934.

(69) Clarke R, Liu MC, Bouker KB et al. Antiestrogen resistance in breast cancer and the role of estrogen receptor signaling. Oncogene 2003;22(47):7316-7339.

(70) Dowsett M, Johnston S, Martin LA et al. Growth factor signalling and response to endocrine therapy: the Royal Marsden Experience. Endocr Relat Cancer 2005;12 Suppl 1:S113-S117.

(71) Normanno N, Di MM, De ME et al. Mechanisms of endocrine resistance and novel therapeutic strategies in breast cancer. Endocr Relat Cancer 2005;12(4):721-747.

(72) Miller WR. Identification and mechanisms of endocrine resistance. Breast Cancer Res 2008;10 Suppl 4:S19.

(73) Clarke R, Leonessa F, Welch JN, Skaar TC. Cellular and molecular pharmacology of antiestrogen action and resistance. Pharmacol Rev 2001;53(1):25-71.

(74) Musgrove EA, Sutherland RL. Biological determinants of endocrine resistance in breast cancer. Nat Rev Cancer 2009;9(9):631-643.

(75) Kurebayashi J, Okubo S, Yamamoto Y, Sonoo H. Inhibition of HER1 signaling pathway enhances antitumor effect of endocrine therapy in breast cancer. Breast Cancer 2004;11(1):38-41.

(76) Chu I, Blackwell K, Chen S, Slingerland J. The dual ErbB1/ErbB2 inhibitor, lapatinib (GW572016), cooperates with tamoxifen to inhibit both cell proliferation- and estrogen-dependent gene expression in antiestrogen-resistant breast cancer. Cancer Res 2005;65(1):18-25. 
(77) Nicholson RI, Hutcheson IR, Knowlden JM et al. Nonendocrine pathways and endocrine resistance: observations with antiestrogens and signal transduction inhibitors in combination. Clin Cancer Res 2004;10(1 Pt 2):346S-354S.

(78) Cui Y, Parra I, Zhang M et al. Elevated expression of mitogen-activated protein kinase phosphatase 3 in breast tumors: a mechanism of tamoxifen resistance. Cancer Res 2006;66(11):5950-5959.

(79) Schafer FQ, Buettner GR. Redox environment of the cell as viewed through the redox state of the glutathione disulfide/glutathione couple. Free Radic Biol Med 2001;30(11):1191-1212.

(80) Sohn KC, Jang S, Choi DK et al. Effect of thioredoxin reductase 1 on glucocorticoid receptor activity in human outer root sheath cells. Biochem Biophys Res Commun 2007;356(3):810-815.

(81) Valko M, Leibfritz D, Moncol J, Cronin MT, Mazur M, Telser J. Free radicals and antioxidants in normal physiological functions and human disease. Int $J$ Biochem Cell Biol 2007;39(1):44-84.

(82) Genestra M. Oxyl radicals, redox-sensitive signalling cascades and antioxidants. Cell Signal 2007;19(9):1807-1819.

(83) Fruehauf JP, Meyskens FL, Jr. Reactive oxygen species: a breath of life or death? Clin Cancer Res 2007;13(3):789-794.

(84) Trachootham D, Alexandre J, Huang P. Targeting cancer cells by ROS-mediated mechanisms: a radical therapeutic approach? Nat Rev Drug Discov 2009;8(7):579-591.

(85) Azad N, Rojanasakul Y, Vallyathan V. Inflammation and lung cancer: roles of reactive oxygen/nitrogen species. J Toxicol Environ Health B Crit Rev 2008;11(1):1-15.

(86) Zhang DX, Gutterman DD. Mitochondrial reactive oxygen species-mediated signaling in endothelial cells. Am J Physiol Heart Circ Physiol 2007;292(5):H2023-H2031.

(87) Salmeen A, Barford D. Functions and mechanisms of redox regulation of cysteine-based phosphatases. Antioxid Redox Signal 2005;7(5-6):560-577.

(88) Valko M, Rhodes CJ, Moncol J, Izakovic M, Mazur M. Free radicals, metals and antioxidants in oxidative stress-induced cancer. Chem Biol Interact 2006;160(1):1-40. 
(89) Koehler CM, Beverly KN, Leverich EP. Redox pathways of the mitochondrion. Antioxid Redox Signal 2006;8(5-6):813-822.

(90) Ullrich V, Kissner R. Redox signaling: bioinorganic chemistry at its best. J Inorg Biochem 2006;100(12):2079-2086.

(91) Koehler CM, Beverly KN, Leverich EP. Redox pathways of the mitochondrion. Antioxid Redox Signal 2006;8(5-6):813-822.

(92) Cooper CE, Patel RP, Brookes PS, rley-Usmar VM. Nanotransducers in cellular redox signaling: modification of thiols by reactive oxygen and nitrogen species. Trends Biochem Sci 2002;27(10):489-492.

(93) Lv X, Wang N, Su L, Zhang S, Miao J. Inhibition of PC-PLC blocked the survival of mouse neural cells by up-regulating the expression of integrin beta4 and $\mathrm{Rb}$. Dev Neurosci 2006;28(6):499-504.

(94) Park IJ, Hwang JT, Kim YM, Ha J, Park OJ. Differential modulation of AMPK signaling pathways by low or high levels of exogenous reactive oxygen species in colon cancer cells. Ann N Y Acad Sci 2006;1091:102-109.

(95) Thannickal VJ, Fanburg BL. Reactive oxygen species in cell signaling. Am J Physiol Lung Cell Mol Physiol 2000;279(6):L1005-L1028.

(96) Fruehauf JP, Meyskens FL, Jr. Reactive oxygen species: a breath of life or death? Clin Cancer Res 2007;13(3):789-794.

(97) Valko M, Rhodes CJ, Moncol J, Izakovic M, Mazur M. Free radicals, metals and antioxidants in oxidative stress-induced cancer. Chem Biol Interact 2006;160(1):1-40.

(98) Valko M, Leibfritz D, Moncol J, Cronin MT, Mazur M, Telser J. Free radicals and antioxidants in normal physiological functions and human disease. Int $J$ Biochem Cell Biol 2007;39(1):44-84.

(99) Hwang YS, Jeong M, Park JS et al. Interleukin-1beta stimulates IL-8 expression through MAP kinase and ROS signaling in human gastric carcinoma cells. Oncogene 2004;23(39):6603-6611.

(100) Roy D, Sarkar S, Felty Q. Levels of IL-1 beta control stimulatory/inhibitory growth of cancer cells. Front Biosci 2006;11:889-898.

(101) Lin CW, Yang LY, Shen SC, Chen YC. IGF-I plus E2 induces proliferation via activation of ROS-dependent ERKs and JNKs in human breast carcinoma cells. $J$ Cell Physiol 2007;212(3):666-674. 
(102) Schauen M, Spitkovsky D, Schubert J, Fischer JH, Hayashi J, Wiesner RJ. Respiratory chain deficiency slows down cell-cycle progression via reduced ROS generation and is associated with a reduction of $\mathrm{p} 21 \mathrm{CIP} 1 / \mathrm{WAF} 1 . J$ Cell Physiol 2006;209(1):103-112.

(103) Somasundaram S, Edmund NA, Moore DT, Small GW, Shi YY, Orlowski RZ. Dietary curcumin inhibits chemotherapy-induced apoptosis in models of human breast cancer. Cancer Res 2002;62(13):3868-3875.

(104) Block KI, Koch AC, Mead MN, Tothy PK, Newman RA, Gyllenhaal C. Impact of antioxidant supplementation on chemotherapeutic toxicity: a systematic review of the evidence from randomized controlled trials. Int J Cancer 2008;123(6):12271239.

(105) Du J, Daniels DH, Asbury C et al. Mitochondrial production of reactive oxygen species mediate dicumarol-induced cytotoxicity in cancer cells. J Biol Chem 2006;281(49):37416-37426.

(106) Hayashi S, Hajiro-Nakanishi K, Makino Y, Eguchi H, Yodoi J, Tanaka H. Functional modulation of estrogen receptor by redox state with reference to thioredoxin as a mediator. Nucleic Acids Res 1997;25(20):4035-4040.

(107) Kitagawa H, Yamaoka I, Akimoto C et al. A reduction state potentiates the glucocorticoid response through receptor protein stabilization. Genes Cells 2007;12(11):1281-1287.

(108) Atsriku C, Benz CC, Scott GK, Gibson BW, Baldwin MA. Quantification of cysteine oxidation in human estrogen receptor by mass spectrometry. Anal Chem 2007;79(8):3083-3090.

(109) Carriere A, Galinier A, Fernandez Y, Carmona MC, Penicaud L, Casteilla L. [Physiological and physiopathological consequences of mitochondrial reactive oxygen species]. Med Sci (Paris) 2006;22(1):47-53.

(110) Greene EL, Farell G, Yu S, Matthews T, Kumar V, Lieske JC. Renal cell adaptation to oxalate. Urol Res 2005;33(5):340-348.

(111) Scheele C, Nielsen S, Pedersen BK. ROS and myokines promote muscle adaptation to exercise. Trends Endocrinol Metab 2009;20(3):95-99.

(112) Chen WQ, Shen W, Shen DM. [The changes of ROS and mitochondria membrane potential in HepG2 cells on the pressure of cisplatin]. Zhonghua Gan Zang Bing Za Zhi 2005;13(7):531-533. 
(113) Mates JM, Segura JA, Alonso FJ, Marquez J. Intracellular redox status and oxidative stress: implications for cell proliferation, apoptosis, and carcinogenesis. Arch Toxicol 2008;82(5):273-299.

(114) Chiarugi P. PTPs versus PTKs: the redox side of the coin. Free Radic Res 2005;39(4):353-364.

(115) Salmeen A, Barford D. Functions and mechanisms of redox regulation of cysteine-based phosphatases. Antioxid Redox Signal 2005;7(5-6):560-577.

(116) Chiarugi P, Buricchi F. Protein tyrosine phosphorylation and reversible oxidation: two cross-talking posttranslation modifications. Antioxid Redox Signal 2007;9(1):1-24.

(117) Kang SW. Two axes in platelet-derived growth factor signaling: tyrosine phosphorylation and reactive oxygen species. Cell Mol Life Sci 2007;64(5):533541.

(118) Chiarugi P, Cirri P. Redox regulation of protein tyrosine phosphatases during receptor tyrosine kinase signal transduction. Trends Biochem Sci 2003;28(9):509514.

(119) Chiarugi P, Fiaschi T, Taddei ML et al. Two vicinal cysteines confer a peculiar redox regulation to low molecular weight protein tyrosine phosphatase in response to platelet-derived growth factor receptor stimulation. J Biol Chem 2001;276(36):33478-33487.

(120) Savitsky PA, Finkel T. Redox regulation of Cdc25C.J Biol Chem 2002;277(23):20535-20540.

(121) Barrett WC, DeGnore JP, Konig S et al. Regulation of PTP1B via glutathionylation of the active site cysteine 215. Biochemistry 1999;38(20):66996705 .

(122) Tonks NK. Redox redux: revisiting PTPs and the control of cell signaling. Cell 2005;121(5):667-670.

(123) Hwang CY, Ryu YS, Chung MS et al. Thioredoxin modulates activator protein 1 (AP-1) activity and $\mathrm{p} 27 \mathrm{Kip} 1$ degradation through direct interaction with Jab1. Oncogene 2004;23(55):8868-8875.

(124) Dennery PA. Effects of oxidative stress on embryonic development. Birth Defects Res C Embryo Today 2007;81(3):155-162. 
(125) Storz P. Reactive oxygen species in tumor progression. Front Biosci 2005;10:1881-1896.

(126) Felty Q, Roy D. Mitochondrial signals to nucleus regulate estrogen-induced cell growth. Med Hypotheses 2005;64(1):133-141.

(127) Gloire G, Legrand-Poels S, Piette J. NF-kappaB activation by reactive oxygen species: fifteen years later. Biochem Pharmacol 2006;72(11):1493-1505.

(128) Peiro C, Matesanz N, Nevado J et al. Glycosylated human oxyhaemoglobin activates nuclear factor-kappaB and activator protein-1 in cultured human aortic smooth muscle. Br J Pharmacol 2003;140(4):681-690.

(129) Meyskens FL, Jr., McNulty SE, Buckmeier JA et al. Aberrant redox regulation in human metastatic melanoma cells compared to normal melanocytes. Free Radic Biol Med 2001;31(6):799-808.

(130) Dumont JA, Bitonti AJ, Wallace CD, Baumann RJ, Cashman EA, Cross-Doersen DE. Progression of MCF-7 breast cancer cells to antiestrogen-resistant phenotype is accompanied by elevated levels of AP-1 DNA-binding activity. Cell Growth Differ 1996;7(3):351-359.

(131) Johnston SR, Lu B, Scott GK et al. Increased activator protein-1 DNA binding and c-Jun NH2-terminal kinase activity in human breast tumors with acquired tamoxifen resistance. Clin Cancer Res 1999;5(2):251-256.

(132) Peralta EA, Viegas ML, Louis S, Engle DL, Dunnington GL. Effect of vitamin E on tamoxifen-treated breast cancer cells. Surgery 2006;140(4):607-614.

(133) Nguyen P, Awwad RT, Smart DD, Spitz DR, Gius D. Thioredoxin reductase as a novel molecular target for cancer therapy. Cancer Lett 2006;236(2):164-174.

(134) Kondo N, Nakamura H, Masutani H, Yodoi J. Redox regulation of human thioredoxin network. Antioxid Redox Signal 2006;8(9-10):1881-1890.

(135) Forman HJ, Fukuto JM, Torres M. Redox signaling: thiol chemistry defines which reactive oxygen and nitrogen species can act as second messengers. Am J Physiol Cell Physiol 2004;287(2):C246-C256.

(136) Hall G, Emsley J. Structure of human thioredoxin exhibits a large conformational change. Protein Sci 2010.

(137) Das KC, White CW. Redox systems of the cell: possible links and implications. Proc Natl Acad Sci U S A 2002;99(15):9617-9618. 
(138) Nordberg J, Arner ES. Reactive oxygen species, antioxidants, and the mammalian thioredoxin system. Free Radic Biol Med 2001;31(11):1287-1312.

(139) Arner ES, Holmgren A. Physiological functions of thioredoxin and thioredoxin reductase. Eur J Biochem 2000;267(20):6102-6109.

(140) Demizu Y, Sasaki R, Trachootham D et al. Alterations of cellular redox state during NNK-induced malignant transformation and resistance to radiation. Antioxid Redox Signal 2008;10(5):951-961.

(141) Forman HJ, Fukuto JM, Torres M. Redox signaling: thiol chemistry defines which reactive oxygen and nitrogen species can act as second messengers. Am J Physiol Cell Physiol 2004;287(2):C246-C256.

(142) Powis G, Montfort WR. Properties and biological activities of thioredoxins. Annu Rev Biophys Biomol Struct 2001;30:421-455.

(143) Turunen N, Karihtala P, Mantyniemi A et al. Thioredoxin is associated with proliferation, $\mathrm{p} 53$ expression and negative estrogen and progesterone receptor status in breast carcinoma. APMIS 2004;112(2):123-132.

(144) Maruyama T, Sachi Y, Furuke K et al. Induction of thioredoxin, a redox-active protein, by ovarian steroid hormones during growth and differentiation of endometrial stromal cells in vitro. Endocrinology 1999;140(1):365-372.

(145) Didier C, Kerblat I, Drouet C, Favier A, Beani JC, Richard MJ. Induction of thioredoxin by ultraviolet-A radiation prevents oxidative-mediated cell death in human skin fibroblasts. Free Radic Biol Med 2001;31(5):585-598.

(146) Perl A, Banki K. Genetic and metabolic control of the mitochondrial transmembrane potential and reactive oxygen intermediate production in HIV disease. Antioxid Redox Signal 2000;2(3):551-573.

(147) Chang EY, Son SK, Ko HS, Baek SH, Kim JH, Kim JR. Induction of apoptosis by the overexpression of an alternative splicing variant of mitochondrial thioredoxin reductase. Free Radic Biol Med 2005;39(12):1666-1675.

(148) Arai RJ, Masutani H, Yodoi J et al. Nitric oxide induces thioredoxin-1 nuclear translocation: possible association with the p21Ras survival pathway. Biochem Biophys Res Commun 2006;348(4):1254-1260.

(149) Rundlof AK, Arner ES. Regulation of the mammalian selenoprotein thioredoxin reductase 1 in relation to cellular phenotype, growth, and signaling events. Antioxid Redox Signal 2004;6(1):41-52. 
(150) McEligot AJ, Yang S, Meyskens FL, Jr. Redox regulation by intrinsic species and extrinsic nutrients in normal and cancer cells. Annu Rev Nutr 2005;25:261-295.

(151) Dammeyer P, Damdimopoulos AE, Nordman T, Jimenez A, Miranda-Vizuete A, Arner ES. Induction of cell membrane protrusions by the N-terminal glutaredoxin domain of a rare splice variant of human thioredoxin reductase 1. J Biol Chem 2008;283(5):2814-2821.

(152) Urig S, Becker K. On the potential of thioredoxin reductase inhibitors for cancer therapy. Semin Cancer Biol 2006;16(6):452-465.

(153) Bjornstedt M, Xue J, Huang W, Akesson B, Holmgren A. The thioredoxin and glutaredoxin systems are efficient electron donors to human plasma glutathione peroxidase. J Biol Chem 1994;269(47):29382-29384.

(154) Lemarechal H, Anract P, Beaudeux JL, Bonnefont-Rousselot D, Ekindjian OG, Borderie D. Impairment of thioredoxin reductase activity by oxidative stress in human rheumatoid synoviocytes. Free Radic Res 2007;41(6):688-698.

(155) Ramachandiran S, Hansen JM, Jones DP, Richardson JR, Miller GW. Divergent mechanisms of paraquat, MPP + , and rotenone toxicity: oxidation of thioredoxin and caspase-3 activation. Toxicol Sci 2007;95(1):163-171.

(156) Huber K, Patel P, Zhang L et al. 2-[(1-methylpropyl)dithio]-1H-imidazole inhibits tubulin polymerization through cysteine oxidation. Mol Cancer Ther 2008;7(1):143-151.

(157) Liyanage NP, Fernando MR, Lou MF. Regulation of the bioavailability of thioredoxin in the lens by a specific thioredoxin-binding protein (TBP-2). Exp Eye Res 2007;85(2):270-279.

(158) Makino Y, Okamoto K, Yoshikawa $\mathrm{N}$ et al. Thioredoxin: a redox-regulating cellular cofactor for glucocorticoid hormone action. Cross talk between endocrine control of stress response and cellular antioxidant defense system. J Clin Invest 1996;98(11):2469-2477.

(159) Haendeler J, Tischler V, Hoffmann J, Zeiher AM, Dimmeler S. Low doses of reactive oxygen species protect endothelial cells from apoptosis by increasing thioredoxin-1 expression. FEBS Lett 2004;577(3):427-433.

(160) Gon Y, Sasada T, Matsui M et al. Expression of thioredoxin in bleomycin-injured airway epithelium: possible role of protection against bleomycin induced epithelial injury. Life Sci 2001;68(16):1877-1888. 
(161) Kaimul AM, Nakamura H, Tanito M, Yamada K, Utsumi H, Yodoi J. Thioredoxin-1 suppresses lung injury and apoptosis induced by diesel exhaust particles (DEP) by scavenging reactive oxygen species and by inhibiting DEPinduced downregulation of Akt. Free Radic Biol Med 2005;39(12):1549-1559.

(162) Dai J, Wang X, Feng J et al. Regulatory role of thioredoxin in homocysteineinduced monocyte chemoattractant protein-1 secretion in monocytes/macrophages. FEBS Lett 2008;582(28):3893-3898.

(163) Kuhara T, Watanabe D, Akita Y et al. Thioredoxin upregulation by 5aminolaevulinic acid-based photodynamic therapy in human skin squamous cell carcinoma cell line. Photodermatol Photoimmunol Photomed 2008;24(3):142146.

(164) Berggren MI, Husbeck B, Samulitis B, Baker AF, Gallegos A, Powis G. Thioredoxin peroxidase-1 (peroxiredoxin-1) is increased in thioredoxin-1 transfected cells and results in enhanced protection against apoptosis caused by hydrogen peroxide but not by other agents including dexamethasone, etoposide, and doxorubicin. Arch Biochem Biophys 2001;392(1):103-109.

(165) Soini Y, Kahlos K, Napankangas U et al. Widespread expression of thioredoxin and thioredoxin reductase in non-small cell lung carcinoma. Clin Cancer Res 2001;7(6):1750-1757.

(166) Nonn L, Berggren M, Powis G. Increased expression of mitochondrial peroxiredoxin-3 (thioredoxin peroxidase-2) protects cancer cells against hypoxia and drug-induced hydrogen peroxide-dependent apoptosis. Mol Cancer Res 2003;1(9):682-689.

(167) Wang W, Wang S, Howie AF, Beckett GJ, Mithen R, Bao Y. Sulforaphane, erucin, and iberin up-regulate thioredoxin reductase 1 expression in human MCF7 cells. J Agric Food Chem 2005;53(5):1417-1421.

(168) Bacon JR, Plumb GW, Howie AF, Beckett GJ, Wang W, Bao Y. Dual action of sulforaphane in the regulation of thioredoxin reductase and thioredoxin in human HepG2 and Caco-2 cells. J Agric Food Chem 2007;55(4):1170-1176.

(169) Karunasinghe N, Ferguson LR, Tuckey J, Masters J. Hemolysate thioredoxin reductase and glutathione peroxidase activities correlate with serum selenium in a group of New Zealand men at high prostate cancer risk. J Nutr 2006;136(8):22322235 .

(170) Carvalho CM, Chew EH, Hashemy SI, Lu J, Holmgren A. Inhibition of the human thioredoxin system. A molecular mechanism of mercury toxicity. J Biol Chem 2008;283(18):11913-11923. 
(171) Imaoka H, Hoshino T, Takei S et al. Effects of thioredoxin on established airway remodeling in a chronic antigen exposure asthma model. Biochem Biophys Res Commun 2007;360(3):525-530.

(172) Kawasaki K, Nishio A, Nakamura $\mathrm{H}$ et al. Helicobacter felis-induced gastritis was suppressed in mice overexpressing thioredoxin-1. Lab Invest 2005;85(9):11041117.

(173) Kurimoto C, Kawano S, Tsuji G et al. Thioredoxin may exert a protective effect against tissue damage caused by oxidative stress in salivary glands of patients with Sjogren's syndrome. J Rheumatol 2007;34(10):2035-2043.

(174) Hokamaki J, Kawano H, Soejima H et al. Plasma thioredoxin levels in patients with unstable angina. Int J Cardiol 2005;99(2):225-231.

(175) Rancourt RC, Lee RL, O'Neill H, Accurso FJ, White CW. Reduced thioredoxin increases proinflammatory cytokines and neutrophil influx in rat airways: modulation by airway mucus. Free Radic Biol Med 2007;42(9):1441-1453.

(176) Lee RL, Rancourt RC, del VG et al. Thioredoxin and dihydrolipoic acid inhibit elastase activity in cystic fibrosis sputum. Am J Physiol Lung Cell Mol Physiol 2005;289(5):L875-L882.

(177) Hoshino T, Okamoto M, Takei S, Sakazaki Y, Iwanaga T, Aizawa H. Redoxregulated mechanisms in asthma. Antioxid Redox Signal 2008;10(4):769-783.

(178) Wu XW, Teng ZY, Jiang LH et al. Human thioredoxin exerts cardioprotective effect and attenuates reperfusion injury in rats partially via inhibiting apoptosis. Chin Med J (Engl ) 2008;121(9):819-826.

(179) Hoshino Y, Shioji K, Nakamura H, Masutani H, Yodoi J. From oxygen sensing to heart failure: role of thioredoxin. Antioxid Redox Signal 2007;9(6):689-699.

(180) Patel JM, Hu H, Lu L et al. Thioredoxin as a biomarker for graft rejection in lung transplant recipients. Biomarkers 2008;13(5):486-495.

(181) Noike T, Miwa S, Soeda J, Kobayashi A, Miyagawa S. Increased expression of thioredoxin-1, vascular endothelial growth factor, and redox factor-1 is associated with poor prognosis in patients with liver metastasis from colorectal cancer. Hum Pathol 2008;39(2):201-208.

(182) Liu GH, Qu J, Shen X. Thioredoxin-mediated negative autoregulation of peroxisome proliferator-activated receptor alpha transcriptional activity. Mol Biol Cell 2006;17(4):1822-1833. 
(183) Chen Y, Yu M, Jones DP, Greenamyre JT, Cai J. Protection against oxidantinduced apoptosis by mitochondrial thioredoxin in SH-SY5Y neuroblastoma cells. Toxicol Appl Pharmacol 2006;216(2):256-262.

(184) Yamada T, Iwasaki Y, Nagata K et al. Thioredoxin-1 protects against hyperoxiainduced apoptosis in cells of the alveolar walls. Pulm Pharmacol Ther 2007;20(6):650-659.

(185) Xu JW, Ikeda K, Yamori Y. Inhibitory effect of polyphenol cyanidin on TNFalpha-induced apoptosis through multiple signaling pathways in endothelial cells. Atherosclerosis 2007;193(2):299-308.

(186) Tan A, Nakamura H, Kondo $\mathrm{N}$ et al. Thioredoxin-1 attenuates indomethacininduced gastric mucosal injury in mice. Free Radic Res 2007;41(8):861-869.

(187) Chen XP, Liu S, Tang WX, Chen ZW. Nuclear thioredoxin-1 is required to suppress cisplatin-mediated apoptosis of MCF-7 cells. Biochem Biophys Res Coтmun 2007;361(2):362-366.

(188) Marzano C, Gandin V, Folda A, Scutari G, Bindoli A, Rigobello MP. Inhibition of thioredoxin reductase by auranofin induces apoptosis in cisplatin-resistant human ovarian cancer cells. Free Radic Biol Med 2007;42(6):872-881.

(189) Lan L, Zhao F, Wang Y, Zeng H. The mechanism of apoptosis induced by a novel thioredoxin reductase inhibitor in A549 cells: possible involvement of nuclear factor-kappaB-dependent pathway. Eur J Pharmacol 2007;555(2-3):83-92.

(190) Wang X, Zhang J, Xu T. Cyclophosphamide as a potent inhibitor of tumor thioredoxin reductase in vivo. Toxicol Appl Pharmacol 2007;218(1):88-95.

(191) Wang Y, Zhang H, Holmgren A, Tian W, Zhong L. Inhibitory effect of green tea extract and (-)-epigallocatechin-3-gallate on mammalian thioredoxin reductase and HeLa cell viability. Oncol Rep 2008;20(6):1479-1487.

(192) Lindner DJ, Hofmann ER, Karra S, Kalvakolanu DV. The interferon-beta and tamoxifen combination induces apoptosis using thioredoxin reductase. Biochim Biophys Acta 2000;1496(2-3):196-206.

(193) Liu Y, Min W. Thioredoxin promotes ASK1 ubiquitination and degradation to inhibit ASK1-mediated apoptosis in a redox activity-independent manner. Circ Res 2002;90(12):1259-1266.

(194) Kondo N, Ishii Y, Kwon YW et al. Lipid raft-mediated uptake of cysteinemodified thioredoxin-1: apoptosis enhancement by inhibiting the endogenous thioredoxin-1. Antioxid Redox Signal 2007;9(9):1439-1448. 
(195) Liu H, Nishitoh H, Ichijo H, Kyriakis JM. Activation of apoptosis signalregulating kinase 1 (ASK1) by tumor necrosis factor receptor-associated factor 2 requires prior dissociation of the ASK1 inhibitor thioredoxin. Mol Cell Biol 2000;20(6):2198-2208.

(196) Kwon SJ, Song JJ, Lee YJ. Signal pathway of hypoxia-inducible factor-1alpha phosphorylation and its interaction with von Hippel-Lindau tumor suppressor protein during ischemia in MiaPaCa-2 pancreatic cancer cells. Clin Cancer Res 2005;11(21):7607-7613.

(197) Hattori K, Naguro I, Runchel C, Ichijo H. The roles of ASK family proteins in stress responses and diseases. Cell Commun Signal 2009;7:9.

(198) Junn E, Han SH, Im JY et al. Vitamin D3 up-regulated protein 1 mediates oxidative stress via suppressing the thioredoxin function. J Immunol 2000;164(12):6287-6295.

(199) Nadeau PJ, Charette SJ, Toledano MB, Landry J. Disulfide Bond-mediated Multimerization of Ask1 and Its Reduction by Thioredoxin-1 Regulate H2O2induced JNK Activation and Apoptosis. Mol Biol Cell 2007.

(200) Huang YL, Chuang CY, Sung FC, Chen CY. Thioredoxin overexpression modulates remodeling factors in stress responses to cigarette smoke. $J$ Toxicol Environ Health A 2008;71(22):1490-1498.

(201) Akterin S, Cowburn RF, Miranda-Vizuete A et al. Involvement of glutaredoxin-1 and thioredoxin-1 in beta-amyloid toxicity and Alzheimer's disease. Cell Death Differ 2006;13(9):1454-1465.

(202) Lim PL, Liu J, Go ML, Boelsterli UA. The mitochondrial superoxide/thioredoxin2/Ask1 signaling pathway is critically involved in troglitazone-induced cell injury to human hepatocytes. Toxicol Sci 2008;101(2):341-349.

(203) Zhang Y, Shen X. Heat shock protein 27 protects L929 cells from cisplatininduced apoptosis by enhancing Akt activation and abating suppression of thioredoxin reductase activity. Clin Cancer Res 2007;13(10):2855-2864.

(204) Chen CL, Lin CF, Chang WT, Huang WC, Teng CF, Lin YS. Ceramide induces p38 MAPK and JNK activation through a mechanism involving a thioredoxininteracting protein-mediated pathway. Blood 2008;111(8):4365-4374.

(205) Csiki I, Yanagisawa K, Haruki N et al. Thioredoxin-1 modulates transcription of cyclooxygenase-2 via hypoxia-inducible factor-1alpha in non-small cell lung cancer. Cancer Res 2006;66(1):143-150. 
(206) Kim WJ, Cho H, Lee SW, Kim YJ, Kim KW. Antisense-thioredoxin inhibits angiogenesis via $\mathrm{pVHL}-$ mediated hypoxia-inducible factor-1alpha degradation. Int J Oncol 2005;26(4):1049-1052.

(207) Zhou J, Damdimopoulos AE, Spyrou G, Brune B. Thioredoxin 1 and thioredoxin 2 have opposed regulatory functions on hypoxia-inducible factor-1 alpha. $J$ Biol Chem 2007;282(10):7482-7490.

(208) Shih AY, Li P, Murphy TH. A small-molecule-inducible Nrf2-mediated antioxidant response provides effective prophylaxis against cerebral ischemia in vivo. J Neurosci 2005;25(44):10321-10335.

(209) Jia L, Xu M, Zhen $\mathrm{W}$ et al. Novel anti-oxidative role of calreticulin in protecting A549 human type II alveolar epithelial cells against hypoxic injury. Am J Physiol Cell Physiol 2008;294(1):C47-C55.

(210) Stacy DR, Ely K, Massion PP et al. Increased expression of nuclear factor E2 p45-related factor 2 (NRF2) in head and neck squamous cell carcinomas. Head Neck 2006;28(9):813-818.

(211) Sakurai A, Nishimoto M, Himeno S et al. Transcriptional regulation of thioredoxin reductase 1 expression by cadmium in vascular endothelial cells: role of NF-E2-related factor-2. J Cell Physiol 2005;203(3):529-537.

(212) Hansen JM, Watson WH, Jones DP. Compartmentation of Nrf-2 redox control: regulation of cytoplasmic activation by glutathione and DNA binding by thioredoxin-1. Toxicol Sci 2004;82(1):308-317.

(213) Kim SK, Yang JW, Kim MR et al. Increased expression of Nrf2/ARE-dependent anti-oxidant proteins in tamoxifen-resistant breast cancer cells. Free Radic Biol Med 2008;45(4):537-546.

(214) Matsuura T, Harrison RA, Westwell AD, Nakamura H, Martynyuk AE, Sumners C. Basal and angiotensin II-inhibited neuronal delayed-rectifier $\mathrm{K}+$ current are regulated by thioredoxin. Am J Physiol Cell Physiol 2007;293(1):C211-C217.

(215) Tamaki H, Nakamura H, Nishio A et al. Human thioredoxin-1 ameliorates experimental murine colitis in association with suppressed macrophage inhibitory factor production. Gastroenterology 2006;131(4):1110-1121.

(216) Fukumoto A, Tomoda K, Kubota M, Kato JY, Yoneda-Kato N. Small Jab1containing subcomplex is regulated in an anchorage- and cell cycle-dependent manner, which is abrogated by ras transformation. FEBS Lett 2005;579(5):10471054. 
(217) Kim KY, Shin SM, Kim JK, Paik SG, Yang Y, Choi I. Heat shock factor regulates VDUP1 gene expression. Biochem Biophys Res Commun 2004;315(2):369-375.

(218) Kim SY, Suh HW, Chung JW, Yoon SR, Choi I. Diverse functions of VDUP1 in cell proliferation, differentiation, and diseases. Cell Mol Immunol 2007;4(5):345351.

(219) Patwari P, Higgins LJ, Chutkow WA, Yoshioka J, Lee RT. The interaction of thioredoxin with Txnip. Evidence for formation of a mixed disulfide by disulfide exchange. J Biol Chem 2006;281(31):21884-21891.

(220) Deroo BJ, Hewitt SC, Peddada SD, Korach KS. Estradiol regulates the thioredoxin antioxidant system in the mouse uterus. Endocrinology 2004;145(12):5485-5492.

(221) Takahashi Y, Masuda H, Ishii Y, Nishida Y, Kobayashi M, Asai S. Decreased expression of thioredoxin interacting protein mRNA in inflamed colonic mucosa in patients with ulcerative colitis. Oncol Rep 2007;18(3):531-535.

(222) Sheth SS, Castellani LW, Chari S et al. Thioredoxin-interacting protein deficiency disrupts the fasting-feeding metabolic transition. J Lipid Res 2005;46(1):123-134.

(223) Shalev A. Lack of TXNIP protects beta-cells against glucotoxicity. Biochem Soc Trans 2008;36(Pt 5):963-965.

(224) Qi W, Chen X, Gilbert RE et al. High Glucose-Induced Thioredoxin-Interacting Protein in Renal Proximal Tubule Cells Is Independent of Transforming Growth Factor-\{beta\}1. Am J Pathol 2007.

(225) Turturro F, Von BG, Friday E. Hyperglycemia-induced thioredoxin-interacting protein expression differs in breast cancer-derived cells and regulates paclitaxel IC50. Clin Cancer Res 2007;13(12):3724-3730.

(226) Turturro F, Friday E, Welbourne T. Hyperglycemia regulates thioredoxin-ROS activity through induction of thioredoxin-interacting protein (TXNIP) in metastatic breast cancer-derived cells MDA-MB-231. BMC Cancer 2007;7:96.

(227) van Greevenbroek MM, Vermeulen VM, Feskens EJ et al. Genetic variation in thioredoxin interacting protein (TXNIP) is associated with hypertriglyceridaemia and blood pressure in diabetes mellitus. Diabet Med 2007;24(5):498-504.

(228) Minn AH, Pise-Masison CA, Radonovich M et al. Gene expression profiling in INS-1 cells overexpressing thioredoxin-interacting protein. Biochem Biophys Res Commun 2005;336(3):770-778. 
(229) Nadeau PJ, Charette SJ, Toledano MB, Landry J. Disulfide Bond-mediated multimerization of Ask1 and its reduction by thioredoxin-1 regulate $\mathrm{H}(2) \mathrm{O}(2)-$ induced c-Jun NH(2)-terminal kinase activation and apoptosis. Mol Biol Cell 2007;18(10):3903-3913.

(230) Haendeler J, Tischler V, Hoffmann J, Zeiher AM, Dimmeler S. Low doses of reactive oxygen species protect endothelial cells from apoptosis by increasing thioredoxin-1 expression. FEBS Lett 2004;577(3):427-433.

(231) Satoh M, Matter CM, Ogita $\mathrm{H}$ et al. Inhibition of apoptosis-regulated signaling kinase-1 and prevention of congestive heart failure by estrogen. Circulation 2007;115(25):3197-3204.

(232) Husbeck B, Powis G. The redox protein thioredoxin-1 regulates the constitutive and inducible expression of the estrogen metabolizing cytochromes P450 1B1 and 1A1 in MCF-7 human breast cancer cells. Carcinogenesis 2002;23(10):16251630.

(233) Ivan D, Diwan AH, Esteva FJ, Prieto VG. Expression of cell cycle inhibitor p27Kip1 and its inactivator Jab1 in melanocytic lesions. Mod Pathol 2004;17(7):811-818.

(234) Sheaff RJ, Groudine M, Gordon M, Roberts JM, Clurman BE. Cyclin E-CDK2 is a regulator of p27Kip1. Genes Dev 1997;11(11):1464-1478.

(235) Alkarain A, Jordan R, Slingerland J. p27 deregulation in breast cancer: prognostic significance and implications for therapy. J Mammary Gland Biol Neoplasia 2004;9(1):67-80.

(236) Ciarallo S, Subramaniam V, Hung W et al. Altered p27(Kip1) phosphorylation, localization, and function in human epithelial cells resistant to transforming growth factor beta-mediated G(1) arrest. Mol Cell Biol 2002;22(9):2993-3002.

(237) Alkarain A, Slingerland J. Deregulation of p27 by oncogenic signaling and its prognostic significance in breast cancer. Breast Cancer Res 2004;6(1):13-21.

(238) Chu I, Sun J, Arnaout A et al. p27 phosphorylation by Src regulates inhibition of cyclin E-Cdk2. Cell 2007;128(2):281-294.

(239) Sandhu C, Slingerland J. Deregulation of the cell cycle in cancer. Cancer Detect Prev 2000;24(2):107-118.

(240) Liang J, Slingerland JM. Multiple roles of the PI3K/PKB (Akt) pathway in cell cycle progression. Cell Cycle 2003;2(4):339-345. 
(241) Hong F, Larrea MD, Doughty C, Kwiatkowski DJ, Squillace R, Slingerland JM. mTOR-raptor binds and activates SGK1 to regulate 27 phosphorylation. $\mathrm{Mol}$ Cell 2008;30(6):701-711.

(242) Liang J, Shao SH, Xu ZX et al. The energy sensing LKB1-AMPK pathway regulates p27(kip1) phosphorylation mediating the decision to enter autophagy or apoptosis. Nat Cell Biol 2007;9(2):218-224.

(243) Planas-Silva MD, Hamilton KN. Targeting c-Src kinase enhances tamoxifen's inhibitory effect on cell growth by modulating expression of cell cycle and survival proteins. Cancer Chemother Pharmacol 2007;60(4):535-543.

(244) Slingerland J, Pagano M. Regulation of the cdk inhibitor p27 and its deregulation in cancer. J Cell Physiol 2000;183(1):10-17.

(245) Catzavelos C, Tsao MS, DeBoer G, Bhattacharya N, Shepherd FA, Slingerland JM. Reduced expression of the cell cycle inhibitor p27Kip1 in non-small cell lung carcinoma: a prognostic factor independent of Ras. Cancer Res 1999;59(3):684688.

(246) Tan P, Cady B, Wanner M et al. The cell cycle inhibitor p27 is an independent prognostic marker in small $(\mathrm{T} 1 \mathrm{a}, \mathrm{b})$ invasive breast carcinomas. Cancer Res 1997;57(7):1259-1263.

(247) Cariou S, Catzavelos C, Slingerland JM. Prognostic implications of expression of the cell cycle inhibitor protein p27Kip1. Breast Cancer Res Treat 1998;52(13):29-41.

(248) Jordan RC, Bradley G, Slingerland J. Reduced levels of the cell-cycle inhibitor p27Kip1 in epithelial dysplasia and carcinoma of the oral cavity. Am J Pathol 1998;152(2):585-590.

(249) Connor MK, Kotchetkov R, Cariou S et al. CRM1/Ran-mediated nuclear export of p27(Kip1) involves a nuclear export signal and links p27 export and proteolysis. Mol Biol Cell 2003;14(1):201-213.

(250) Tomoda K, Kubota Y, Kato J. Degradation of the cyclin-dependent-kinase inhibitor p27Kip1 is instigated by Jab1. Nature 1999;398(6723):160-165.

(251) Chu IM, Hengst L, Slingerland JM. The Cdk inhibitor p27 in human cancer: prognostic potential and relevance to anticancer therapy. Nat Rev Cancer 2008;8(4):253-267. 
(252) Sui L, Dong Y, Ohno M et al. Jab1 expression is associated with inverse expression of p27(kip1) and poor prognosis in epithelial ovarian tumors. Clin Cancer Res 2001;7(12):4130-4135.

(253) Nguyen MT, Beck J, Lue $\mathrm{H}$ et al. A 16-residue peptide fragment of macrophage migration inhibitory factor, MIF-(50-65), exhibits redox activity and has MIF-like biological functions. $J$ Biol Chem 2003;278(36):33654-33671.

(254) Chamovitz DA, Segal D. JAB1/CSN5 and the COP9 signalosome. A complex situation. EMBO Rep 2001;2(2):96-101.

(255) Wang H, Sun X, Luo Y, Lin Z, Wu J. Adapter protein NRBP associates with Jab1 and negatively regulates AP-1 activity. FEBS Lett 2006;580(25):6015-6021.

(256) Esteva FJ, Sahin AA, Rassidakis GZ et al. Jun activation domain binding protein 1 expression is associated with low p27(Kip1)levels in node-negative breast cancer. Clin Cancer Res 2003;9(15):5652-5659.

(257) Esteva FJ, Sahin AA, Rassidakis GZ et al. Jun activation domain binding protein 1 expression is associated with low p27(Kip1)levels in node-negative breast cancer. Clin Cancer Res 2003;9(15):5652-5659.

(258) Lu C, Li Y, Zhao Y et al. Intracrine hepatopoietin potentiates AP-1 activity through JAB1 independent of MAPK pathway. FASEB J 2002;16(1):90-92.

(259) Kouvaraki MA, Rassidakis GZ, Tian L, Kumar R, Kittas C, Claret FX. Jun activation domain-binding protein 1 expression in breast cancer inversely correlates with the cell cycle inhibitor p27(Kip1). Cancer Res 2003;63(11):29772981.

(260) Kouvaraki MA, Rassidakis GZ, Tian L, Kumar R, Kittas C, Claret FX. Jun activation domain-binding protein 1 expression in breast cancer inversely correlates with the cell cycle inhibitor p27(Kip1). Cancer Res 2003;63(11):29772981.

(261) Emberley ED, Alowami S, Snell L, Murphy LC, Watson PH. S100A7 (psoriasin) expression is associated with aggressive features and alteration of Jab1 in ductal carcinoma in situ of the breast. Breast Cancer Res 2004;6(4):R308-R315.

(262) Tsuchida R, Miyauchi J, Shen L et al. Expression of cyclin-dependent kinase inhibitor $\mathrm{p} 27 / \mathrm{Kip} 1$ and AP-1 coactivator $\mathrm{p} 38 / \mathrm{Jab} 1$ correlates with differentiation of embryonal rhabdomyosarcoma. Jpn J Cancer Res 2002;93(9):1000-1006.

(263) Bonner SE, Morris DG, Korbonits M et al. Cell cycle dysregulation in breast cancer - the roles of Jab1 and Archipelago. Endocrine Abstracts 9, P89. 2005. 
(264) Denicourt C, Saenz CC, Datnow B, Cui XS, Dowdy SF. Relocalized p27Kip1 tumor suppressor functions as a cytoplasmic metastatic oncogene in melanoma. Cancer Res 2007;67(19):9238-9243.

(265) Callige M, Kieffer I, Richard-Foy H. CSN5/Jab1 is involved in ligand-dependent degradation of estrogen receptor $\{$ alpha\} by the proteasome. Mol Cell Biol 2005;25(11):4349-4358.

(266) Fukumoto A, Tomoda K, Kubota M, Kato JY, Yoneda-Kato N. Small Jab1containing subcomplex is regulated in an anchorage- and cell cycle-dependent manner, which is abrogated by ras transformation. FEBS Lett 2005;579(5):10471054.

(267) Fruehauf JP, Meyskens FL, Jr. Reactive oxygen species: a breath of life or death? Clin Cancer Res 2007;13(3):789-794.

(268) Damdimopoulos AE, Miranda-Vizuete A, Treuter E, Gustafsson JA, Spyrou G. An alternative splicing variant of the selenoprotein thioredoxin reductase is a modulator of estrogen signaling. J Biol Chem 2004;279(37):38721-38729.

(269) Jonsson-Videsater K, Bjorkhem-Bergman L, Hossain A et al. Selenite-induced apoptosis in doxorubicin-resistant cells and effects on the thioredoxin system. Biochem Pharmacol 2004;67(3):513-522.

(270) Iwao-Koizumi K, Matoba R, Ueno $\mathrm{N}$ et al. Prediction of docetaxel response in human breast cancer by gene expression profiling. J Clin Oncol 2005;23(3):422431.

(271) Azuma K, Komohara Y, Sasada T et al. Excision repair cross-complementation group 1 predicts progression-free and overall survival in non-small cell lung cancer patients treated with platinum-based chemotherapy. Cancer $S c i$ 2007;98(9):1336-1343.

(272) Kim SJ, Miyoshi Y, Taguchi T et al. High thioredoxin expression is associated with resistance to docetaxel in primary breast cancer. Clin Cancer Res 2005;11(23):8425-8430.

(273) Chen X, Li Y, Wei K et al. The potentiation role of hepatopoietin on activator protein-1 is dependent on its sulfhydryl oxidase activity. J Biol Chem 2003;278(49):49022-49030.

(274) Liang J, Zubovitz J, Petrocelli T et al. PKB/Akt phosphorylates p27, impairs nuclear import of p27 and opposes p27-mediated G1 arrest. Nat Med 2002;8(10):1153-1160. 
(275) Weng LP, Brown JL, Eng C. PTEN coordinates G(1) arrest by down-regulating cyclin D1 via its protein phosphatase activity and up-regulating p27 via its lipid phosphatase activity in a breast cancer model. Hum Mol Genet 2001;10(6):599604.

(276) Lee H, Xie L, Luo Y et al. Identification of phosphocaveolin-1 as a novel protein tyrosine phosphatase 1B substrate. Biochemistry 2006;45(1):234-240.

(277) Liang F, Lee SY, Liang J, Lawrence DS, Zhang ZY. The role of protein-tyrosine phosphatase 1B in integrin signaling. J Biol Chem 2005;280(26):24857-24863.

(278) Roskoski R, Jr. Src kinase regulation by phosphorylation and dephosphorylation. Biochem Biophys Res Commun 2005;331(1):1-14.

(279) Bartholomew PJ, Jones CW, Benware A, Chernoff J, LaFlamme SE. Regulation of the catalytic activity of PTP1B: roles for cell adhesion, tyrosine residue 66, and proline residues 309 and 310. Exp Cell Res 2005;311(2):294-306.

(280) Sternfeld L, Krause E, Schmid A et al. Tyrosine phosphatase PTP1B interacts with TRPV6 in vivo and plays a role in TRPV6-mediated calcium influx in HEK293 cells. Cell Signal 2005;17(8):951-960.

(281) Lee SR, Yang KS, Kwon J, Lee C, Jeong W, Rhee SG. Reversible inactivation of the tumor suppressor PTEN by H2O2. J Biol Chem 2002;277(23):20336-20342.

(282) Sohn J, Rudolph J. Catalytic and chemical competence of regulation of cdc25 phosphatase by oxidation/reduction. Biochemistry 2003;42(34):10060-10070.

(283) Rudolph J. Redox regulation of the Cdc25 phosphatases. Antioxid Redox Signal 2005;7(5-6):761-767.

(284) van den Berk LC, Landi E, Harmsen E, Dente L, Hendriks WJ. Redox-regulated affinity of the third PDZ domain in the phosphotyrosine phosphatase PTP-BL for cysteine-containing target peptides. FEBS J 2005;272(13):3306-3316.

(285) Mueller AS, Klomann SD, Wolf NM et al. Redox regulation of protein tyrosine phosphatase $1 \mathrm{~B}$ by manipulation of dietary selenium affects the triglyceride concentration in rat liver. $J$ Nutr 2008;138(12):2328-2336.

(286) Bjornstrom L, Sjoberg M. Mechanisms of Estrogen Receptor Signaling: Convergence of Genomic and Nongenomic Actions on Target Genes. Mol Endocrinol 2005; 19(4):833-842.

(287) Osborne CK, Schiff R. Mechanisms of Endocrine Resistance in Breast Cancer. Annu Rev Med 2011; 62:14.1-14.15. 


\section{Figures}

Figure 1-LR

Estrogen actions in breast cancer. Most well characterized is the genomic action of estrogen binding to the ER, and this complex binding to EREs in the DNA. Non-genomic actions include activation of the PI3K and MAPK pathways. More recently, cellsignaling activation through ROS formation has been explored. ${ }^{23,28,29,126,286,287}$

Figure 2-LR 
Sources of oxidants and actions of antioxidants. Schematic of major sources of ROS and antioxidants that counteract the oxidative effects of this ROS.

Figure 3-LR

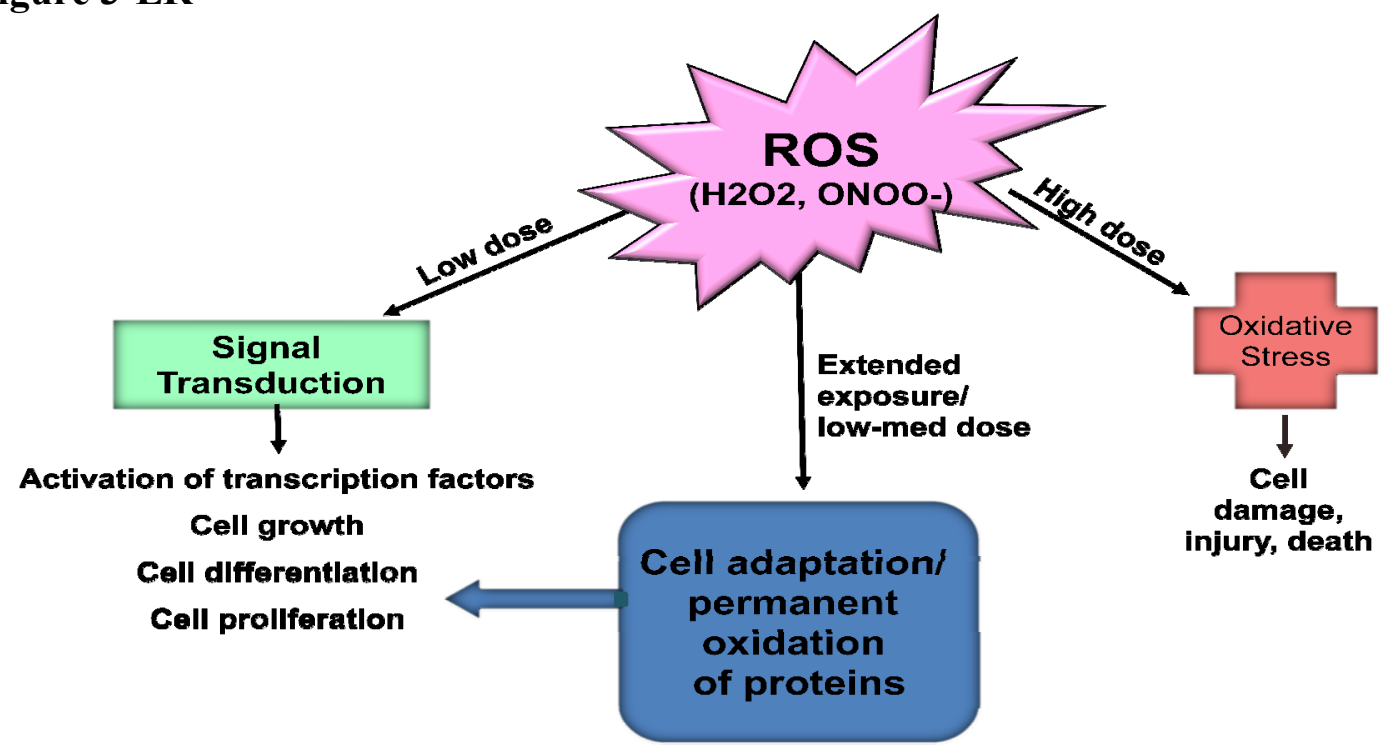

Cellular dose/response to oxidants. While high doses of ROS can lead to apoptosis, and low levels can lead to cell growth, chronic exposure to antiestrogens can lead to an adaptation of the cell and subsequent $\mathrm{AE}$ resistance.

Figure 4-LR

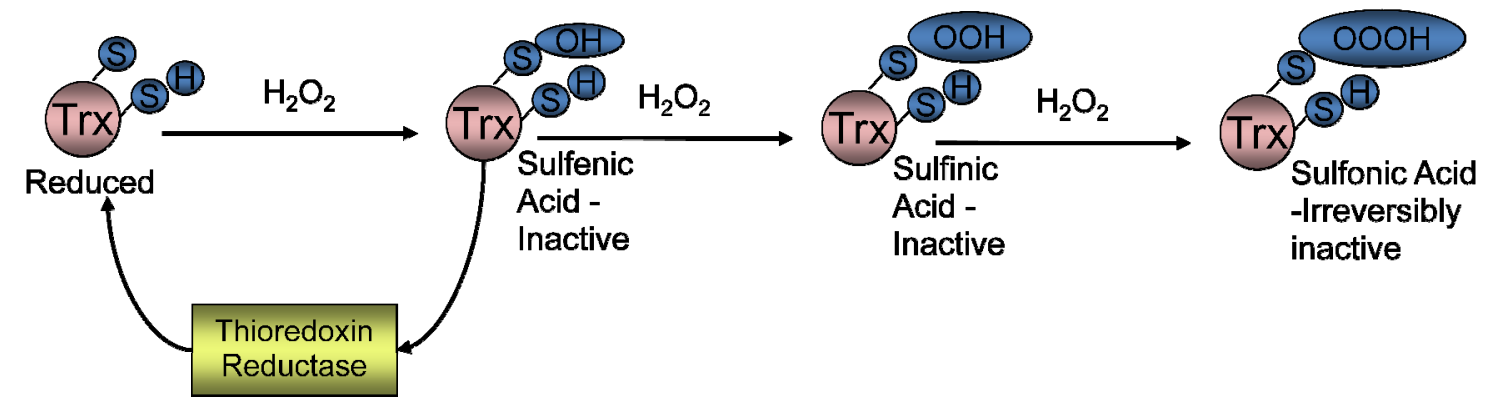

Thioredoxin oxidation and reduction. After oxidation, thioredoxin becomes more susceptible to overoxidation by $\mathrm{H}_{2} \mathrm{O}_{2}$ until it become irreversibly inactive. The increase in ROS from tamoxifen treatment can lead to the oxidation and overoxidation of thioredoxin, and perhaps plays a role in antiestrogen resistance. 
Figure 5-LR

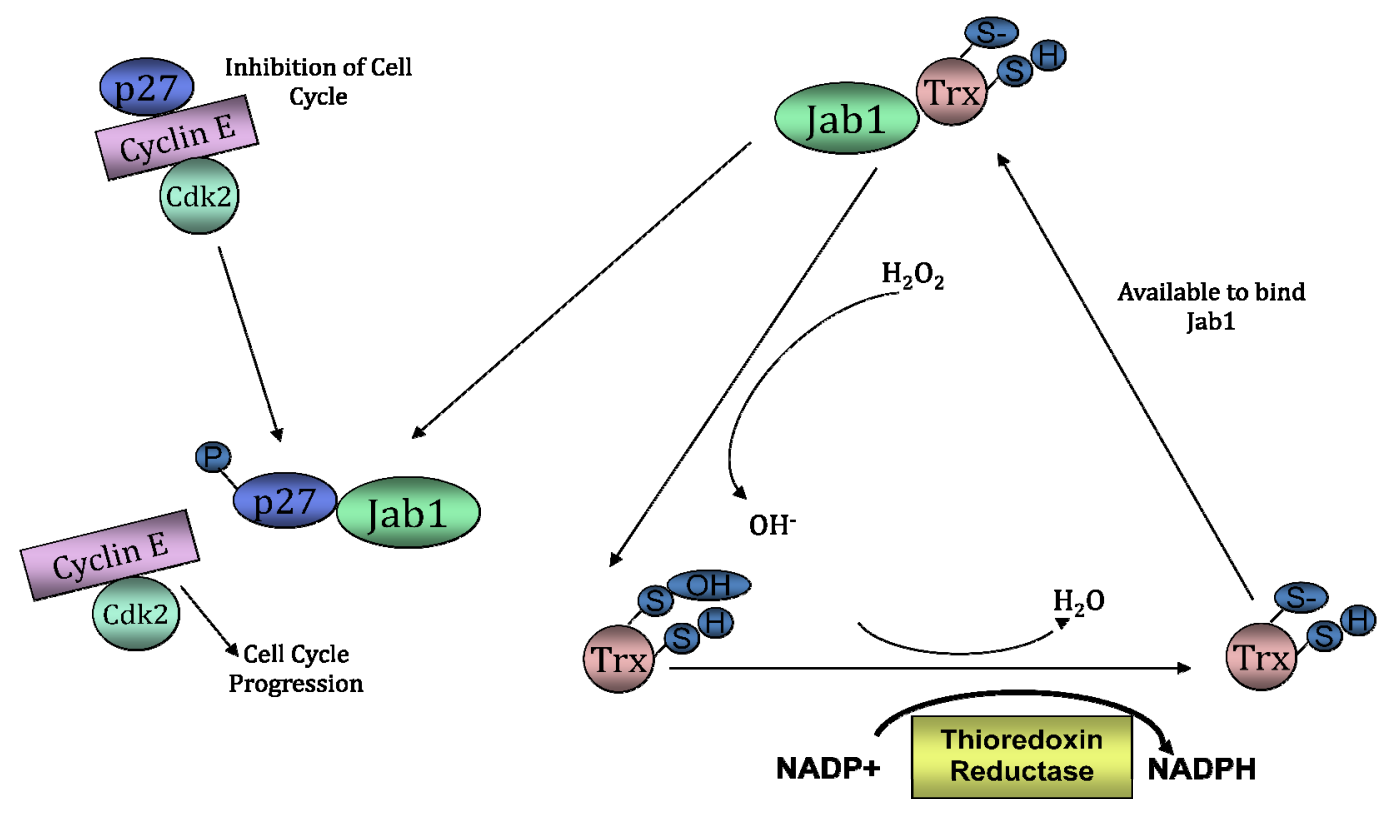

Proposed role of thioredoxin in AE resistance. We propose a Trx/Jab1 interaction that mimics the Trx/Ask1 interaction. Oxidation (inactivation) of thioredoxin from AEgenerated ROS leads to a release of Jab1. Jab1 is then free to bind to p27, carrying it out of the nucleus. With p27 gone, the Cyclin E/cdk2 complex is free to forward cell cycle progression.

\title{
III INCREASING THIOREDOXIN REDUCTASE EXPRESSION OR REDUCING JAB1 EXPRESSION REDUCES CELL PROLIFERATION IN TAMOXIFEN-TREATED LCC2 CELLS
}

\begin{abstract}
Antiestrogen resistance is a major problem in breast cancer treatment. While the reactive oxygen species that are produced by selective estrogen receptor modulators such as tamoxifen are not thought to play a major role in treatment, it may have a role in the
\end{abstract}


development of resistance. For this study we looked at the role of thioredoxin and its ability to alter the oxidative state of tamoxifen-resistant (LCC2) cells. We also explored the Jab1/thioredoxin pathway as a way thioredoxin may alter the effects of resistance on the cell cycle inhibitor $\mathrm{p} 27$. We show that overexpressing thioredoxin reductase or underexpressing Jab1 inhibits growth of tamoxifen-resistant cells upon tamoxifen treatment. We also show that $\mathrm{p} 27$ phosphorylation is altered when thioredoxin reductase or Jab1 levels are altered. This data implies a role for antioxidants in reversing tamoxifen resistance. Through altering p27 phosphorylation, changing the redox nature of tamoxifen resistant cells may not only reverse but also may prevent tamoxifen resistance.

\section{Introduction}

A major problem with the use of antiestrogens (AE) is the prevalence of resistance, either at the outset of treatment or after continued use, and underlying mechanisms of this resistance remain unclear. Selective estrogen receptor modulator (SERM) antiestrogens are capable of producing ROS through their metabolic activation. It is possible that SERMs may play a role in estrogen receptor (ER) positive breast cancer growth arrest by a mechanism involving ROS accumulation. Breast cancer receiving long-term antiestrogen treatment appears to adapt to this increased, persistent level of ROS, leading to the disruption of reversible redox signaling that involves redox-sensitive phosphatases and kinases, such as ERK and Akt. This has downstream consequences for apoptosis, cell cycle progression, and cell metabolism. ${ }^{1,2}$ 
The inactivation of the thioredoxin antioxidant family can disrupt reversible redox signaling pathways and cause the cell to become unresponsive to certain stimuli, or lead to the continued activation of cell signaling pathways such as MAPKs, and further the activation of transcription factors and subsequent cell proliferation. ${ }^{3}$ It may also play a role in making Jab1 protein available to move the cell-cycle inhibitor p27 from the nucleus and freeing the cyclin E / cdk2 complex to forward cell progression. Thioredoxin (Trx) has been found to compete with p27 for binding with Jab1 in HEK293T (human embryonic kidney) cells, and, through this, negatively regulate p27 degradation. ${ }^{4}$

There is very little research in the area of reactive oxygen species as a mechanism for tamoxifen resistance. One study has looked at glutathione as an antioxidant that can affect the oxidation of the MKP3 phosphatase. There appear to be no studies exploring the role of thioredoxin as an inhibitor of antiestrogen resistance. There also are no studies regarding the role of Jab1 in $\mathrm{AE}$ resistance, however, it has been shown that there needs to be a certain level of p27 in breast cancer cells for the cells to respond to tamoxifen, and that increasing MAPK pathway activation increases p27 phosphorylation and reduces levels of p27, leading to tamoxifen resistance. ${ }^{5}$

Thioredoxin and thioredoxin reductase (TrxR) are considered prime targets for resistance to chemotherapeutic drugs that utilize high levels of ROS to kill breast cancer cells, such as docetaxel, a potent anti-cancer drug. ${ }^{6}$ However, with drugs that do not utilize ROS as their main mechanism, such as tamoxifen, chronic exposure to the lower levels of ROS produced have not been explored as part of the mechanisms of action. With the exception 
of the previously mentioned MKP3 study, the alteration of cellular ROS has not been explored as a pathway to reversing/preventing tamoxifen resistance.

We suggest that chronic tamoxifen usage increases ROS and inactivates the antioxidant Trx family through oxidation. This oxidation can affect several signaling pathways and lead to cell cycle progression in the presence of tamoxifen treatment. In this study we overexpressed thioredoxin reductase and underexpressed Jab1 proteins to explore the role of each in tamoxifen resistance. Our data indicate there is a role for TrxR overexpression or Jablunderexpression in reversing or preventing tamoxifen resistance through alteration of p27 phosphorylation.

\section{Materials and methods}

Cell lines, cultures, and treatments: The tamoxifen-resistant/fulvestrant-sensitive human breast adenocarcinoma MCF-7-variant LCC2 cell line was propagated in phenol red-free Dulbecco's Modified Eagle Medium F12 (DMEM/F12) with L-Glutamine and 15mM HEPES (Invitrogen, Grand Island, NY; Mediatech, Manassas, VA) containing 5\% (v/v) fetal bovine serum (Invitrogen), $100 \mathrm{u} / \mathrm{mL}$ penicillin $\mathrm{G}$ sodium, and $100 \mathrm{ug} / \mathrm{mL}$ streptomycin sulfate (Invitrogen) at $37{ }^{\circ} \mathrm{C}$ in $5 \% \mathrm{CO}_{2}$ atmosphere. For experimental purposes, cells were seeded in 5\% FBS DMEM/F12 medium and allowed to adhere overnight. Culture medium was replaced with DMEM/F12 with 5\% charcoal/dextrantreated FBS (Invitrogen), and allowed to grow for $48 \mathrm{~h}$, followed by treatments $(0.1 \%$ DMSO, $1 \mu \mathrm{M}$ tamoxifen, $1 \mu \mathrm{M}$ fulvestrant [Sigma, St. Louis, MO]) as described in the figure legends. For cells with erucin treatment, $10 \mu \mathrm{M}$ erucin (LKT Laboratories, St. 
Paul, MN) was added with the DMEM/F12 with charcoal/dextran-treated FBS for the initial 48 hours in order to overexpress thioredoxin reductase 1 (TrxR1). Media was then removed from erucin-treated cells, fresh media was added, and treatments administered.

Transfection procedures: pRS shRNA vector without shRNA cassette insert, pRS HuSH 29mer shRNA constructs against COPS5 (Jab1), and pCMV6-XL4 carrying the fulllength human TrxR2 cDNA (OriGene Technologies, Rockville, MD, USA) were purified using MAX Efficiency ${ }^{\circledR}$ DH5 $\alpha^{\mathrm{TM}}$ Competent Cells (Invitrogen) and plasmid was extracted using phenol extraction and ethanol precipitation. For transfection, cells were seeded in 6-well plates at 70\%. After overnight incubation, transfection was performed using Fugene (1:3) and left to incubate overnight in Optimem (Invitrogen) or DMEM/F12 with no serum or antibiotics. The next day media was changed to growth media and cells were allowed to recuperate overnight. Cells were seeded the next day. HuSH 29-mer noneffective (scrambled) pRS vector (Origene) was tested and showed similar actions to the empty plasmid vector (data not shown).

Antibodies: All antibodies used were purchased from Santa Cruz (Santa Cruz, CA), except the following: GAPDH (Sigma), $\beta$-actin (Sigma), and p27 phosphorylated at T157 (Abcam, Cambridge, MA).

Soft agar colony formation assay: Cells were seeded at a concentration of 500 cells/well in $0.25 \%$ agar on a $0.5 \%$ agar base using $5 \%$ FBS in 48 -well plates. Cells were fed 2 
times per week with treatments as described in figure legends, and colonies were counted on days 16 and 18. Each assay was repeated three times with triplicate treatments.

BrdU cell proliferation assay: Cells were grown ( 2500 cells/well) in 96-well plates in DMEM/F12 with 5\% charcoal/dextran-treated FBS for $48 \mathrm{~h}$ (certain wells also including $10 \mu \mathrm{M}$ erucin), followed by treatments in DMEM/F12 with charcoal/dextran-treated FBS as described in the figure legends for $48 \mathrm{~h}$. A colorimetric BrdU cell proliferation assay was performed according to the manufacturer's instructions (Roche, Indianapolis, IN). After incubation with treatments, cells were labeled for 24 hours at $37^{\circ} \mathrm{C}$ in $5 \% \mathrm{CO}$. After 30 minutes of fixation and denaturing (FixDenat), cells were incubated with antiBrdU-peroxidase antibody (1:1000) for 90 minutes. Cells were washed three times with PBS, and the final substrate was added. Sample measurements were taken with Synergy HT (BioTek, Winooski, VT) plate reader at $370 \mathrm{~nm}$ (reference $\lambda$ at $492 \mathrm{~nm}$ ) at time points from 5-30 minutes at 5-minute intervals.

Redox Western: The procedure for redox western for thioredoxin has been described in detail. $^{7}$ Briefly, LCC2 cells were seeded at either 400,000 / well ( 6 well plate) or $1 \mathrm{x}$ $10^{6} /$ plate (100 mm plates). After overnight incubation, media with charcoal/dextran treated FBS was added to all cells, with $10 \mu \mathrm{M}$ erucin added to specified wells/plates. After 48 hours, cells were treated as noted for 30 minutes. After washing twice with cold PBS, cells were scraped into $1.5 \mathrm{~mL}$ tubes with G lysis buffer with $50 \mathrm{mM}$ iodoacetic acid. Samples were incubated for 30 minutes at $37^{\circ}$. Lysate was sonicated briefly, then centrifuged for 3 minutes at $2000 \mathrm{xg}$ at room temperature. Lysate was transferred to new 
tubes, and a BCA assay was performed to quantitate proteins. $50 \mu \mathrm{g}$ was loaded in a native gel $(15 \%)$ under non-reducing conditions and run for 90 minutes at $150 \mathrm{~V}$ in native running buffer. Proteins were transferred to PVDF (GE Healthcare), blocked with 5\% BSA, and incubated in anti-Trx antibody overnight. An SDS-PAGE (12\%) was also run with the same lysate for loading control GAPDH or B-actin. Blots were developed using either a film developer (Konica Minolta) or VersaDoc imaging system using QuantityOne software (BioRad).

Redox potential (Eh) of Trx1 was calculated using the Nernst equation through the use of the reduced and oxidized bands of thioredoxin. The equation $\mathrm{Eh}(\mathrm{mV}$, redox potential $)=$ Eo (midpoint potential $)+(\mathrm{RT} / \mathrm{nF}) \ln (\operatorname{Trx} 1 \mathrm{Ox} / \mathrm{Trx} 1 \mathrm{Red})$ was used, where Eo $=-240 \mathrm{mV}$ for $\operatorname{Trx} 1$ at $\mathrm{pH} 7.0$ and $25^{\circ} \mathrm{C}, 30=\ln$ and $\mathrm{RT} / \mathrm{nF}$. This equation was calculated previously by Go and Jones by using values [R, universal gas constant; $\mathrm{T}$, absolute temperature; $\mathrm{n}$, number of electrons; F, Faraday constant]). The ratio of oxidized and reduced Trx1 (Trx1 Ox/Trx1 Red) band intensities was taken for each sample and used to calculate $\ln (\operatorname{Trx} 10 x / \operatorname{Trx} 1 \mathrm{Red})$. Thus, the final equation (as calculated by Go and Jones, 2009) reduces to $\mathrm{Eh}, \operatorname{Trx} 1=-240 \mathrm{mV}+30 \times \ln ($ ratio of Trx1Ox and Trx1Red). Immunoblot: Cells were seeded in $100 \mathrm{~mm}$ plates at $1 \times 10^{6}$ cells in DMEM/F12 with 5\% charcoal/dextran-treated FBS and allowed to grow for 48 hours. Cells were then treated with DMSO and tamoxifen for 48 hrs. Cells were rinsed with cold PBS, lysed (20mM HEPES (pH 7.2), $50 \mathrm{mM} \mathrm{NaCl}, 0.5 \%$ Triton X-100, 0.1mM Na $3 \mathrm{VO}_{4}, 1 \mathrm{mM} \mathrm{NaF}, 1 \mathrm{x}$ complete protease inhibitor (Roche)), and proteins isolated. Quantification of proteins was performed using the Pierce BCA Protein Assay Kit (Pierce, Rockford, IL), and lysate 
was boiled for 5 minutes at $95-100^{\circ} \mathrm{C}$. Acrylamide gel (12\%) was loaded with $100 \mu \mathrm{g}$ protein and run for $2.5 \mathrm{~h}$ at 150 volts. Proteins were transferred to PVDF and blots were blocked with either $5 \%$ milk or blocking buffer for phosphorylated proteins (1\% milk, $1 \% \mathrm{BSA}, 50 \mathrm{mM} \mathrm{NaF}$ ) in TBS-T. Blots were then incubated with anti-p27, anti-p27 (T157), and anti-p27 (T187) (Santa Cruz, US) antibodies overnight. Secondary antibodies were added for one hour, and blots were imaged using either a film developer (Konica Minolta) or VersaDoc imaging system using QuantityOne software (BioRad).

Co-immunoprecipitation: Cells were seeded in $100 \mathrm{~mm}$ plates at $1 \times 10^{6}$ cells in DMEM/F12 with $5 \%$ charcoal/dextran-treated FBS and allowed to grow for $48 \mathrm{~h}$. Cells were then treated with DMSO and tamoxifen for $48 \mathrm{~h}$. Cells were rinsed with cold PBS, lysed (NP-40 buffer, 1mM NaF, 1x complete protease inhibitor (Roche)), and proteins isolated. Quantification of proteins was performed using the Pierce BCA kit. $1000 \mu \mathrm{g}$ lysate was precleared with $30 \mathrm{uL}$ Protein A Agarose (Invitrogen) for 30 minutes. Lysate was separated from agarose beads, and incubated overnight with appropriate antibody ( 2 $\mathrm{ug} / \mathrm{mL}$ ). Lysates were then incubated for 90 minutes with $50 \mathrm{uL}$ Agarose A slurry, centrifuged, then supernatant removed. Beads were washed 3 times, and then $60 \mathrm{uL} 2.5 \mathrm{x}$ loading buffer was added. Lysate was boiled for 10 minutes at $95-100^{\circ} \mathrm{C}, 30 \mathrm{uL}$ was loaded in each of 2 acrylamide gels (12 and 15\%), and run for $2.5 \mathrm{~h}$ at 150 volts. Proteins were transferred to PVDF and blots were blocked with 5\% milk in TBS-T or 5\% BSA in TBS-T (Trx). Blots were then incubated with anti-Jab1, anti-p27, or anti-Trx) antibodies overnight. After washing, secondary antibodies were added (Santa Cruz) for 1 hour. Images were captured using either Kodak Film or Versadoc digital imaging. 


\section{Results}

\section{Upregulation of TrxR through Erucin treatment decreases proliferation and}

\section{tumorigenicity of tamoxifen treated tamoxifen-resistant breast cancer cells}

If indeed thioredoxin oxidation is playing a role in tamoxifen resistance, we would expect an increase in thioredoxin reductase (and the subsequent reduction of oxidized thioredoxin) to decrease tamoxifen-resistant cell proliferation after tamoxifen treatment. We first wanted to check the validity of this hypothesis on tamoxifen-resistant cells, and performed a soft agar anchorage-independence assay. Anchorage-independence is a hallmark of tumor growth, so we used this assay to see if the overexpression of thioredoxin reductase 1 or 2 would create an atmosphere of tamoxifen sensitivity. We transfected LCC2 cells to overexpress TrxR2 or co-treated LCC2 cells with erucin to increase TrxR1. Cells were treated for over 2 weeks, and colonies counted on days 16 and 18. Figure 1 shows the outcome of this experiment as representative pictures (A, B, C) and graphic representation of colony counts (D, E, F). We found that the overexpression of TrxR1 and TrxR2 each significantly decreased the number of colonies that formed after tamoxifen treatments.

Jab1 aids in removing p27 from its inhibitory position in the nucleus. We would expect an underexpression of Jab1 would increase available p27 and lead to the inhibition of tumor growth in tamoxifen treated resistance cells. We found that indeed the underexpression of Jab1 through plasmid transfection also leads to significantly decreased colony formation. 
We also looked at the DNA synthesis (cell proliferation) of these cells through the use of the BrdU incorporation assay. After incubating our cells with media with charcoal/dextran treated FBS, we treated the cells as noted for another 48 hours. We then labeled the cells for 24 hours with BrdU, and performed the BrdU assay (Roche). The overexpression of TrxR2 (Figure 2A), treatment of cells with erucin (overexpression of TrxR1, Figure 2B), and the underexpression of Jab1 (Figure 2C) show significant ( $\mathrm{p}<$ 0.05) decreases in DNA synthesis in LCC2 cells.

\section{Upregulation of TrxR and TrxR2 through isothiocyanate treatment and plasmid overexpression increases Trx and Trx 2 expression in LCC2 cells}

It has been seen in HepG2 and undifferentiated Caco-2 cells that an increase in TrxR expression leads to an increase in expression of $\operatorname{Trx},{ }^{8}$ and the dietary isothiocyanates sulforaphane, erucin, and iberin have been found to induce thioredoxin reductase in MCF-7 cells. ${ }^{9}$ Our hypothesis is based on an overexpression of thioredoxin and/or thioredoxin 2, and so to confirm this increase in protein expression in tamoxifen-resistant LCC 2 cells and to look at the expression of Trx 2 after TrxR2 overexpression we performed a western blot. Figure 3A shows plasmid overexpression of TrxR2 leads to an increase in Trx2. Figure 3B shows the overexpression of thioredoxin reductase through the use of the isothiocyanate sulforaphane, and the subsequent increase in Trx.

It is not only necessary to have more thioredoxin, but to also have more reduced thioredoxin to understand the validity of our hypothesis. As such, we also explored if the overexpression of thioredoxin reductase 1 and 2 led to a decrease in oxidized thioredoxin. 


\section{Tamoxifen increases ROS in LCC2 cells, and leads to an increase in oxidized thioredoxin in MCF-7 cells}

Tamoxifen has been shown to increase ROS in cells as estrogen does. We have previously shown that estrogen increases the oxidation of thioredoxin in MCF-7 cells. We wanted to explore the effect of tamoxifen on thioredoxin oxidation in breast cancer cells. Figure 4A shows that overexpression of TrxR2 increases levels of reduced thioredoxin, as does erucin treatment (Figure 4B). These data show that the reduction of oxidized thioredoxin occurs with the overexpression of TrxR2.

Isothiocyanates are able to oxidize TrxR and glutathione reductase. ${ }^{10}$ Here we see that while the use of the isothiocyanate erucin increases levels of oxidized Trx, it also significantly increases the amount in reduced (and thus active) Trx (Figure 4B). Figure $4 \mathrm{C}$ shows the redox potential as computed using the Nernst equation as noted in the Materials and Methods section. While the use of isothiocyanates decreases the redox potential due to the ratio of oxidized to reduced thioredoxin, the goal of this experiment was to increase the amount of reduced thioredoxin available in the cell, and this was achieved with isothiocyanate use.

We hypothesize that the oxidation and subsequent inactivation of thioredoxin may lead to cell cycle signaling that promotes tamoxifen resistance. If thioredoxin is not reducing other proteins, these proteins may be "switched on" or "switched off" and can cause cell proliferation even when treated with tamoxifen. When thioredoxin is oxidized, it may not be able to bind to the Jab1 protein, as it has been shown to do. ${ }^{4}$ This would leave Jab1 
free to bind to bind to p27, and carry it out of the nucleus, inhibiting p27 from controlling cell growth.

\section{Increased TrxR 1 and 2 increases Jab1/Trx binding}

In a variety of cancer cells, Jab1 has been negatively associated with p27 expression. ${ }^{11}$

Jab1 has been implicated as a major cause of the translocation of p27 from the nucleus to

the cytoplasm. ${ }^{12}$ Jab1 is thought to play a role in accelerating p27 degradation through the ubiquitin/proteosome pathway. Alternatively, Trx has been found to compete with $\mathrm{p} 27$ for binding with Jab1 in HEK293T (human embryonic kidney) cells, and, through this, negatively regulate p27 degradation. ${ }^{4}$ Because of this finding, we wanted to explore the possibility that Trx may bind with Jab1 in breast cancer cells, and to see if altering Trx oxidative state would also alter Jab1/p27 binding. We performed a coimmunoprecipitation, pulling down the Jab1 protein and probing it for Trx and for p27. We treated LCC 2 cells as before, then incubated 1mg of protein with $2 \mu \mathrm{g} \mathrm{Jab} 1$ antibody overnight and followed the protocol as noted in Materials and Methods. Figures 5A and 5B show binding between Jab1 and Trx1, and figures 5C and 5D show binding between Jab1 and p27 after overexpression of TrxR 1 and 2. When cells are pretreated with isothiocyanates, an increase in binding of Jab1 and Trx occurs after treatment with tamoxifen.

We also looked at Jab1 binding with p27, as we would expect to see Jab1/p27 binding decrease as Jab1/Trx binding increases. While we saw a drop in Jab1/p27 binding with the use of isothiocyanates, we did not see a significant decrease in Jab1/p27 binding as 
we expected when tamoxifen treatment was added. Thus we do not feel the binding of p27 to Jab1 is competitive with binding of Trx to Jab1. This is the first time, however, that Trx binding to Jab1 is shown in breast cancer cells

\section{TrxR1 and 2 overexpression and Jab1 underexpression decrease p27 phosphorylation at T187. Increased TrxR 1 but not TrxR2 or decreased Jab1 decrease p27 phosphorylation at T157}

p27 is a known cdk2 inhibitor. When p27 is phosphorylated and disconnects from cdk2, cdk2 is free to phosphorylate retinoblastoma, which can then activate the E2F gene and lead to cell proliferation. ${ }^{13,14}$ We explored the phosphorylation of p27 at the T187 and T157 sites. The T187 site is phosphorylated by cdk2 once other sources ( $\mathrm{Src})$ phosphorylate p27 at T74 and T88. ${ }^{15}$ T77 and T88 phosphorylation weaken the p27/cdk2 bond, and encourage T187 phosphorylation. Once p27 is phosphorylated at these sites, it becomes unbound from $\mathrm{cdk} 2$, and can be ubiquinated and subsequently degraded by the $26 \mathrm{~S}$ proteosome. ${ }^{13,16}$ We hypothesize that it is at this point Jab1 can bind to $\mathrm{p} 27$ and aid in p27 degradation. We found that p27 is phosphorylated at 187 in LCC2 cells, but when TrxR 1 and 2 are overexpressed or Jab1 is underexpressed, T187 phosphorylation decreases. (Figures 6A and 6B)

The T157 phosphorylation site prohibits p27 translocation into the nucleus. As such, p27 is not available for cdk2/cyclin E binding, and cannot perform its inhibitory role. It also is available for and promotes cyclin D1/cdk4 assembly, which forwards cell cycle progression. ${ }^{17}$ Here we show that overexpression of thioredoxin reductase through 
treatment of cells with erucin decreases phosphorylation of p27 at T157. This decrease is not seen when thioredoxin reductase 2 is overexpressed or Jab1 is underexpressed. (Figures 6A and 6B)

\section{Discussion}

As mentioned earlier, most studies on Trx and resistance to breast cancer treatment focus on Trx's anti-apoptotic role in high ROS-producing chemotherapies. For example, response to docetaxel, a potent anti-cancer drug used with breast cancer patients, is linked to thioredoxin, ${ }^{6}$ and Trx expression is correlated with platinum-based drug resistance. ${ }^{18}$

While these studies show the role of Trx as an agonist for chemotherapeutic drug resistance, we suggest that the role Trx plays in tamoxifen-treated breast cancer is affected by the overoxidation of Trx by the chronic low to medium levels of tamoxifeninduced ROS, and that this can play a role in anti-estrogen resistance. We suggest that the oxidative state of cells treated with anti-estrogens will add a constant state of oxidative stress, and will create an adaptation in the cellular mechanism that leads to resistance to antiestrogens, namely through an oxidation of thioredoxin.

We also suggest that altering Trx oxidation may alter tamoxifen-resistant cells' reactions to tamoxifen, and lead to a more sensitive cell. We found that reducing Trx through an increase in TrxR did lead to higher levels of growth arrest and fewer tumor formations (soft agar) in tamoxifen-treated cells. 
Tamoxifen is known to lead to an increase in ROS. ${ }^{19}$ Here we show that

overexpression of TrxR in tamoxifen treated resistant cells can reduce the amount of oxidized thioredoxin.

The role of Jab1 in tamoxifen resistance has not been explored. While Jab1 has been shown to bind to both $\mathrm{p} 27$ and Trx in HEK cells, ${ }^{4}$ this association has not been shown elsewhere. Here we show that altering the redox state of Trx leads to Jab1/Trx binding during tamoxifen treatment. We were unable to show a decrease in Jab1/p27 binding in these experiments.

The function of $\mathrm{p} 27$ is also important when looking at tamoxifen resistance. While we show that $\mathrm{p} 27$ levels rise when TrxR is overexpressed, more importantly we also show decreased levels of phosphorylated p27 at T157 and T187. This implies that the increased p27 may be able to function properly in its cell cycle inhibitory role. In total, our results show a possible role for thioredoxin and for Jab1 in the reversal of tamoxifen resistance. When Trx is reduced through overexpression of TrxR, or when Jab1 levels are decreased, we show changes in tamoxifen-resistant LCC2 breast cancer cells that imply a shift of the cell towards tamoxifen sensitivity.

\section{Reference List}

(1) Kaimul AM, Nakamura H, Tanito M, Yamada K, Utsumi H, Yodoi J. Thioredoxin-1 suppresses lung injury and apoptosis induced by diesel exhaust particles (DEP) by scavenging reactive oxygen species and by inhibiting DEPinduced downregulation of Akt. Free Radic Biol Med 2005;39(12):1549-1559. 
(2) Zhang Y, Shen X. Heat shock protein 27 protects L929 cells from cisplatininduced apoptosis by enhancing Akt activation and abating suppression of thioredoxin reductase activity. Clin Cancer Res 2007;13(10):2855-2864.

(3) Chang EY, Son SK, Ko HS, Baek SH, Kim JH, Kim JR. Induction of apoptosis by the overexpression of an alternative splicing variant of mitochondrial thioredoxin reductase. Free Radic Biol Med 2005;39(12):1666-1675.

(4) Hwang CY, Ryu YS, Chung MS et al. Thioredoxin modulates activator protein 1 (AP-1) activity and $\mathrm{p} 27 \mathrm{Kip} 1$ degradation through direct interaction with Jab1. Oncogene 2004;23(55):8868-8875.

(5) Donovan JC, Milic A, Slingerland JM. Constitutive MEK/MAPK activation leads to $\mathrm{p} 27$ (Kip1) deregulation and antiestrogen resistance in human breast cancer cells. J Biol Chem 2001;276(44):40888-40895.

(6) Iwao-Koizumi K, Matoba R, Ueno $\mathrm{N}$ et al. Prediction of docetaxel response in human breast cancer by gene expression profiling. J Clin Oncol 2005;23(3):422431.

(7) Go YM, Jones DP. Thioredoxin Redox Western Analysis . Current Protocols in Toxicology Supplement 412009.

(8) Bacon JR, Plumb GW, Howie AF, Beckett GJ, Wang W, Bao Y. Dual action of sulforaphane in the regulation of thioredoxin reductase and thioredoxin in human HepG2 and Caco-2 cells. J Agric Food Chem 2007;55(4):1170-1176.

(9) Wang W, Wang S, Howie AF, Beckett GJ, Mithen R, Bao Y. Sulforaphane, erucin, and iberin up-regulate thioredoxin reductase 1 expression in human MCF7 cells. J Agric Food Chem 2005;53(5):1417-1421.

(10) Brown KK, Eriksson SE, Arner ES, Hampton MB. Mitochondrial peroxiredoxin 3 is rapidly oxidized in cells treated with isothiocyanates. Free Radic Biol Med 2008;45(4):494-502.

(11) Esteva FJ, Sahin AA, Rassidakis GZ et al. Jun activation domain binding protein 1 expression is associated with low p27(Kip1)levels in node-negative breast cancer. Clin Cancer Res 2003;9(15):5652-5659.

(12) Connor MK, Kotchetkov R, Cariou S et al. CRM1/Ran-mediated nuclear export of p27(Kip1) involves a nuclear export signal and links p27 export and proteolysis. Mol Biol Cell 2003;14(1):201-213.

(13) Alkarain A, Jordan R, Slingerland J. p27 deregulation in breast cancer: prognostic significance and implications for therapy. J Mammary Gland Biol Neoplasia 2004;9(1):67-80. 
(14) Alkarain A, Slingerland J. Deregulation of p27 by oncogenic signaling and its prognostic significance in breast cancer. Breast Cancer Res 2004;6(1):13-21.

(15) Planas-Silva MD, Hamilton KN. Targeting c-Src kinase enhances tamoxifen's inhibitory effect on cell growth by modulating expression of cell cycle and survival proteins. Cancer Chemother Pharmacol 2007;60(4):535-543.

(16) Slingerland J, Pagano M. Regulation of the cdk inhibitor p27 and its deregulation in cancer. J Cell Physiol 2000;183(1):10-17.

(17) Hong F, Larrea MD, Doughty C, Kwiatkowski DJ, Squillace R, Slingerland JM. mTOR-raptor binds and activates SGK1 to regulate p27 phosphorylation. $\mathrm{Mol}$ Cell 2008;30(6):701-711.

(18) Azuma K, Komohara Y, Sasada T et al. Excision repair cross-complementation group 1 predicts progression-free and overall survival in non-small cell lung cancer patients treated with platinum-based chemotherapy. Cancer Sci 2007;98(9):1336-1343.

(19) Kallio A, Zheng A, Dahllund J, Heiskanen KM, Harkonen P. Role of mitochondria in tamoxifen-induced rapid death of MCF-7 breast cancer cells. Apoptosis 2005;10(6):1395-1410.

\section{Figures}

Figure 1-LCC2 


\section{Upregulation of cellular and mitochondrial thioredoxin reductase reduced the} formation of anchorage-independent colonies in tamoxifen-resistant cells. Wild type and cells overexpressing TrxR 1 and 2 were treated with either $0.1 \%$ DMSO or $1 \mu \mathrm{M}$ tamoxifen and $1 \mu \mathrm{M}$ fulvestrant (positive control) in soft agar for over 14 days. (A) Tamoxifen-resistant LCC2 cells were transfected with pCMV6-XL4 plasmid to overexpress mitochondrial thioredoxin reductase 2 . Representative pictures of colonies with transfections and treatments as noted. (B) LCC2 cells were treated with $10 \mu \mathrm{M}$ Erucin as well as other treatments as noted. (D \& E) Graphic representation of colony counts with treatments as noted. Data shown are representative of minimum three independent experiments and are presented as number of colonies +/- SD. Values that are significantly different from empty vector control (TrxR2 overexpression) or DMSO (erucin treatment) are marked with an asterisk $(*)$, and those significantly different from tamoxifen treatment are marked with two asterisks $(* *)$. 


\section{Downregulation of Jab1 reduced the formation of anchorage-independent colonies}

in tamoxifen-treated tamoxifen-resistant LCC2 cells. Wild type LCC2 cells and LCC2 cells underexpressing Jab1 were treated with either $0.1 \%$ DMSO or $1 \mu \mathrm{M}$ tamoxifen in soft agar for over 14 days. (C) LCC2 cells were transfected with HuSH purified pRS plasmid to underexpress Jab1. Representative pictures of colonies with transfections and treatments as noted. (F) Graphic representation of colony counts with treatments as noted. Data shown are representative of three independent experiments. Values that are significantly different from empty vector control (TrxR2 overexpression) or DMSO (Erucin treatment) are marked with an asterisk $(*)$, and those significantly different from tamoxifen treatment are marked with two asterisks $(* *)$. Data are presented as number of colonies $+/$ - SD. Values that are significantly different $(\mathrm{p}<0.05)$ from empty vector control are marked with an asterisk (*).

\section{Figure 2-LCC2}




\section{Upregulation of cellular and mitochondrial thioredoxin reductase decreased DNA}

synthesis in tamoxifen-treated tamoxifen-resistant LCC2 cells. Cells were treated to overexpress thioredoxin reductase, then treated with either $0.1 \%$ DMSO or $1 \mu \mathrm{M}$ tamoxifen and $1 \mu \mathrm{M}$ fulvestrant (positive control) for 48 hours. (A) Tamoxifen-resistant LCC2 cells were transfected with pCMV6-XL4 plasmid to overexpress mitochondrial thioredoxin reductase 2, then treated as noted in Materials and Methods section. (B) LCC2 cells were treated with $10 \mu \mathrm{M}$ Erucin for 48 hours in serum-free media. Afterwards, starvation media was removed, fresh serum-free media added, and cells were treated as noted. Data shown are representative of minimum three independent experiments and are presented as absorbance reading +/- SD. Values that are significantly different from empty vector control (TrxR2 overexpression) or DMSO (erucin treatment) are marked with an asterisk $(*)$, and those significantly different from tamoxifen treatment are marked with two asterisks $(* *)$.

\section{Downregulation of Jab1 also decreases DNA synthesis in tamoxifen-treated}

tamoxifen-resistant LCC2 cells. (C) Cells were treated to underexpress Jab1, incubated in serum-free media 48 hours, then treated with either $0.1 \%$ DMSO, $1 \mu \mathrm{M}$ tamoxifen, or $1 \mu \mathrm{M}$ fulvestrant (positive control) for 48 hours. Data shown are representative of minimum three independent experiments and are presented as absorbance $+/-$ SD. Values that are significantly different from empty vector control are marked with an asterisk $(*)$. 
Figure 3-LCC2

\section{Upregulation of TrxR2 and TrxR2 with plasmid overexpression or isothiocyanate treatment increases Trx2 and Trx expression in addition to TrxR2 and TrxR} expression in LCC2 cells. (A) LCC2 cells were transfected with plasmid to overexpress TrxR2. Treatments were administered as noted in Materials and Methods section. (B) LCC2 cells were serum starved 48 hours during which specified cells were treated with $10 \mu \mathrm{M}$ sulforaphane. After starvation, media was replaced with fresh serum-free media, and cells were treated as noted. Cells were collected after 48 hours for protein analysis.

\section{Figure 4-LCC2}


Thioredoxin oxidation in tamoxifen resistant cells may be reversible. (A) Tamoxifenresistant LCC2 cells were transfected with pCMV6-XL4 plasmid to overexpress mitochondrial thioredoxin reductase 2, and (B) LCC2 cells were treated with $10 \mu \mathrm{M}$ erucin for 48 hours in serum-free media. Cells were then exposed to either $0.1 \%$ DMSO or $1 \mu \mathrm{M}$ tamoxifen for 30 minutes. Cells were lysed and lysate run through redox western protocol as noted in Materials and Methods section. Data shown are representative, and are presented as $(\mathrm{C})$ redox potential of thioredoxin.

Figure 5-LCC2 
Upregulation of cellular and mitochondrial thioredoxin reductase increases Jab1/ Trx binding and decrease Jab1 p27 binding in tamoxifen-treated tamoxifenresistant LCC2 cells. Cells were treated to overexpress thioredoxin reductase, then treated with either $0.1 \%$ DMSO or $1 \mu \mathrm{M}$ tamoxifen for 48 hours. LCC2 cells overexpressing mitochondrial thioredoxin reductase by pretreatment with $10 \mu \mathrm{M}$ isothiocyanate for 48 hours in serum-free media were harvested for coimmunoprecipitation after 48 hours of treatment. (A) After immunoprecipitation of Jab1 with anti-Jab1 antibody, precipitated proteins were probed with anti-Trx antibody. Trx binding was seen as greatly enhanced in sulforaphane pretreated/tamoxifen treated cells. (B) After immunoprecipitation of Jab1, precipitated proteins were probed with anti-p27 antibody. Jab1/p27 binding was decreased as compared to cells without erucin pretreat. Figure 6-LCC2 


\section{C}

\section{Overexpression of TrxR1 through erucin treatment decreases p27 phosphorylation}

at T157 and T187. LCC 2 cells were serum starved 48 hours during which specified cells were treated with $10 \mu \mathrm{M}$ erucin. After starvation, media was replaced with fresh serumfree media, and cells were treated as noted. Cells were collected after 48 hours of treatment for protein analysis. LCC2 cells were treated with $0.1 \%$ DMSO or $1 \mu \mathrm{M}$ tamoxifen. (A) Expression of phosphorylated p27 at T157 and T187 before and after overexpression of TrxR2 and TrxR1 through erucin treatment. (B) Quantification of protein expression (T157). Phosphorylated/total p27 ratio was normalized to $\beta$-actin. (C) Quantification of protein expression (T187). Phosphorylated/total p27 ratio was normalized to $\beta$-actin. Data shown are representative of two independent experiments and are presented as protein expression amounts.

Underexpression of Jab1 decreases p27 phosphorylation at T187. LCC2 cells were serum starved 48 hours, then media replaced with fresh serum-free media, and cells treated with $0.1 \%$ DMSO or $1 \mu \mathrm{M}$ tamoxifen. Cells were collected after 48 hours of treatment for protein analysis. (A) Expression of phosphorylated p27 at T157 and T187 
with and without underexpression of Jab1. (B) Quantification of protein expression (T157). Phosphorylated/total p27 ratio was normalized to $\beta$-actin. (C) Quantification of protein expression (T187). Data shown are representative of two independent experiments and are presented as protein expression amounts.

\title{
IV INCREASED THIOREDOXIN REDUCTASE OR DECREASED JAB1 LEADS TO DECREASED GROWTH IN BREAST CANCER CELLS UPON ESTROGEN TREATMENT THROUGH DECREASED AKT AND P27 PHOSPHORYLATION
}

\begin{abstract}
It is known that estrogen increases ROS in breast cancer cells. Thioredoxin, an enzymatic antioxidant, reduces proteins that have been oxidized by ROS. We wanted to show that mild oxidants such as estrogen could oxidize thioredoxin, causing it to be inactive and unable to reduce other proteins. This alteration in an antioxidant could lead to furthering cell proliferation by changing the redox state of the cell and leading to an increase in cell cycle pathways that lead to proliferation, such as the PI3K pathway. This increase in proliferation signaling could be a pathway for resistance to treatments such as tamoxifen, which has also been shown to produce ROS in low to medium doses. For this study we looked at how overexpressing thioredoxin reductase or underexpressing Jab1 affects estrogen-mediated cell proliferation in the breast cancer epithelial cell line MCF-7, as well as the effects of oxidized thioredoxin on Akt and p27 phosphorylation. We show that estrogen oxidizes thioredoxin, and that this is reversed with the overexpression of
\end{abstract}


thioredoxin reductase. We also show that thioredoxin reductase overexpression in MCF-7 cells decreases Akt phosphorylation, increases p27 expression, and decreases p27 phosphorylation. This data implies a role for antioxidants in altering estrogen-mediated growth of breast cancer cells. As we have already shown that it plays a role in altering tamoxifen resistance in breast cancer cells, this data may imply a role for thioredoxin reductase in preventing tamoxifen resistance.

\section{Introduction}

Estrogen actions with estrogen receptors are well known to promote pre-neoplastic and malignant growth. The estrogen / estrogen receptor combination can directly interact with the estrogen response element, or can act through a non-genomic pathway. ${ }^{1}$ Estrogen mechanisms in breast cancer cells have more recently included the production of intracellular ROS, leading to cell signaling and growth of estrogen-dependent breast cancer cells. ${ }^{2}$ At moderate levels, ROS can use reversible protein oxidation to regulate signaling pathways, most especially in PTPs. ${ }^{4}$ An important role of PTPs and PTKs is their ability to turn on and off the action of the protein on which they are exerting their influence. ${ }^{5}$ Structural changes to PTPs are induced by ROS, and the altered protein conformation leads to signaling cascade upregulation. ${ }^{6}$ Oxidation of PTPs can be reversed by thiol compounds ${ }^{7}$ such as thioredoxin (Trx), a $12 \mathrm{kDa}$ disulphide reducing enzyme $^{8,9}$ that is induced by stressors such as $17 \beta$-estradiol. ${ }^{10}$

The redox state of Trx is important to its function, and as such, the role of Trx reductase (TrxR) is key. In both Trx and TrxR there are cysteine molecules that are key to redox regulation. ${ }^{8,9}$ Trx reductases are NADPH-dependent, and they catalyze disulfide 
reduction at thioredoxin active sites. In turn, reduced thioredoxins catalyze the movement of active site dithiols to a disulfide state. This process has given the thioredoxin family a crucial role in cell-growth and apoptosis, as it is through this process they can regulate enzymes such as ribonucleotide reductase, peroxiredoxins and transcription factors. ${ }^{11}$

The PTP PTEN is a phosphoinositol 3' kinase (PI3K) inhibitor. A downstream molecule in the PI3K pathway, protein kinase B (Akt), can phosphorylate p27 at T157 and inhibit its import to the nucleus, prohibiting p27 from inhibiting cell proliferation. ${ }^{12}$ Overexpression of the PTEN gene increases p27 levels, decreases cyclin D1 levels, inhibits the phosphorylation of Akt, and through these mechanisms inhibits cell growth in MCF-7 cells. ${ }^{13}$ The tumor suppressor PTEN can be reduced by Trx. ${ }^{14}$

Several studies have explored the link between estrogen, estrogen receptor (ER) and thioredoxin. For example, the breast cancer cell line ZR-75-1 has been used to show that $\mathrm{H}_{2} \mathrm{O}_{2}$ treatment leads to a decrease in levels of $\mathrm{pS} 2$, a gene induced by estrogen. When, however, cells were transfected with thioredoxin, the expression of $\mathrm{pS} 2$ was restored in the $\mathrm{H}_{2} \mathrm{O}_{2}$-treated cells. ${ }^{15}$ Another study has shown that Trx expression may be correlated with better prognosis in ER+ and p53-intact patients. ${ }^{16}$ In the mouse uterus, estrogen treatment increases Trx, Trx 2 , and TrxR expression, as evidenced by mRNA levels. ${ }^{17}$ In a study regarding estrogen and congestive heart failure, subcutaneous, slow release pellets of estrogen ( $0.5 \mathrm{mg} / 60$ day release) offered antioxidative properties. These properties were also associated with an increase in the expression of $\operatorname{Trx}$, TrxR, and TrxR activity. In this form, estrogen also reduced ASK-1 activation, JNK activation, and p38 MAPK, 
which can all be related to the increase in availability of thioredoxin. These data may show that thioredoxin could be conferring the antioxidative properties that are being linked to estrogen. ${ }^{18}$

In considering breast cancer and its treatment, it is important to also explore the cell signaling pathways that occur due to estrogen exposure in ER+ cells, as well as those initiated by the treatments. While both Trx mRNA and protein are increased with 17ßestradiol treatment, this effect is suppressed when tamoxifen treatment is given. ${ }^{10}$ Both estrogen and tamoxifen have been shown to increase levels of ROS in breast cancer cells. ${ }^{19}$ ROS can initiate signal transduction cascades that have been shown to lead to cell proliferation. ${ }^{3}$ In this study, we explore the role thioredoxin may have in reversing estrogen-mediated cell signaling. In particular, we look at the effect of oxidized Trx on PTEN function, as well as the downstream targets of Akt and phosphorylated p27. We find that altering the oxidative state of breast cancer cells with thioredoxin reductase leads to a decrease in cell growth through decreasing Akt phosphorylation, and subsequently decreasing phosphorylation of p27 at T157.

\section{Materials and methods}

Cell lines and cultures: Human breast adenocarcinoma MCF-7 cells were propagated in phenol red free Dulbecco's Modified Eagle Medium/F12 (DMEM/F12) with L-Glutamine and 15mM HEPES (Invitrogen, Grand Island, NY; Mediatech, Manassas, VA) containing 10\% (v/v) fetal bovine serum (Invitrogen; Atlanta Biologicals Lawrenceville, GA), 
$100 \mathrm{u} / \mathrm{mL}$ penicillin $\mathrm{G}$ sodium, and $100 \mathrm{ug} / \mathrm{mL}$ streptomycin sulfate (Invitrogen) at $37^{\circ} \mathrm{C}$ in $5 \% \mathrm{CO}_{2}$ atmosphere.

Antibodies: All antibodies used were purchased from Santa Cruz (Santa Cruz, CA), except the following: GAPDH (Sigma), $\beta$-actin (Sigma), and p27 phosphorylated at T157 (Abcam, Cambridge, MA).

Chemicals and experimental protocol: Erucin was purchased from LKT Laboratories (St. Paul, MN). DMSO and 17ß-estradiol were purchased from Sigma (St. Louis, MO). For experimental purposes, cells were seeded in 10\% FBS DMEM/F12 medium and allowed to adhere overnight. Culture medium was replaced with serum-free DMEM/F12 and allowed to grow for $48 \mathrm{~h}$ (starvation), followed by treatments as described in figure legends. For cells with erucin treatment, $10 \mu \mathrm{M}$ erucin was added with the DMEM/F12 without FBS for the starvation period of $48 \mathrm{~h}$ in order to overexpress thioredoxin reductase 1 (TrxR1). Media with erucin was then removed, fresh serum-free media added without erucin, and treatments added.

Transfection procedures: pRS shRNA vector without shRNA cassette insert, pRS HuSH 29mer shRNA constructs against COPS5 (Jab1), and pCMV6-XL4 carrying the fulllength human TrxR2 cDNA (OriGene Technologies, Rockville, MD, USA) were purified using MAX Efficiency® DH5 $\alpha^{\mathrm{TM}}$ Competent Cells (Invitrogen) and plasmid was extracted using phenol extraction and ethanol precipitation. For transfection, cells were seeded in 6-well plates at 70\%. After overnight incubation, transfection was performed 
using Fugene (1:3) (Roche, Indianapolis, IN) and left to incubate overnight in Optimem (Invitrogen) or DMEM/F12 without serum or antibiotics. The next day media was changed to growth media, and cells were seeded the following day. HuSH 29-mer non-effective (scrambled) pRS vector (Origene) was tested and showed similar actions to the empty plasmid vector (data not shown).

Soft agar colony formation assay: Cells were seeded at a concentration of 500 cells/well (48-well plates) in $0.25 \%$ agarose on a $0.5 \%$ agarose base in DMEM/F 12 with $10 \%$ FBS. Cells were fed two times per week with treatments as described in figure legends, and colonies were counted on day 16 . Each assay was performed with triplicate treatments.

BrdU cell proliferation assay: Cells were seeded at 2500 cells/well in $96-$ well plates in serum-free DMEM/F12 for $48 \mathrm{~h}$ (certain wells also including $10 \mu \mathrm{M}$ erucin as described earlier). Treatments were added as described in figure legends for $48 \mathrm{~h}$. A colorimetric BrdU cell proliferation assay was performed according to the manufacturer's instructions (Roche). After incubation, the cells were labeled with $\mathrm{BrdU}$ for 24 hours at $37^{\circ} \mathrm{C}$ in $5 \%$ $\mathrm{CO} 2$. After $30 \mathrm{~m}$ of fixation/denaturing, cells were incubated with anti-BrdU-peroxidase antibody (1:1000) for $90 \mathrm{~m}$. Cells were then washed three times with 1x PBS, and the final substrate added. The absorbance was measured at a wavelength of $370 \mathrm{~nm}$ and a reference wavelength of $492 \mathrm{~nm}$ at time points from 5-30 $\mathrm{m}$ at $5 \mathrm{~m}$ intervals.

Immunoblot: Cells were seeded in $100 \mathrm{~mm}$ plates at $1 \times 10^{6}$ cells in $10 \%$ FBS DMEM/F12 and allowed to grow overnight. Cells were then starved for 48 hours, then treated with DMSO and 17ß-estradiol (E2) for $48 \mathrm{~h}$. Cells were then rinsed with cold PBS, lysed (150 
$\mathrm{mM} \mathrm{NaCl}, 1 \% \mathrm{NP}-40,0.5 \%$ sodium deoxycholate, $0.1 \%$ SDS (sodium dodecyl sulphate), $50 \mathrm{mM}$ Tris, $\mathrm{pH} 8.00 .2 \mathrm{mM} \mathrm{Na}_{3} \mathrm{VO}_{4}, 50 \mathrm{mM} \mathrm{NaF}, 1 \mathrm{x}$ complete protease inhibitor (Roche)), and proteins isolated. Quantification of proteins was performed using the BCA assay (Pierce, Rockford, IL), and lysate was boiled for $5 \mathrm{~m}$ at $95-100^{\circ} \mathrm{C}$. Acrylamide gel (12\%) was loaded with $100 \mu \mathrm{g}$ protein, and run for $2.5 \mathrm{~h}$ at 150 volts. Proteins were transferred to PVDF, and blots were blocked with either 5\% milk or blocking buffer for phosphorylated proteins ( $1 \%$ milk, $1 \% \mathrm{BSA}, 50 \mathrm{mM} \mathrm{NaF}$ ) in TBS-T. Blots were then incubated with primary antibodies overnight. Secondary antibodies were added for one hour, and blots were developed using either a film developer (Konica Minolta) or VersaDoc imaging system using QuantityOne software (BioRad). ImageJ software (NIH) was used to quantify the protein expression through densitometry. This software was used for all assays that required densitometry.

PTEN Redox Western: Cells were seeded in 6 well plates at 400,000 cells / well in 10\% FBS DMEM/F12 and allowed to grow overnight. Cells were then grown in DMEM/F12 without serum for $48 \mathrm{~h}$, and then treated with DMSO and $17 \beta$-estradiol for $30 \mathrm{~m}$ in $1 \mathrm{~mL}$ of starvation media. Cells were scraped in the media and treatment, and placed in $1.5 \mathrm{~mL}$ tube containing $200 \mathrm{uL}$ of ice-cold 50\% trichloroacetic acid. Cells and media were sonicated briefly, and then centrifuged at $2000 \mathrm{x}$ g for $5 \mathrm{~m}$. Supernatant was removed, and the pellet was washed with acetone. After centrifuging again, supernatant was removed, and $200 \mathrm{uL}$ lysis buffer was added (100 mm Tris- $\mathrm{HCl}$ (pH 6.8), 2\% SDS, 40 mM NEM). 30-50 uL of lysate was run under non-reducing conditions using SDS-PAGE. 
Thioredoxin Redox Western: The procedure for redox western for thioredoxin has been described in detail. ${ }^{20}$ Briefly, MCF-7 cells were seeded at either 400,000 cells / well (6 well plate) or $1 \times 10^{6}$ cells/plate (100 mm plates). After overnight incubation, serum-free media was added to all wells, with $10 \mu \mathrm{M}$ erucin added to certain wells/plates. After $48 \mathrm{~h}$, cells were treated as noted in figures for $30 \mathrm{~m}$. After washing $2 \mathrm{x}$ with PBS, G lysis buffer with $50 \mathrm{mM}$ iodoacetic acid was added and cells were scraped into $1.5 \mathrm{~mL}$ tubes. Samples were incubated for $30 \mathrm{~m}$ at $37^{\circ}$. Lysate was sonicated briefly, then centrifuged for $3 \mathrm{~m}$ at $2000 \mathrm{x} \mathrm{g}$ at room temperature. Lysate was transferred to new tubes, and BCA assay was performed to quantitate the proteins. $50 \mu \mathrm{g}$ was loaded in a native separating gel $(15 \%)$ under non-reducing conditions and run for $90 \mathrm{~m}$ at $150 \mathrm{~V}$ in native running buffer. Proteins were transferred to PVDF, incubated in 5\% BSA for $1 \mathrm{~h}$, then incubated in anti-Trx antibody overnight. An SDS-PAGE (12\%) was also run with the same lysate for loading control GAPDH or B-actin. Films or Versadoc images were subjected to densitometry using ImageJ software.

Redox potential (Eh) of Trx1 was calculated using the Nernst equation through the use of the reduced and oxidized bands of thioredoxin. The equation Eh $(\mathrm{mV}$, redox potential $)=$ Eo $($ midpoint potential $)+(\mathrm{RT} / \mathrm{nF}) \ln (\operatorname{Trx} 1 \mathrm{Ox} / \operatorname{Trx} 1 \mathrm{Red})$ was used, where $\mathrm{Eo}=-240 \mathrm{mV}$ for $\operatorname{Trx} 1$ at $\mathrm{pH} 7.0$ and $25^{\circ} \mathrm{C}, 30=\ln$ and $\mathrm{RT} / \mathrm{nF}$ (this was calculated previously by Go and Jones by using values [R, universal gas constant; $T$, absolute temperature; n, number of electrons; F, Faraday constant]). The ratio of oxidized and reduced Trx1 bands (Trx1 Ox/Trx1 Red) band intensities were taken for each sample 
and used to calculate $\ln (\operatorname{Trx} 10 x / \operatorname{Trx} 1$ Red). Thus, the final equation (as calculated by Go and Jones) reduces to Eh, $\operatorname{Trx} 1=-240 \mathrm{mV}+30 \times \ln ($ ratio of $\operatorname{Trx} 1 \mathrm{Ox}$ and $\operatorname{Trx} 1 \mathrm{Red})$.

\section{Results}

\section{Upregulation of TrxR or downregulation of Jab1 suppresses anchorage-} independent growth and DNA synthesis in estrogen-treated MCF-7 cells

Estrogen is known to lead to cell growth in MCF-7 cells. Our lab has shown the induction of mitochondrial ROS (mtROS) in estrogen-dependent breast cancer cells upon estrogen treatment. We have also shown the effect of antioxidants, such as ebselen and NAC, on reducing these mtROS, and subsequently on the reduction of estrogen-mediated growth in MCF-7 cells. For these experiments, we wanted to explore the role of thioredoxin reductase 1 and 2 on estrogen-mediated growth in MCF-7 cells.

Anchorage-independent growth is a hallmark of tumor cells. As such, we performed a colony formation assay in soft agar with MCF-7 cells, MCF-7 cells transfected with Jab1 shRNA to underexpress Jab1, MCF-7 cells transfected to overexpress TrxR2, and MCF-7 cells that were co-treated with erucin to increase TrxR1. Cells were treated for over 2 weeks, and colonies counted. Figures 1A, 1B, and 1C show representative pictures and graphic representations of these counts. We found that the overexpression of TrxR2 through transfection and TrxR1 through the treatment with erucin decreased both DMSO and estrogen treated cells significantly. (Figure 1A and 1B) Underexpression of Jab1 also showed a decrease in estrogen-treated cells. (Figures 1C and 1F) These data show a role 
for increased reduced thioredoxin or decreased Jab1 expression in reducing estrogenmediated growth of tumor cells.

We also looked at the DNA synthesis (cell proliferation) of these cells through the use of the BrdU incorporation assay (Figures 2A, 2B, and 2C) and found that all three cellular modulations led to a decrease in DNA synthesis. These data suggest that an increase of thioredoxin reductase, both cellular and mitochondrial, will decrease estrogen-mediated growth of MCF-7 epithelial cancer cells, supposedly through the reduction of thioredoxin 1 and thioredoxin 2 and subsequent reduction of other cell cycle proteins. It also suggests a role for Jab1 in estrogen-mediated growth of breast cancer.

\section{Thioredoxin is reversibly oxidized by estrogen treatment, and reduced after the upregulation of TrxR}

Estrogens are phenolic chemicals, (Roy and Liehr, 1990) and are known to lead to the production of mitochondrial ROS. ${ }^{19,21}$ MtROS have been implicated in cell signaling in several pathways, including integrins, platelet-derived growth factor, epidermal growth factor, and nerve growth factor. ${ }^{22}$ We confirmed the increase of ROS by estrogen by measuring $\mathrm{H}_{2} \mathrm{O}_{2}$ production through the DCF assay. (Data not shown) One of the three major redox couples that are responsive to changes in the reducing/oxidizing (redox) environment in cells is $\operatorname{Trx}(\mathrm{SS}) / \operatorname{Trx}(\mathrm{SH}) 2{ }^{23}$ There are several published examples of Trx's susceptibility to ROS, and there are a variety of compounds that have been found to

oxidize Trx, such as $\mathrm{H}_{2} \mathrm{O}_{2}$ and superoxide. ${ }^{24}$ While it has been shown that estrogen treatment increases thioredoxin and thioredoxin reductase levels in bovine aortic 
endothelial cells, we wanted to test if the mtROS produced by estrogen would have an oxidative effect on thioredoxin. We performed a redox western to explore the effects of estrogen treatment on the redox state of thioredoxin. Cells were treated for $30 \mathrm{~m}$ before lysates were prepared. $50 \mathrm{mM}$ iodoacetic acid was used in $6 \mathrm{M}$ guanidine lysis buffer, as it leads to thiol alkylation. When a thiol is modified, one negative charge is added, and reduced thioredoxin, which will have a negative charge after IAA treatment, will run faster than oxidized thioredoxin in a native, non-reducing gel electrophoresis. ${ }^{20}$

We found that estrogen treatment increases thioredoxin oxidation (Figure 3A) and, utilizing the Nernst equation as described in Materials and Methods, found that estrogen decreases thioredoxin redox potential (Figure 3B). The dietary isothiocyanates sulforaphane, erucin, and iberin have been found to induce thioredoxin reductase in MCF-7 cells. ${ }^{25}$ We wanted to explore if this chemical induction of TrxR would change the redox state of thioredoxin that was oxidized by estrogen. In HepG2 and undifferentiated Caco-2 cells, not only does sulforaphane induce TrxR, but also its substrate Trx. ${ }^{26}$ We found this to also be true of pretreating with erucin on the MCF-7 sub line LCC-2 cells.

We found that there is an overall increase in thioredoxin due to erucin treatment, and there is an increase in the amount of reduced thioredoxin in erucin+estrogen-treated cells in relation to those treated with the vehicle (DMSO). Erucin, however, also increases the amount of both TrxR and Trx, and has been shown to increase oxidation of glutathione reductase, thioredoxin reductase and peroxiredoxin 3 . We found that the redox potential 
of thioredoxin went down with isothiocyanate treatment, but feel this avenue deserves further research, as the amount of reduced thioredoxin increased dramatically. As the goal of this experiment was to ensure an increase in reduced thioredoxin, and not necessarily only an increase in oxidized/reduced thioredoxin ratio, we felt the use of isothiocyanates achieved this goal.

We explored if increasing the mitochondrial thioredoxin reductase (TrxR2) through transfection would have an effect on the oxidative state of cellular thioredoxin. (Figures $3 \mathrm{C}$ and 3D) We found that not only is there a decrease in the oxidation level of Trx (and an increase in redox potential) after this overexpression, there is an unexpected increase in thioredoxin redox potential when Jab1 is underexpressed.

These experiments show that the oxidation of thioredoxin by estrogen can be reduced with the use of an overexpression of thioredoxin reductase or the underexpression of Jab1. The oxidation of Trx can lead to its inactivity, which can affect several cell signaling pathways. For this study we explored PTEN oxidation and thioredoxin's role in reducing PTEN and restoring its function.

\section{Upregulation of TrxR through transfection decreases the ratio of oxidized to} reduced PTEN

ROS plays a redox regulatory role in protein-tyrosine phosphatases (PTPs). Its signature motif allows for redox regulation of proteins when the cysteine residues react with ROS. ${ }^{4}$ The PTP catalytic cysteine only requires mild oxidative conditions to be oxidized to 
sulfenic acid (Cys-SOH). This can be averted by interactions with a protein structure such as a thiol. ${ }^{4,5,27,28}$ We first checked for oxidation of PTEN by estrogen through nonreducing SDS-PAGE. MCF-7 cells were transfected with TrxR2 or pretreated with erucin, then treated with estrogen for $30 \mathrm{~m}$. We found that cells that were transfected with thioredoxin reductase reduced the ratio of oxidized/reduced PTEN in cells treated with estrogen (Figure 4A and B) We did not see similar results in cells pretreated with erucin to overexpress TrxR (data not shown). This may be due to the treatment time used.

\section{Downstream signaling of phosphorylated Akt is altered by modulation of thioredoxin reductase and Jab1}

PTEN is known to inhibit phosphoinositol 3' kinase (PI3K). A downstream molecule in the PI3K pathway is protein kinase B (Akt), which can phosphorylate, and thus inactivate, the cell cycle inhibitor p27. We wanted to explore if the oxidation or oxidation and then reduction of PTEN had an effect on this pathway. We performed a western blot on MCF-7 cells that had been treated with estrogen, pretreated with erucin and/or transfected with TrxR2 cDNA or Jab1 shRNA. We found that while estrogen increases the expression of phosphorylated Akt at S473, increasing the expression of thioredoxin reductase 2 alters this estrogen-mediated phosphorylation, as seen in Figure 5A and B. We were not able to show that the chemical overexpression of TrxR through the use of erucin also decreases phosphorylation of Akt (data not shown). Again, this could be due to the treatment times chosen for this experiment. However, again unexpectedly, the downregulation of Jab1 also showed a decrease in Akt phosphorylation. 


\section{Overexpression of TrxR or underexpression of Jab1 alters p27 phosphorylation}

at $\mathbf{T} 157$

Protein kinase B (Akt) can phosphorylate p27 at T157 and inhibit its import to the nucleus. This prohibits p27 from inhibiting cell proliferation. ${ }^{12}$ When $\mathrm{p} 27$ is in the cytoplasm, it aids in the assembly of cyclin D1/cdk4, which furthers cell proliferation. ${ }^{29}$ When the PI3K pathway has been activated, as it is in human cancers, it has been found that $\mathrm{p} 27$ concentrations decrease. This effect is reversed by PTEN. ${ }^{30}$ Overexpression of the PTEN gene increases p27 levels, decreases cyclin D1 levels, inhibits the phosphorylation of Akt, and through these mechanisms inhibits cell growth in MCF-7 cells. ${ }^{13}$ We wanted to explore the effect of an increase of thioredoxin through an overexpression of thioredoxin reductase on $\mathrm{p} 27$ phosphorylation at $\mathrm{T} 157$. We performed a western blot as outlined in the Materials and Methods section (Figure 6A and D). We underexpressed Jab1 and overexpressed TrxR2 and pretreated with erucin to overexpress both cellular and mitochondrial TrxR (TrxR1 and TrxR2 respectively) and treated as noted in figures. We also scanned the blots and used ImageJ to quantify the blots (Figures $6 \mathrm{~B}, 6 \mathrm{C}, 6 \mathrm{E}, 6 \mathrm{~F})$. We found that the overexpression of both TrxR1 and TrxR2 led to a decrease in the PTEN downstream target of $\mathrm{p} 27$ phosphorylation at T157. This data paired with the data on PTEN shows a possible link between the oxidation of thioredoxin, oxidation of PTEN, and cell cycle progression through T157 phosphorylation of p27.

\section{Discussion}

Estrogen and tamoxifen produce intracellular ROS rapidly, which can lead to cell signaling and the growth of estrogen-dependent breast cancer cells. ${ }^{2,3,19}$ Upon ROS 
production there is a stimulus and a response to the ROS from a protein of either activation or inhibition, which is amplified through the activation or inhibition of effector molecules further downstream in the pathway. There is also reversibility so that the pathway can be responsive to more than just the one stimulus. Thioredoxin and glutathione, as well as enzymes that are associated with each, have been found to reduce the thiol oxidation that occurs through ROS. It has been compared to the regulatory effect of phosphorylation and de-phosphorylation of proteins. ${ }^{31}$

Thioredoxin and glutathione are the major factors in maintaining reduced proteins, ${ }^{6,32,33}$ and these reducing agents are found, in normal cells, in their reduced form. When they perform their reduction actions on oxidized proteins, they themselves are oxidized. They are then returned to their reduced forms through the use of thioredoxin reductase and glutathione reductase, respectively. Cysteine residues have been found to be specific targets for ROS when in the thiolate (-S) form, making them susceptible to modification by ROS.

Trx has been found to compete with p27 for binding with Jab1 in HEK293T (human embryonic kidney) cells, and, through this, negatively regulate p27 degradation. It has been shown that the addition of Trx to cells altered the direction of Jab1-induced p27 level decrease. In our study, we both overexpressed thioredoxin reductase to increase the amount of reduced, and thus active, thioredoxin, and underexpressed Jab1 through shRNA transfection to show a possible role for this pathway. We used these treatments on MCF-7 breast cancer cells to explore if altering the redox state of cells will alter 
estrogen-mediated growth. We found that overexpression of both thioredoxin reductase 1 and 2 reduces colony formation and cell proliferation effects of estrogen. We saw the same effects when we reduced Jab1 expression.

We explored the oxidation of thioredoxin by estrogen, and found that in MCF-7 cells thioredoxin is oxidized by estrogen. Overexpressing thioredoxin reductase, as would be expected, reversed these effects of estrogen. Interestingly, the reduction of Jab1 expression also led to a reduction in thioredoxin oxidation. We are unsure of the signaling pathway that may lead to this increase in redox potential by Jab1, and feel it deserves further study.

Particularly susceptible to oxidation are protein tyrosine phosphatases (PTPs) ${ }^{27,}{ }^{28}$ PTEN can be oxidized by $\mathrm{H}_{2} \mathrm{O}_{2}$, and then reduced by Trx. ${ }^{14}$ We found that estrogen-induced ROS oxidizes PTEN in MCF-7 cells, and that the addition of thioredoxin reductase reduces this oxidation. PTEN, as well as other PTPs, has been show to correlate with p27 levels. We wanted to explore if this pathway was affected by TrxR overexpression or Jab1 underexpression. A downstream molecule in the phosphoinositol 3' kinase (PI3K) pathway, protein kinase B (Akt) can phosphorylate p27 at T157 and inhibit its import to the nucleus. This prohibits p27 from inhibiting cell proliferation ${ }^{12}$ and makes it available for cyclin D1/cdk4 assembly which furthers cell cycle progression. ${ }^{29}$ When the PI3K pathway has been activated, as it is in human cancers, it has been found that p27 concentrations decrease ${ }^{30}$ We looked at the phosphorylation of Akt, and found it to be susceptible to estrogen and enzymatic antioxidants. The overexpression of thioredoxin 
reductase, presumably through the reduction of oxidized thioredoxin and subsequent reduction of oxidized PTEN, led to a decrease in phosphorylated Akt at S473. This decrease was also seen in cells that underexpressed Jab1. Further downstream in this pathway, the phosphorylation of p27 at T157 was decreased by altering TrxR and Jab1 levels in the cells.

\section{Reference List}

(1) Coleman KM, Smith CL. Intracellular signaling pathways: nongenomic actions of estrogens and ligand-independent activation of estrogen receptors. Front Biosci 2001;6:D1379-D1391.

(2) Roy D, Felty Q, Narayan S, Jayakar P. Signature of mitochondria of steroidal hormones-dependent normal and cancer cells: potential molecular targets for cancer therapy. Front Biosci 2007;12:154-173.

(3) Felty Q, Roy D. Estrogen, mitochondria, and growth of cancer and non-cancer cells. J Carcinog 2005;4(1):1.

(4) Salmeen A, Barford D. Functions and mechanisms of redox regulation of cysteine-based phosphatases. Antioxid Redox Signal 2005;7(5-6):560-577.

(5) Kang SW. Two axes in platelet-derived growth factor signaling: tyrosine phosphorylation and reactive oxygen species. Cell Mol Life Sci 2007;64(5):533541.

(6) Valko M, Leibfritz D, Moncol J, Cronin MT, Mazur M, Telser J. Free radicals and antioxidants in normal physiological functions and human disease. Int $J$ Biochem Cell Biol 2007;39(1):44-84.

(7) Chiarugi P, Cirri P. Redox regulation of protein tyrosine phosphatases during receptor tyrosine kinase signal transduction. Trends Biochem Sci 2003;28(9):509514.

(8) Nguyen P, Awwad RT, Smart DD, Spitz DR, Gius D. Thioredoxin reductase as a novel molecular target for cancer therapy. Cancer Lett 2006;236(2):164-174.

(9) Kondo N, Nakamura H, Masutani H, Yodoi J. Redox regulation of human thioredoxin network. Antioxid Redox Signal 2006;8(9-10):1881-1890. 
(10) Maruyama T, Sachi Y, Furuke K et al. Induction of thioredoxin, a redox-active protein, by ovarian steroid hormones during growth and differentiation of endometrial stromal cells in vitro. Endocrinology 1999;140(1):365-372.

(11) Chang EY, Son SK, Ko HS, Baek SH, Kim JH, Kim JR. Induction of apoptosis by the overexpression of an alternative splicing variant of mitochondrial thioredoxin reductase. Free Radic Biol Med 2005;39(12):1666-1675.

(12) Liang J, Zubovitz J, Petrocelli T et al. PKB/Akt phosphorylates p27, impairs nuclear import of p27 and opposes p27-mediated G1 arrest. Nat Med 2002;8(10):1153-1160.

(13) Weng LP, Brown JL, Eng C. PTEN coordinates G(1) arrest by down-regulating cyclin D1 via its protein phosphatase activity and up-regulating p27 via its lipid phosphatase activity in a breast cancer model. Hum Mol Genet 2001;10(6):599604.

(14) Lee SR, Yang KS, Kwon J, Lee C, Jeong W, Rhee SG. Reversible inactivation of the tumor suppressor PTEN by H2O2. J Biol Chem 2002;277(23):20336-20342.

(15) Hayashi S, Hajiro-Nakanishi K, Makino Y, Eguchi H, Yodoi J, Tanaka H. Functional modulation of estrogen receptor by redox state with reference to thioredoxin as a mediator. Nucleic Acids Res 1997;25(20):4035-4040.

(16) Matsutani Y, Yamauchi A, Takahashi R et al. Inverse correlation of thioredoxin expression with estrogen receptor- and p53-dependent tumor growth in breast cancer tissues. Clin Cancer Res 2001;7(11):3430-3436.

(17) Deroo BJ, Hewitt SC, Peddada SD, Korach KS. Estradiol regulates the thioredoxin antioxidant system in the mouse uterus. Endocrinology 2004;145(12):5485-5492.

(18) Satoh M, Matter CM, Ogita $\mathrm{H}$ et al. Inhibition of apoptosis-regulated signaling kinase- 1 and prevention of congestive heart failure by estrogen. Circulation 2007;115(25):3197-3204.

(19) Kallio A, Zheng A, Dahllund J, Heiskanen KM, Harkonen P. Role of mitochondria in tamoxifen-induced rapid death of MCF-7 breast cancer cells. Apoptosis 2005;10(6):1395-1410.

(20) Go YM, Jones DP. Thioredoxin Redox Western Analysis . Current Protocols in Toxicology Supplement 412009.

(21) Roy D, Cai Q, Felty Q, Narayan S. Estrogen-induced generation of reactive oxygen and nitrogen species, gene damage, and estrogen-dependent cancers. $J$ Toxicol Environ Health B Crit Rev 2007;10(4):235-257. 
(22) Thannickal VJ, Fanburg BL. Reactive oxygen species in cell signaling. Am J Physiol Lung Cell Mol Physiol 2000;279(6):L1005-L1028.

(23) Schafer FQ, Buettner GR. Redox environment of the cell as viewed through the redox state of the glutathione disulfide/glutathione couple. Free Radic Biol Med 2001;30(11):1191-1212.

(24) Lemarechal H, Anract P, Beaudeux JL, Bonnefont-Rousselot D, Ekindjian OG, Borderie D. Impairment of thioredoxin reductase activity by oxidative stress in human rheumatoid synoviocytes. Free Radic Res 2007;41(6):688-698.

(25) Wang W, Wang S, Howie AF, Beckett GJ, Mithen R, Bao Y. Sulforaphane, erucin, and iberin up-regulate thioredoxin reductase 1 expression in human MCF7 cells. J Agric Food Chem 2005;53(5):1417-1421.

(26) Bacon JR, Plumb GW, Howie AF, Beckett GJ, Wang W, Bao Y. Dual action of sulforaphane in the regulation of thioredoxin reductase and thioredoxin in human HepG2 and Caco-2 cells. J Agric Food Chem 2007;55(4):1170-1176.

(27) Salmeen A, Barford D. Functions and mechanisms of redox regulation of cysteine-based phosphatases. Antioxid Redox Signal 2005;7(5-6):560-577.

(28) Chiarugi P, Buricchi F. Protein tyrosine phosphorylation and reversible oxidation: two cross-talking posttranslation modifications. Antioxid Redox Signal 2007;9(1):1-24.

(29) Hong F, Larrea MD, Doughty C, Kwiatkowski DJ, Squillace R, Slingerland JM. mTOR-raptor binds and activates SGK1 to regulate p27 phosphorylation. $\mathrm{Mol}$ Cell 2008;30(6):701-711.

(30) Alkarain A, Slingerland J. Deregulation of p27 by oncogenic signaling and its prognostic significance in breast cancer. Breast Cancer Res 2004;6(1):13-21.

(31) Cooper CE, Patel RP, Brookes PS, rley-Usmar VM. Nanotransducers in cellular redox signaling: modification of thiols by reactive oxygen and nitrogen species. Trends Biochem Sci 2002;27(10):489-492.

(32) Valko M, Leibfritz D, Moncol J, Cronin MT, Mazur M, Telser J. Free radicals and antioxidants in normal physiological functions and human disease. Int $J$ Biochem Cell Biol 2007;39(1):44-84.

(33) Arner ES, Holmgren A. Physiological functions of thioredoxin and thioredoxin reductase. Eur J Biochem 2000;267(20):6102-6109. 
Figures

Figure 1-MCF7 


\section{Upregulation of cellular and mitochondrial thioredoxin reductase reduces the}

formation of anchorage-independent colonies in estrogen-treated ER+ breast cancer epithelial cells. MCF-7 cells were transfected to overexpress TrxR2 or were treated chemically with $10 \mu \mathrm{M}$ erucin to overexpress TrxR 1 and seeded in $0.25 \%$ agarose with DMEM and 10\% FBS. Cells were treated with either $0.1 \%$ DMSO or $100 \mathrm{pg}$ E2 for over two weeks. (A \& B) Representative pictures of wells demonstrating colonies formed by MCF-7 cells transfected and/or treated as indicated. Also shown, graphic representation of colony counts. Data shown are representative of three independent experiments and are presented as number of colonies +/- SD. Values that are significantly different $(\mathrm{p}<0.05)$ from empty vector control (TrxR2 overexpression) or DMSO (erucin treatment) are marked with an asterisk $(*)$.

\section{Downregulation of Jab1 reduced the formation of anchorage-independent colonies} in estrogen-treated ER+ breast cancer epithelial cells. MCF-7 cells were transfected with the HuSH pRS plasmid to underexpress Jab1. Wild type cells and cells underexpressing Jab1 were treated with either $0.1 \%$ DMSO or 100 pg E2 in soft agar for over 14 days. (C) Representative pictures of wells demonstrating colonies formed by MCF-7 cells transfected and treated as indicated. Also shown, graphic representation of colony counts. Data shown are a representative of two independent experiments performed in triplicate and are presented as number of colonies +/- SD. Values that are significantly different $(\mathrm{p}<0.05)$ from empty vector control are marked with an asterisk $(*)$ 
Figure 2-MCF7

\section{Upregulation of cellular and mitochondrial thioredoxin reductase decreased DNA} synthesis in estrogen-treated MCF-7 cells. Cells were treated to overexpress thioredoxin reductase, and then treated with either $0.1 \%$ DMSO or 100 pg E2 for 48 hours. (A) MCF-7 cells were transfected with pCMV6-XL4 plasmid to overexpress mitochondrial thioredoxin reductase 2, then treated as noted in the Materials and Methods section. (B) MCF-7 cells were treated with $10 \mu \mathrm{M}$ erucin for 48 hours in media without FBS. Afterwards, starvation media was removed, fresh media added, and treatments as noted were added. BrdU assay was performed as noted in Materials and Methods section. Data shown are representative of minimum three independent experiments and are presented as absorbance reading $+/$ - SD. Values that are significantly different from empty vector (TrxR2 overexpression) or DMSO (erucin treatment) are marked with an $\operatorname{asterisk}(*)$. 


\section{Downregulation of Jab1 decreased DNA synthesis in estrogen-treated MCF-7 cells.}

Cells were treated to overexpress thioredoxin reductase, and then treated with either $0.1 \%$ DMSO or 100 pg E2 for 48 hours. Data shown are representative of minimum three

independent experiments and are presented as absorbance reading +/- SD. Values that are significantly different from empty vector control (TrxR2 overexpression) or DMSO (erucin treatment) are marked with an asterisk $(*)$.

Figure 3-MCF7 


\section{Estrogen increases oxidative state of MCF-7 cells and leads to an increase in}

oxidation of Trx1. TrxR2 overexpression increases Trx redox potential. MCF-7 cells were seeded to 10-6 in $100 \mathrm{~mm}$ plates. After incubating overnight, cells were incubated with serum-free media for 48 hours. During this time, noted plates were treated with 10 $\mu \mathrm{M}$ erucin. After 48 hour incubation, cells were treated for 30 minutes with $0.1 \%$ DMSO or $100 \mathrm{pg}$ (100 ng in WT cells) $17 \beta$-estradiol. Cells were harvested in $50 \mathrm{mM}$ guanidine lysis buffer and prepared as described in Materials and Methods. (A) MCF-7 cells were treated with $10 \mu \mathrm{M}$ erucin for 48 hours in serum-free media, and (C) MCF-7 cells were transfected with pCMV6-XL4 plasmid to overexpress mitochondrial thioredoxin reductase 2. Cells were then exposed to either 0.1\% DMSO or 100 pg E2 for 30 minutes. Cells were lysed and lysate run through redox western protocol as noted in Materials and Methods section. Data for DTT (reductant) and H2O2 (oxidant) are also shown. (B \& D) Data are presented as redox potential of thioredoxin. Data shown are representative of three independent experiments and are presented as protein expression amounts and redox potential values (Nernst equation).

Jab1 downregulation increases Trx redox potential. MCF-7 cells were seeded to 10-6 in $100 \mathrm{~mm}$ plates. After incubating overnight, cells were incubated with serum-free media for 48 hours. After 48 hour incubation, cells were treated for 30 minutes with $0.1 \%$ DMSO or 100 pg 17ß-estradiol. Cells were harvested in $50 \mathrm{mM}$ guanidine lysis buffer and prepared as described in Materials and Methods. (C) MCF-7 cells were transfected to downregulate Jab1. Cells were then exposed to either $0.1 \%$ DMSO or 100 pg E2 for 30 minutes. Cells were lysed and lysate run through redox western protocol as noted in 
Materials and Methods section. (D) Data are presented as redox potential of thioredoxin. Data shown are representative of three independent experiments and are presented as protein expression amounts and redox potential values (Nernst equation).

Figure 4-MCF7

Oxidation of PTEN by estradiol is reversed with overexpression of thioredoxin reductase. MCF-7 cells overexpressing TrxR1 (erucin pretreat) and TrxR2 (transfection) were treated with $0.1 \%$ DMSO for 20 minutes or $100 \mathrm{pg} 17 \beta$-estradiol for 20 or 30 minutes after 48 -hour incubation in serum-free medium. Cells were harvested as noted in Materials and Methods section. (A) Oxidation of PTEN is shown in EV (control) transfected cells, though not seen in TrxR2 transfected cells. (B) Quantification of oxidized PTEN/reduced PTEN ratio. Data are representative of two independent experiments. 
Figure 5-MCF7

A

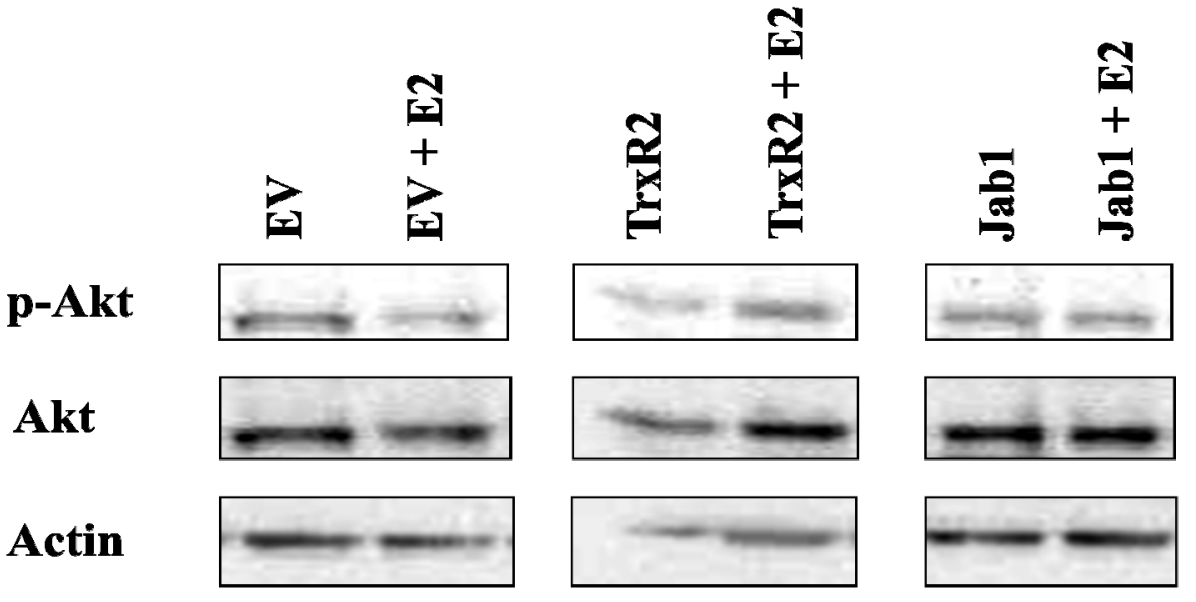

B

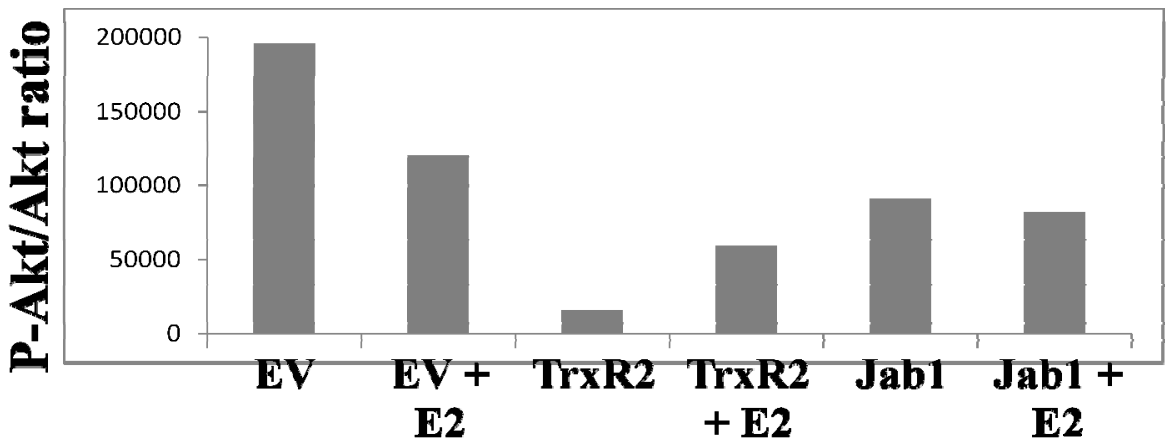

Overexpression of thioredoxin reductase and underexpression of Jab1 decreases

Akt phosphorylation at Ser473 in estrogen-treated MCF-7 cells. Transfected or chemically treated MCF-7 cells were treated with $0.1 \%$ DMSO or 100 pg $17 \beta$-estradiol. (A) Expression of phosphorylated Akt before and after overexpression of TrxR2 or underexpression of Jab1. (B) Quantification of protein expression. E2 time point shown is 30-minute treatment. Akt was normalized to $\beta$-actin first. The graph shown is phosphorylated Akt/total normalized Akt ratio. Data shown are representative of two independent experiments and are presented as protein expression amounts as quantified by densitometry. 
Figure 6-MCF7 


\section{Overexpression of TrxR1 through erucin treatment decreases p27 phosphorylation}

at T157. MCF-7 cells were treated with $0.1 \%$ DMSO or 100 pg $17 \beta$-estradiol. (A) Expression of p27 and phosphorylated p27 at T157 with and without overexpression of TrxR2. (B) Quantification of relative p27 protein expression. (C) Quantification of relative phosphorylated p27 expression. Phosphorylated/total p27 ratio was normalized to $\beta$-actin. (D) Expression of p27 and p27 phosphorylated at T157 after overexpression of TrxR. (E) Quantification of relative p27 protein expression. (F) Quantification of ratio of phosphorylated/total $\mathrm{p} 27$, normalized to $\beta$-actin. Data shown are representative of two independent experiments and are presented as protein expression amounts and redox potential values.

Underexpression of Jab1 decreases p27 phosphorylation at T157. MCF-7 cells were transfected to underexpress Jab2, incubated in serum-free media 48 hours, then treated with $0.1 \%$ DMSO or 100 pg $17 \beta$-estradiol. (A) Expression of phosphorylated p27 at T157 (B) Quantification of protein expression. Phosphorylated/total p27 ratio was normalized to $\beta$-actin. Data shown are representative of two independent experiments and are presented as protein expression amounts and redox potential values.

\section{CONCLUSION}

The purpose of this research was to explore the enigmatic problem of tamoxifen resistance in breast cancer through looking at the p27/Jab1/Trx pathway. The sub goals were twofold: First, to show that reducing oxidized thioredoxin through increasing thioredoxin reductase or that decreasing Jab1 protein can alter p27 phosphorylation; 
second, to show these same cellular alterations can increase tamoxifen sensitivity in previously tamoxifen-resistance breast cancer cells.

Results of this study add several significant findings to research on tamoxifen resistance and the p27/Jab1/Trx pathway. While there is one study that explores glutathione actions on MKP3 phosphatase in antiestrogen resistance, there appear to be no other studies that consider the role of reactive oxygen species in tamoxifen resistance. Further, the studies that involve thioredoxin and chemotherapeutic resistance look at the chemotherapeutics that use a high level of reactive oxygen species to kill breast cancer, and show that thioredoxin interferes with cellular death in these cases. No other study looks at the level of ROS produced by antiestrogens and how thioredoxin alteration by this ROS may affect the possibility of resistance. Findings in this study showed that thioredoxin is oxidized by physiologic levels of estrogen, and that reversal of this oxidation through the overexpression of thioredoxin reductase can lead to previously tamoxifen-resistant cells appearing to regain sensitivity.

There is one study out that shows that p27 and thioredoxin compete for binding to Jab1, and when thioredoxin is not available for binding that Jab1 can bind to p27 and aid in removing it from the nucleus. The current study explored the relationship between these three proteins in tamoxifen-resistant breast cancer cells. While a thioredoxin/Jab1 interaction was shown, $\mathrm{p} 27 / \mathrm{Jab} 1$ binding did not appear to decrease with the reduction of oxidized thioredoxin. In both MCF-7 breast cancer and LCC2 tamoxifen-resistant breast cancer cells, reduction of Jab1 levels led to a change in response of the cells to estrogen 
and tamoxifen, respectively. Decreasing Jab1 led to a decrease in cell growth, a decrease in thioredoxin oxidation, and a decrease in p27 phosphorylation. The role of Jab1 in tamoxifen resistance has not been explored, and as such these data add to the current knowledge.

The current study also sought to explore if the effect thioredoxin has on the PTP PTEN would have downstream effects on the $\mathrm{p} 27$ protein. While PTEN is known to be reduced by thioredoxin, it has not been shown that reducing oxidized thioredoxin through increasing thioredoxin reductase levels affects phosphorylation of p27 at T157. This study shows that in both MCF-7 and LCC2 cells, altering the oxidative state of the cell through thioredoxin reductase can alter the effects on p27 phosphorylated stated. Two phosphorylation sites were shown to be dephosphorylated after an increase in levels of thioredoxin reductase. The PTEN/Akt pathway is implicated in this study, but further studies are recommended, as the time point chosen for experiments may not have been sufficient to show a strong link.

The major goals of this study were to explore a link between oxidative stress and tamoxifen resistance, and specifically to look at the thioredoxin/Jab1/p27 pathway as a target. By identifying the specific data mentioned above, thioredoxin and Jab1 have been shown to be proteins that may play a role in tamoxifen resistance, and through further research may be proven to be potent tools for avoiding antiestrogen resistance in breast cancer. 


\section{Directions for future research}

The results of the present study are intended to start a conversation on the role of thioredoxin reductase, thioredoxin, and Jab1 in antiestrogen resistance. The data show three areas of possible research.

The reduction of oxidized thioredoxin by thioredoxin reductase showed a significant reduction in cell growth and p27 phosphorylation in both MCF-7 cells and tamoxifentreated tamoxifen-resistant LCC2 cells. This effect on cancer cells, as well as the apparent increased sensitivity to tamoxifen, suggest that thioredoxin reductase may be a potent tool in delaying, reducing, or abrogating tamoxifen resistance. This is not true with other chemotherapeutics where thioredoxin can interfere with the onslaught of reactive oxygen species that the chemotherapeutic uses to kill cancer cells. In the case of antiestrogens that have been shown to create ROS but are not seen to use ROS as the main pathway of apoptosis, thioredoxin reductase may prove a useful too, and as such should be explored further in this role.

Jab1 was explored for its role with thioredoxin in counteracting tamoxifen resistance and estrogen effects in MCF-7 cells. The data show that reducing Jab1 can affect tamoxifen sensitivity, causing a decrease in cell growth in tamoxifen-treated tamoxifen-resistant cells. While we were unable to show a change in $\mathrm{p} 27 / \mathrm{Jab} 1$ binding in tamoxifen-treated resistant cells, there was a change in p27 phosphorylation when Jab1 levels were decreased. There was also an interesting finding of an increase in the reduction of thioredoxin when Jab1 was decreased. As such, the p27/Jab1/thioredoxin pathway 
deserves further research to explore other possibilities of interactions between these three proteins, as the final result is decreased growth in both cancer and tamoxifen-resistant cancer cells.

The data in this study show a possible role for thioredoxin in affecting the PTEN/Akt/p27 phosphorylation pathway. As thioredoxin is known to interact with other protein tyrosine phosphatases, these phosphatases should be explored for an effect on antiestrogen resistance. The PTEN pathway deserves further exploration, as our data show minimal results. Other pathways may also show other targets for abrogating antiestrogen resistance.

\section{SUPPLEMENTAL DATA}

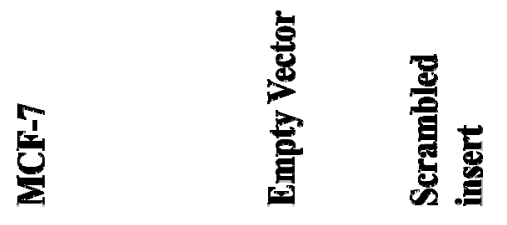

Jab1

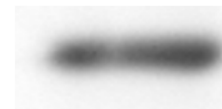

Actin

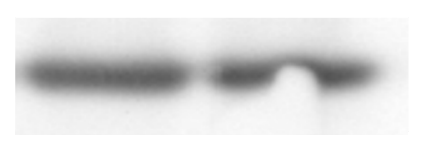

HuSH 29-mer non-effective (scrambled) pRS vector (Origene) was tested and showed similar actions to the empty plasmid vector. 
VITA

\section{ROSALIND BRIGHAM PENNEY}

May 2, 1966

1989

1990

1991-1999

1998-present

1999-2002

2003-2004

2004-2005

2005-2011
Born, Longbranch, New Jersey

B.S., Advertising

University of Florida

Gainesville, Florida

B.S., Therapeutic Recreation

University of Florida

Gainesville, Florida

Activities Director

Leesburg Regional Medical Center Nursing Center

Leesburg, Florida

Business Administrator

Getting Well, Inc.

Orlando, Florida

President

Action Tek, Inc.

Orlando, Florida / Englewood, Florida

Executive Director

Getting Well, Inc.

Orlando, Florida

Administrative Assistant

Rehab Director

Select Medical Rehabilitation Services

Sarasota, Florida

Business Office Manager

The Springs at Lake Pointe Woods

Sarasota, Florida

M.P.H., Environmental Health

Florida International University

Miami, Florida

Ph.D. Candidate, Public Health (Environmental Health)

Florida International University 


\section{PUBLICATIONS AND PRESENTATIONS}

Penney, R. and Roy, D. 2011. Thioredoxin, changes in redox state of cells and a new perspective in an understanding of tamoxifen resistance of breast cancer treatment. Life Sciences, 2011. (Prepared for submission)

Penney, R., Felty, Q., Trevino, F., and Roy, D. 2010. Phytochemical inducers of thioredoxin reductase restore tamoxifen sensitivity in breast resistant cancer cells. Poster presentation, International Conference on Drug Discovery and Therapy, Dubai, UAE. (Submitted)

Penney, R., Felty, Q., and Roy, D. 2010. Erucin treatment through induction of thioredoxin reductase may alter tamoxifen resistance in LCC2 cells. Poster presentation, AACR Annual Meeting, Washington, D.C. (Accepted)

Penney, R., Felty, Q., Slingerland, J, and Roy, D. 2009. Modulation of thioredoxin reductase by sulforaphane may restore tamoxifen sensitivity in resistant LCC2 cells. Poster presentation, SOT PPTOXII, Miami, FL.

Penney, R., Felty, Q., Slingerland, J, and Roy, D. 2009. Redox status contributes to tamoxifen-resistant growth of breast cancer cells. Poster presentation, AACR San Antonio Breast Cancer Symposium, San Antonio, TX.

Penney, R., Felty, Q., Slingerland, J, and Roy, D. 2009. Redox state, thioredoxin-Jab1 interaction and tamoxifen resistance in breast cancer cells. Poster and oral presentations, FIU Breast Cancer Symposium, Miami, FL.

Penney, R., Felty, Q., Slingerland, J., and Roy, D. 2008. Ebselen co-treatment counteracts the effects of antiestrogen on estrogen-induced growth of breast cancer cells as well as restores the growth inhibitory effects of antiestrogen in resistant cells. Poster presentations, Department of Defense Era of Hope Conference, Baltimore, MD, and FIU Breast Cancer Symposium, Miami, FL. 